\title{
PAPEL DA ENZIMA CONVERSORA DE ANGIOTENSINA-I NA REGULAÇÃO HEMATOPOÉTICA DE ANIMAIS NORMAIS E NOCAUTES DOS RECEPTORES B1 DE CININAS
}

\section{CARLOS ROCHA OLIVEIRA}

\author{
Tese (Doutorado) apresentada ao \\ Programa de Pós-Graduação Interunidades \\ Biotecnologia USP/Instituto Butantan/ \\ IPT, para obtenção do Título de Doutor em \\ Biotecnologia.
}


PAPEL DA ENZIMA CONVERSORA DE ANGIOTENSINA-I NA REGULAÇÃO HEMATOPOÉTICA DE ANIMAIS NORMAIS E NOCAUTES DOS RECEPTORES B1 DE CININAS

\section{CARLOS ROCHA OLIVEIRA}

Tese (Doutorado) apresentada ao

Programa de Pós-Graduação Interunidades

Biotecnologia USP/Instituto Butantan/

IPT, para obtenção do Título de Doutor em Biotecnologia.

Área de concentração: Biotecnologia

Orientador: Dra. Claudia Bincoletto Trindade

Co-Orientador: Dr. Ronaldo de Carvalho Araújo 
DADOS DE CATALOGAÇÃO NA PUBLICAÇÃO (CIP)

Serviço de Biblioteca e Informação Biomédica do

Instituto de Ciências Biomédicas da Universidade de São Paulo

(c) reprodução total

Oliveira, Carlos Rocha.

Papel da enzima conversora de angiotensina-I na regulação hematopoética de animais normais e nocautes dos receptores B1 de cininas. / Carlos Rocha Oliveira. -- São Paulo, 2008.

Orientador: Claudia Trindade Bincoletto.

Tese (Doutorado) - Universidade de São Paulo. Instituto de Ciências Biomédicas. Programa de Pós-Graduação Interunidades em Biotecnologia EP/IPT/ICB/Butantan. Área de concentração: Biotecnologia. Linha de pesquisa: Hematopoese.

Versão do título para o inglês: Role of angiotensin-I converting enzyme in the regulation of the hematopoietic response normal and kinin receptor B1 kockout mice.

Descritores: 1. Hematopoese 2. AcSDKP 3. Enzima conversora de angiotensina-I 4. Medula óssea 5. Sistema renina-angiotensina 6 . Sistema calicreína-cininas I. Bincoletto, Claudia Trindade II. Universidade de São Paulo. Instituto de Ciências Biomédicas. Programa de Pós Graduação em Biotecnologia. III. Título. 


\section{UNIVERSIDADE DE SÃO PAULO}

Programa de Pós-Graduação Interunidades em Biotecnologia

Universidade de São Paulo, Instituto Butantan, Instituto de Pesquisas Tecnológicas

Candidato(a): $\quad$ Carlos Oliveira Rocha.

Título da Tese: $\quad$ PAPEL da enzima conversora de angiotensina-I na regulação hematopoética de animais normais e nocautes dos receptores B1 de cininas.

Orientador(a): $\quad$ Claudia Trindade Bincoletto.

A Comissão Julgadora dos trabalhos de Defesa da Tese de Doutorado, em sessão pública realizada a .................., considerou

\section{( ) Aprovado(a) ( ) Reprovado(a)}

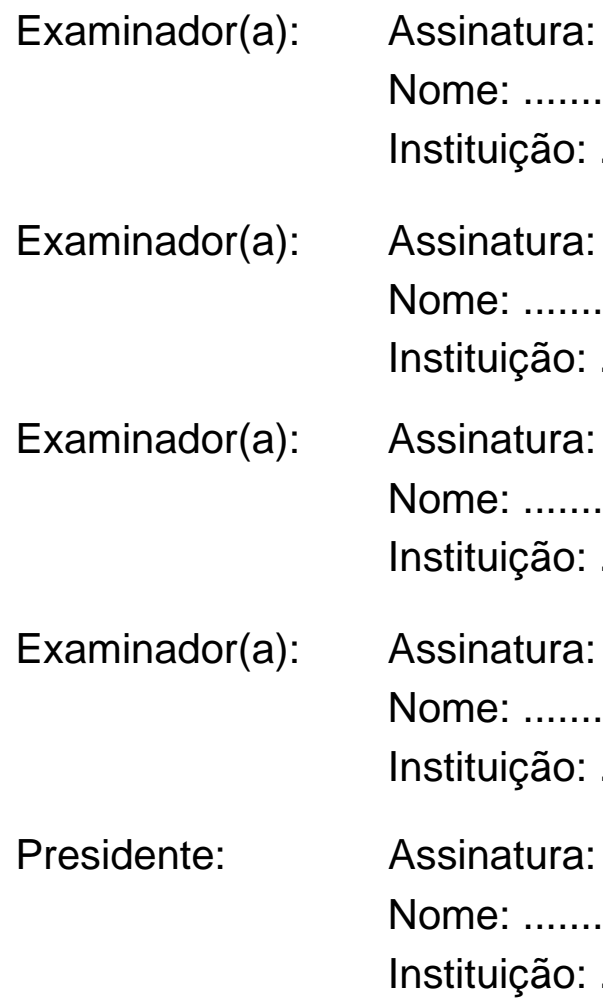




\section{DEDICATÓRIA}

A Deus, força maior que nos alegra e fortalece a cada nascer do sol, na busca do progresso espiritual.

Muito obrigado. 


\section{DEDICATÓRIA}

A Graciane, minha esposa, por todo amor, incentivo e dedicação. Sem sua presença, minha vida, nada teria sentido.

Muito obrigado. 


\section{AGRADECIMENTOS}

À Família, sempre presente, vibrante e atuante.

À professora Dra. Claudia Bincoletto, a quem agradeço por tudo que aprendi até aqui, mas principalmente, por me ensinar que vale sim, e muito, nos dedicarmos e agirmos de maneira correta frente aos nossos ideais.

Ao professor Dr. Ronaldo de Carvalho Araújo. Grande Mestre. Muito obrigado por tudo, pela ajuda, pelo aprendizado, pelo apoio desde o primeiro contato, ainda em Mogi, até hoje e principalmente pela amizade.

Ao professor Dr. João Bosco Pesquero, pelo grande apoio material neste trabalho.

Ao professor Dr. Ivarne Luis Santos Tersariol, pela grande ajuda na realização deste trabalho, pelas dicas e pelo incentivo.

À professora Dra. Alice Teixeira, pelo apoio material neste trabalho.

A todos os amigos da Biofísica da UNIFESP, em especial: Felipe Castellani, João Daivison, Elice, Edgar Julian, Juliana, Raphael e Anderson. Obrigado por toda a ajuda prestada e principalmente pela convivência.

Ao grande amigo Christiano, por todo o período de intensa convivência e por todo período que mesmo à distância me orientava e aconselhava a respeito das culturas celulares. Graças a sua amizade e solidariedade cheguei até aqui. Continue assim amigo, ético, honesto e acima de tudo, amigo daqueles que por você torcem. Todas as palavras aqui são insuficientes para Ihe agradecer! Este trabalho também é seu! Grande abraço Amigo!

Ao querido amigo Marcos Luengo Blanco, pois se cheguei até este momento, é porque tive e tenho em você uns dos raros amigos que levo no coração. Obrigado pelo início de tudo, ainda no CELF e depois na UNICAMP, nunca esquecerei da sua ajuda. Celebremos nossa amizade!

Ao Dr. Neivaldo, homem de princípios, além de amigo. Continue assim, um exemplo de caráter e dedicação.

A Dra. Claudia Marques e a Dra. Edith Marques, por me fazerem voltar a sorrir!

Ao pessoal de Mogi, Flávia Enira, Bruno, Dr. Maurício, Douglas, Paulo, Taíz e Cecília.

À Cleomar Azevedo, minha tia, sem a qual nada disso teria acontecido. Inspiração na minha vida adulta. Muito obrigado! 
Aos animais envolvidos neste trabalho, centelhas de luz que certamente caminham em direção ao progresso. E para aqueles que não participaram da elaboração da tese, mas que ajudaram muito com sua fiel capacidade de amar, fica aqui minha gratidão, seja pelo amor de um cãozinho, seja pelo amor de um gatinho.

Ao Instituto de Ciências Biomédicas-IV da USP e a Universidade de Mogi das Cruzes, por todo aprendizado teórico e pratico.

À Fundação de Amparo à Pesquisa do Estado de São Paulo (FAPESP) pelo apoio financeiro.

E a todos aqueles que não foram citados, mas que foram importantíssimos para a realização deste trabalho. 
"Na vida, não vale tanto o que temos nem tanto importa o que somos.

Vale o que realizamos com aquilo que possuímos e, acima de tudo, importa o que fazemos de nós".

\section{Emmanuel}




\section{RESUMO}

OLIVEIRA, C.R. Papel da enzima conversora de angiotensina-I na regulação hematopoética de animais normais e nocautes dos receptores B1 de cininas. 2008. 106 f. Tese (Doutorado em Biotecnologia) - Instituto de Ciências Biomédicas, Universidade de São Paulo, São Paulo, 2008.

A enzima conversora de angiotensina-I (ECA) é um elemento chave tanto do sistema renina angiotensina (SRA) assim como do sistema calicreína-cininas (SCC). Recentemente trabalhos na literatura demonstraram a existência de um SRA ativo na medula óssea, sugerindo assim, uma possível participação da ECA sobre a resposta hematopoética. Assim, avaliamos a participação da ECA na regulação hematopoética de animais não modificados (WT) e nocautes dos receptores B1 de cininas (KOB1), utilizando para isto ensaios clonogênicos em soft-ágar, para avaliarmos o crescimento e diferenciação de granulócitos e macrófagos (CFU-GM) e o sistema de cultura líquida de longa duração (CLLD). Os resultados obtidos através de microscopia confocal e citometria de fluxo com dupla marcação indicaram a presença da ECA em células estromais das CLLD. A análise do ciclo celular e a quantificação de CFU-GM mostraram a possível participação da ECA na proliferação de progenitores hematopoéticos, possivelmente através do controle dos níveis de AcSDKP, pois o tratamento com o tetrapeptídeo e com captopril, aumentou significativamente o número de precusores hematopoéticos em fase $S$ e reduziu, também significativamente, o número de CFU-GM in vitro e in vivo. Quando adicionado às CLLD, o AcSDKP foi capaz de alterar a expressão do mRNA da ECA. Em relação aos animais KOB1, os resultados mostraram maior atividade da ECA, acompanhado de aumento não significativo da expressão gênica e protéica da enzima. O tratamento das CLLD de animais WT com agonistas de receptores de cininas, não alterou a expressão gênica e a atividade da ECA. Assim, nossos dados sugerem que a ECA participa da regulação hematopoética neste modelo. No entanto, novos estudos serão necessários para a elucidação dos mecanismos envolvidos na expressão e/ou controle da atividade da ECA pelos receptores de cininas.

Palavras-chave: Hematopoese. AcSDKP. Enzima conversora de angiotensina. Cininas. Sistema renina-angiotensina. Sistema calicreína-cininas 


\section{ABSTRACT}

OLIVEIRA, C.R. Role of angiotensin-I converting enzyme in the regulation of hematopoietic response in normal and kinin receptor B1 kockout mice. 2008. 106 f. Doctor thesis (Biotechnology) - Instituto de Ciências Biomédicas, Universidade de São Paulo, São Paulo, 2008.

Evidences on the presence of the renin angiotensin system in the bone marrow and the possible participation of the angiotensin-I converting enzyme (ACE) in the hematopoietic regulation have aroused interest of the scientific community. As the ACE also is a common element of the kallikrein-kinin system (KKS), it is possible that elements of KKS, can be involved in the hematopoietic control. Thus, we evaluated the participation of the ACE on the hematopoietic regulation of wild-type (WT) and kinin receptor $\mathrm{B} 1$ knockout mice (KOB1). For this, we use techniques of bone marrow cell culture, including the clonogenic assays for granulocyte-macrophage (GM-CFU) and the long term bone marrow cultures (LTBMC). The results obtained with flow cytometry double labeling has been shown that ACE is present, in stromal cells from LTBMC and the cell cycle analysis and the GM-CFU number indicated its possible participation on hematopoietic proliferation through the control of AcSDKP levels, therefore the treatment with AcSDKP and captopril, decreased significantly the GMCFU number in vitro and in vivo. When added to the LTBMC, the AcSDKP altered significantly the expression of ACE mRNA, suggesting that its levels could control the gene expression of this enzyme. In relation to KOB1 mice, the results has been shown increase of the ACE activity and not significant increase of the gene and protein expression of the enzyme. The treatment of the LTBMC from WT mice with kinins receptors agonists, did not modify the gene expression and the ACE activity. Thus, our results suggest that ACE participates of the hematopoietic regulation in this model. However, new studies will be necessary to understand the involved mechanisms in the expression and/or control of ACE activity by kinins receptors.

Key-words: Hematopoiesis. AcSDKP. Angiotensin-I converting enzyme. Kinins. Renin-angiotensin system. Kallikrein-kinin system. 


\section{LISTA DE ILUSTRAÇÕES}

Figura 1: Representação esquemática da divisão hierárquica das células que compõem o sistema hematopoético de um indivíduo adulto.

Figura 2: Representação esquemática da ativação do sistema calicreínacininas

Figura 3: Representação esquemática da relação entre atividade da ECA (cininase II) e os sistemas renina-angotensina e calicreína-cininas.

Figura 4: Aspecto microscópico de colônias de granulócitos e macrófagos (CFU-GM) obtidas da medula óssea de camundongos (aumento 400x).

Figura 5: Mensuração das fases do ciclo celular. Histograma do conteúdo de DNA por "syto-green" é lido no detector FL1 em células de CLLD.

Figura 6: (A) Localização da ECA em CLLD de camundongos WT. Fotomicrografia de fluorescência confocal de células de CLLD imunomarcadas com anticorpo imunoespecífico anti-ECA. (B) Imagem de autofluorescência controle da fluorescência.

Figura 7: Expressão relativa do mRNA da ECA em unidades arbitrárias a partir da medula óssea e de CLLD obtidas a partir de células da medula óssea de animais WT.

Figura 8: Atividade da ECA em células da medula óssea e em CLLD obtidas a partir de células da medula óssea de animais WT...

Figura 9: Número de células não-aderentes (viáveis) obtidas nas $5^{a}$ e $6^{a}$ semanas, a partir do sobrenadante das CLLD obtidas a partir de células da medula óssea de animais WT e tratadas com AcSDKP (1nM).

Figura 10: Efeito dos compostos AcSDKP $(1 \eta \mathrm{M})$ e captopril $(1 \mu \mathrm{M})$ nas células aderentes dos estromas das CLLD. Avaliação realizada na $6^{a}$ semana de cultivo

Figura 11: Efeito do AcSDKP (1nM) na formação de CFU-GM a partir das células não-aderentes presentes no sobrenadante das CLLD obtidas de células da medula óssea de animais WT. Avaliação iniciada na $5^{\mathrm{a}}$ semana de cultivo......

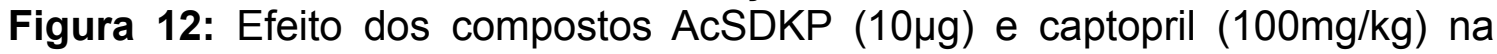
formação de colônias de precursores hematopoéticos para granulócitos e macrófagos (CFU-GM) obtidos a partir de células da medula óssea de animais WT submetidos ao tratamento por via subcutânea $(n=5)$...

Figura 13: Expressão relativa do mRNA da ECA em unidades arbitrárias a partir de CLLD obtidas a partir da medula óssea de camundongos WT. O tratamento com as diferentes concentrações de AcSDKP aumentaram significativamente os níveis de mRNA da ECA nas culturas.

Figura 14: (A) Expressão relativa do mRNA dos receptores de cininas B1 e B2 em unidades arbitrárias na medula óssea de camundongos WT. (B) Expressão relativa do mRNA dos receptores de cininas $B 1$ e $B 2$ em unidades arbitrárias das CLLD obtidas a partir de células da medula óssea de camundongos WT......

Figura 15: Atividade da ECA nas culturas líquidas de longa duração. A atividade enzimática foi determinada espectrofluorimetricamente no final da $4^{\mathrm{a}}$ semana de cultura na presença dos compostos Lys-bradicinina (LBK) e des-Arg ${ }^{9}$ bradicinina (DBK). 
Figura 16: Expressão relativa do mRNA da ECA em unidades arbitrárias a partir da medula óssea de camundongos WT. O tratamento com DBK e LBK não alterou os níveis de mRNA da enzima.

Figura 17: (A) Western blotting das proteínas isoladas de homogenato celular das CLLD de animais WT e KOB1. As proteínas foram separadas por SDS/PAGE (gel a 7,5\%), transferidas para uma membrana de nitrocelulose e reveladas com anticorpo monoclonal contra ECA. (B) Densidade ótica relativa das bandas, entre a ECA e $\beta$-actina. Os resultados foram obtidos através do software LABWORKS. (C) Expressão relativa do mRNA da ECA em unidades arbitrárias em CLLD de animais WT e KOB1

Figura 18: Histograma da análise de células da medula óssea de animais WT e KOB1 que foram submetidas à imunofenotipagem e marcadas simultaneamente com anti-ECA murino. As células da medula óssea foram coletadas e usados os seguintes marcadores de superfície: CD45 e Ter119. Não houve diferença significativa entre os animais WT e KOB1em relação à expressão da ECA.

Figura 19: (A) e (B) Número de células não-aderentes (viáveis) obtidas nas $5^{a}$ e $6^{a}$ semanas, a partir do sobrenadante das culturas líquidas obtidas de células da medula óssea de animais WT e KOB1, respectivamente e tratadas com AcSDKP $(1 \eta \mathrm{M})$ e captopril $(1 \mu \mathrm{M})$. (C) Comparativo da $5^{\mathrm{a}}$ semana

Figura 20: Efeito dos compostos AcSDKP $(1 \eta M)$ e captopril $(1 \mu \mathrm{M})$ nas células aderentes dos estromas das CLLD. Avaliação realizada na $6^{\text {a }}$ semana de cultivo

Figura 21: Efeito dos compostos AcSDKP (1ПM) e captopril $(1 \mu \mathrm{M})$ na formação de colônias de precursores hematopoéticos para granulócitos e macrófagos (CFU-GM) obtidas a partir das células não-aderentes presentes no sobrenadante das culturas líquidas. Avaliação iniciada na $5^{\mathrm{a}}$ semana de cultura.

(A) Animais KOB1. (B) Animais WT.

Figura 22: Análise da porcentagem de progenitores hematopoéticos nas CLLD de animais WT e KOB1. As células da medula óssea foram coletadas e os seguintes marcadores de superfície utilizados: Gr1, Mac1 e Ter119.

Figura 23: Histogramas da análise de progenitores hematopoéticos nas CLLD nas CLLD de animais WT, KOB1 e KOB1 tratadas com captopril. Foram utilizados os seguintes marcadores de superfície: Gr1, Mac1 e Ter119.

Figura 24: Análise das células-tronco de longa e curta duração nas CLLD de animais WT, KOB1 e KOB1 tratadas com captopril. Para a imunofenotipagem foram utilizados os seguintes marcadores de superfície: C-Kit e Sca-1...

Figura 25: Histogramas da análise de células-tronco de longa e curta duração nas CLLD de animais WT, KOB1 e KOB1 tratadas com captopril. Para a imunofenotipagem foram utilizados os seguintes marcadores de superfície: CKit e Sca-1.

Figura 26: (A) Atividade da ECA nas CLLD tratadas com salina, AcSDKP (1nM) e captopril $(1 \mu \mathrm{M})$. (B) Expressão relativa do mRNA da ECA em unidades arbitrárias a partir de CLLD obtidas de medula óssea de camundongos WT e KOB1

Figura 27: Curva padrão para determinação das concentrações de AcSDKP no meio condicionado das CLLD submetidas aos diferentes tratamentos.

Figura 28: Níveis de AcSDKP no meio condicionado das CLLD de animais WT e KOB1. O tratamento das culturas foi realizado semanalmente juntamente com a troca por meio fresco. As culturas foram tratadas com salina e captopril $(1 \mu \mathrm{M})$. 
Figura 29: Efeito do AcSDKP (1 $\eta \mathrm{M})$ e do captopril $(1 \mu \mathrm{M})$ na porcentagem de células (c-kit ${ }^{+} \mathrm{Gr}^{-} \mathrm{Mac1}^{-}$) em fase $\mathrm{S}$ do ciclo celular nas CLLD...

Figura 30: Histogramas do conteúdo de DNA por "syto-green". Leitura realizada no detector FL1. Células de CLLD de animais WT e KOB1 tratadas com AcSDKP, $(1 \eta \mathrm{M})$, captopril $(1 \mu \mathrm{M})$ e salina (controle).

Figura 31: Efeito dos compostos AcSDKP $(10 \mu \mathrm{g})$ e captopril $(100 \mathrm{mg} / \mathrm{kg}) \mathrm{na}$ formação de colônias de precursores hematopoéticos para granulócitos e macrófagos (CFU-GM) da medula óssea de animais WT e KOB1 submetidos ao tratamento $(n=5)$. 


\section{LISTA DE TABELAS}

Tabela 1: Número de células não-aderentes (viáveis) obtido na $5^{\mathrm{a}}$ e $6^{\mathrm{a}}$ semanas de cultivo e coletadas do sobrenadante das CLLD obtidas a partir de células da medula óssea de animais WT $(n=5)$. As culturas foram tratadas com AcSDKP $(1 \eta M)$ e captopril $(1 \mu \mathrm{M})$.....

Tabela 2: Número de células não-aderentes (viáveis) obtido na $5^{\mathrm{a}}$ e $6^{\mathrm{a}}$ semanas de cultivo e coletadas do sobrenadante das CLLD obtidas a partir de células da medula óssea de animais $\operatorname{KOB} 1(n=5)$. As culturas foram tratadas com AcSDKP ( 1 ПM) e captopril $(1 \mu \mathrm{M})$.

Tabela 3. Número de CFU-GM obtido do sobrenadante das culturas líquidas de longa duração de animais WT e tratadas semanalmente com AcSDKP $(1 \cap \mathrm{M})$ e captopril $(1 \mu \mathrm{M})$

Tabela 4. Número de CFU-GM obtido do sobrenadante das culturas líquidas de longa duração de animais KOB1 e tratadas semanalmente com AcSDKP $(1 \eta M)$ e captopril $(1 \mu \mathrm{M})$

Tabela 5: Níveis de AcSDKP no meio condicionado de culturas de longa duração tratadas com salina (controle)...

Tabela 6: Níveis de AcSDKP no meio condicionado de CLLD tratadas com captopril $(1 \mu \mathrm{M})$.

Tabela 7: Lista dos conjuntos de sondas e primers utilizados na reação de RTPCR em tempo real. 


\section{LISTA DE ABREVIATURAS E SIGLAS}

\begin{tabular}{|c|c|}
\hline AcSDKP & N-Acetyl-seryl-aspartyl-lysyl-proline \\
\hline AT1 & Receptor tipo I de angiotensina II \\
\hline BFU-E & Unidades formadoras de blastos de eritrócitos \\
\hline c-DNA & DNA complementar \\
\hline CFU-GM & Unidade formadora de colônia para granulócito-macrófago \\
\hline CFU-mix & $\begin{array}{l}\text { Unidades formadoras de colônias misturadas (granulócitos } \\
\text { e macrófagos) }\end{array}$ \\
\hline DBK & Des-Arg ${ }^{9}$ bradicinina \\
\hline DEPC & Dietilpirocarbonato \\
\hline DMEM & Dulbecco's Modified Eagle's Medium \\
\hline dNTP & Desoxirribonucleotídeo tri-fosfato \\
\hline G-CSF & Fator estimulador de colônia para granulócitos \\
\hline GM-CSF & Fator estimulador para colônias de granulócitos-macrófagos \\
\hline HSC & Célula tronco hematopética \\
\hline LBK & Lys-bradicinina \\
\hline M-MLV & Vírus da leucemia murina Moloney \\
\hline mRNA & RNA mensageiro \\
\hline rGM-CSF & GM-CSF recombinante \\
\hline RNA & Ácido ribonucléico \\
\hline RT & Retrotranscrição \\
\hline TGF- $\beta$ & Fator de crescimento transformador- $\beta$ \\
\hline VCAM-1 & Molécula de adesão de célula vascular-1 \\
\hline VLA-4 e VLA-5 & Very late antigen group \\
\hline a-MEM & Meio Dulbecco's alfa-modificado \\
\hline
\end{tabular}




\section{SUMÁRIO}

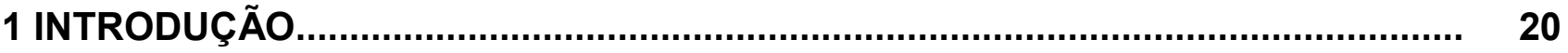

1.1 A hematopoese................................................................................... 20

1.1.1 O microambiente hematopoético............................................................. 21

1.2 Sistema renina-angiotensina (SRA) e medula óssea....................................... 24

1.3 Sistema calicreína-cininas (SCC)................................................................. 27

1.3.1 Receptores de cininas............................................................................ 29

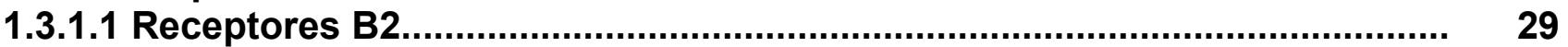

1.3.1.2 Receptores B1 .................................................................................. 30

1.3.1.3 Medula óssea e sistema calicreína-cininas (SCC)..................................... 31

1.4 Interação entre os sistemas calicerína-cininas e renia-angiotensina............... 32

2 OBJETIVOS............................................................................................ 35

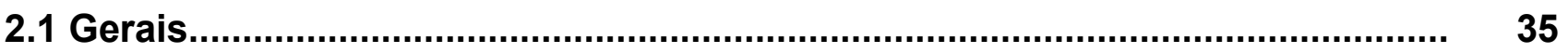

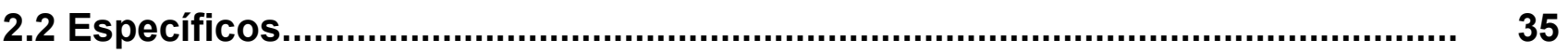

2.2.1 Estudos in vitro....................................................................................... 35

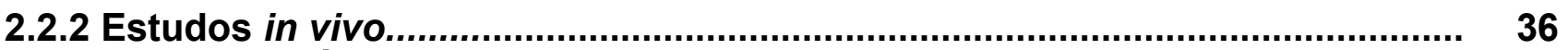

3 MATERIAL E MÉTODOS............................................................................ 37

3.1 Compostos químicos...................................................................................... 37

3. 1.1 Captopril e ACSDKP ……....................................................................... 37

3.1.2 Substrato fluorogênico da ECA (Abz-YRK(Dnp)P-OH.................................. 37

3.1.3 DBK (Des-Arg ${ }^{9}$ bradicinina) e LBK (Lys-bradicinina)..................................... 37

3.2 Animais........................................................................................... 37

3.2.1 Animais nocautes KOB1 ................................................................... 37

3.2.2 Tratamento dos animais WT e KOB1 .......................................................... 38

3.3 Técnicas de cultivo celular............................................................................ 38

3.3.1 Cultura de líquida de longa duração............................................................ 38

3.3.1.1 Ensaio clonogênico em soft-ágar de progenitores hematopoéticos para granulócitos e macrófagos (CFU-GM) a partir de células sobrenadantes das

CLLD.

3.3.2 Ensaio clonogênico em soft-ágar de progenitores hematopoiéticos para granulócitos e macrófagos (CFU-GM) a partir de células da medula óssea de animais WT e KOB1 tratados com AcSDKP e captopril.

3.3.3 Cocultura de células hematopoéticas mononucleares para

imunofenotipagem e análise do ciclo celular..

3.3.3.1 Imunofenotipagem de células hematopoéticas obtidas das coculturas e tratadas com captopril.

3.3.4 Avaliação do ciclo celular de células hematopoéticas obtidas das

coculturas tratadas com AcSDKP e captopril.

3.4 Determinação da atividade da ECA nas CLLD tratadas com AcSDKP, captopril, DBK e LBK

3.5 Avaliação da expressão gênica da ECA e de receptores B1 e B2 de cininas nas CLLD e na medula óssea de animais WT e KOB1, através de RT-PCR em tempo real.

3.6 Dosagem de AcSDKP no sobrenadante e nas células presentes no sobrenadante das CLLD.

3.7 Microscopia confocal.

3.8 Western blotting. 


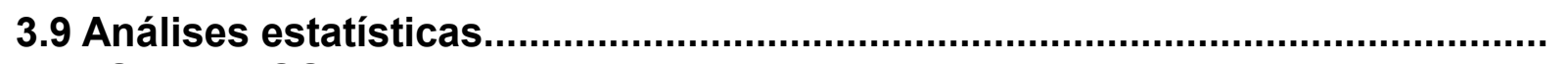

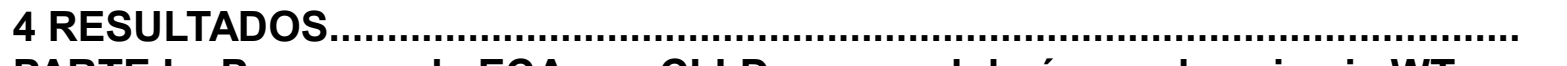

PARTE I - Presença da ECA nas CLLD e na medula óssea de animais WT...........

4.1 Microscopia confocal.

4.2 Avaliação da expressão gênica da ECA nas CLLD e na medula óssea de animais WT através de RT-PCR em tempo real.

4.3 Avaliação da atividade enzimática da ECA nas CLLD e na medula óssea dos animais WT.

PARTE II - Papel do AcSDKP na regulação hematopética e modulação da expressão gênica da ECA.

4.4 Tratamento das CLLD com AcSDKP e captopril e realização de ensaios clonogênicos em soft-ágar a partir de células sobrenadantes das CLLD.............. 4.5 Ensaio clonogênico em soft-ágar a partir de células obtidas da medula óssea de animais WT tratados com AcSDKP e captopril.

4.6 Avaliação da expressão gênica da ECA através de RT-PCR em tempo real nas CLLD tratadas com ACSDKP.

PARTE III - Presença dos receptores B1 e B2 e influência dos agonistas DBK e LBK na atividade enzimática e expressão gênica da ECA.

4.7. Avaliação da expressão gênica dos receptores $B 1$ e $B 2$ de cininas através de RT-PCR em tempo real na medula óssea e nas CLLD de animais WT.. 4.8 Influência do tratamento das CLLD de animais WT com DBK e LBK.................. PARTE IV - Papel da ECA na regulação hematopoética das CLLD de animais nocautes dos receptores $B 1$ de cininas.

4.9 Expressão gênica e protéica da ECA nas CLLD obtidas de células da medula óssea de animais WT e KOB1 através de RT-PCR em tempo real e western blotting....

4.10 Imunofenotipagem de células da medula óssea de animais WT e KOB1 e determinação das populações que expressam a ECA.

4.11 Influência do tratamento das CLLD obtidas de células da medula óssea de animais KOB1 com AcSDKP e captopril.

4.12 Ensaios clonogênicos em soft-ágar a partir de células obtidas do sobrenadante das CLLD de animais WT e KOB1 e tratadas com AcSDKP e captopril.

4.13 Imunofenotipagem de células das CLLD obtidas da medula óssea de animais WT e KOB1 e a influência do tratamento com captopril sobre as CLLD de animais KOB1

4.14 Influência do tratamento com AcSDKP e captopril na atividade e expressão gênica da ECA nas CLLD de animais KOB1 e WT.

4.15 Quantificação dos níveis de AcSDKP nas CLLD obtidas da medula óssea de animais WT e KOB1 e tratadas com captopril.

4.16 Influência dos compostos AcSDKP e captopril sobre o ciclo celular de células sobrenadantes das CLLD de animais WT e KOB1.

4.17 Ensaio clonogênico em soft-agar a partir de células obtidas da medula óssea de animais WT e KOB1 tratados com AcSDKP e captopril.

5 DISCUSSÃO.

6 CONCLUSÃO

REFERÉNCIAS BIBLIOGRÁFICAS

APÊNDICE. 


\section{INTRODUÇÃO}

\subsection{A hematopoese}

A hematopoese é o processo de produção de células sangüíneas. Na fase adulta, este fenômeno é estabelecido na medula óssea e compreende dois eventos distintos: a linfopoese (linfócitos B, T e células NK) e a mielopoese (granulócitos, monócitos, eritrócitos e megacariócitos), contudo, todas estas células se originam a partir de um progenitor comum, indiferenciado, denominado célula-tronco hematopoética (OGAWA, 1993) (Figura 1). Os eventos de proliferação, diferenciação, quiescência e apoptose do sistema hematopoético são controlados por diversos mediadores, dentre eles, citocinas, elementos de matriz extracelular, moléculas de adesão, fatores de transcrição, além da estreita associação com as células estromais (WHETTON e SPOONCER, 1998).

As citocinas, por exemplo, podem estar associadas a células e/ou à matriz extracelular do microambiente medular. Uma mesma citocina pode ter efeitos opostos dependendo do grau de diferenciação celular. Algumas, sozinhas, não induzem respostas, tendo efeito somente quando em sinergia com outras citocinas (VERFAILLIE, 1998).

Além dos fatores solúveis, as moléculas de adesão, principalmente as integrinas presentes nas células-tronco hematopoéticas, como VLA-4 e VLA-5, que se ligam a VCAM-1 em células estromais, ou a componentes de matriz extracelular como fibronectina, são essenciais na regulação da hematopoese (COULOMBEL et al., 1997). As moléculas de adesão são também responsáveis juntamente com as quimiocinas, de mediar o processo de retenção das células hematopoéticas na cavidade medular, uma vez que foi demonstrado que na ausência do receptor para SDF-1a (stromal cell-derived factor-1alpha), os precursores de linfócitos B e mielóides migram para periferia (HIDALGO et al., 2001). Aliado a isso, elementos de matriz extracelular, como colágeno, laminina, fibronectina, tenascina e proteoglicanos também possuem relevância sobre a modulação da resposta hematopoética. A estrutura fina de glicosaminoglicanos sulfatados, como heparam sulfato, pode ser um componente estrutural e funcional importante neste sistema, 
sendo estes, capazes de modular a diferenciação das células hematopoéticas via estímulo justácrino (GUPTA et al., 1998).

O controle na produção de células progenitoras é mantido através da taxa de diferenciação, proliferação e maturação de células diferenciadas e também através da morte das células hematopoéticas maduras, incluindo células do estroma medular (DENNIS e CHARBORD, 2002). Esta regulação ocorre principalmente via interação célula-célula e também através da produção de citocinas específicas (MCNIECE e BRIDDELL, 2001).
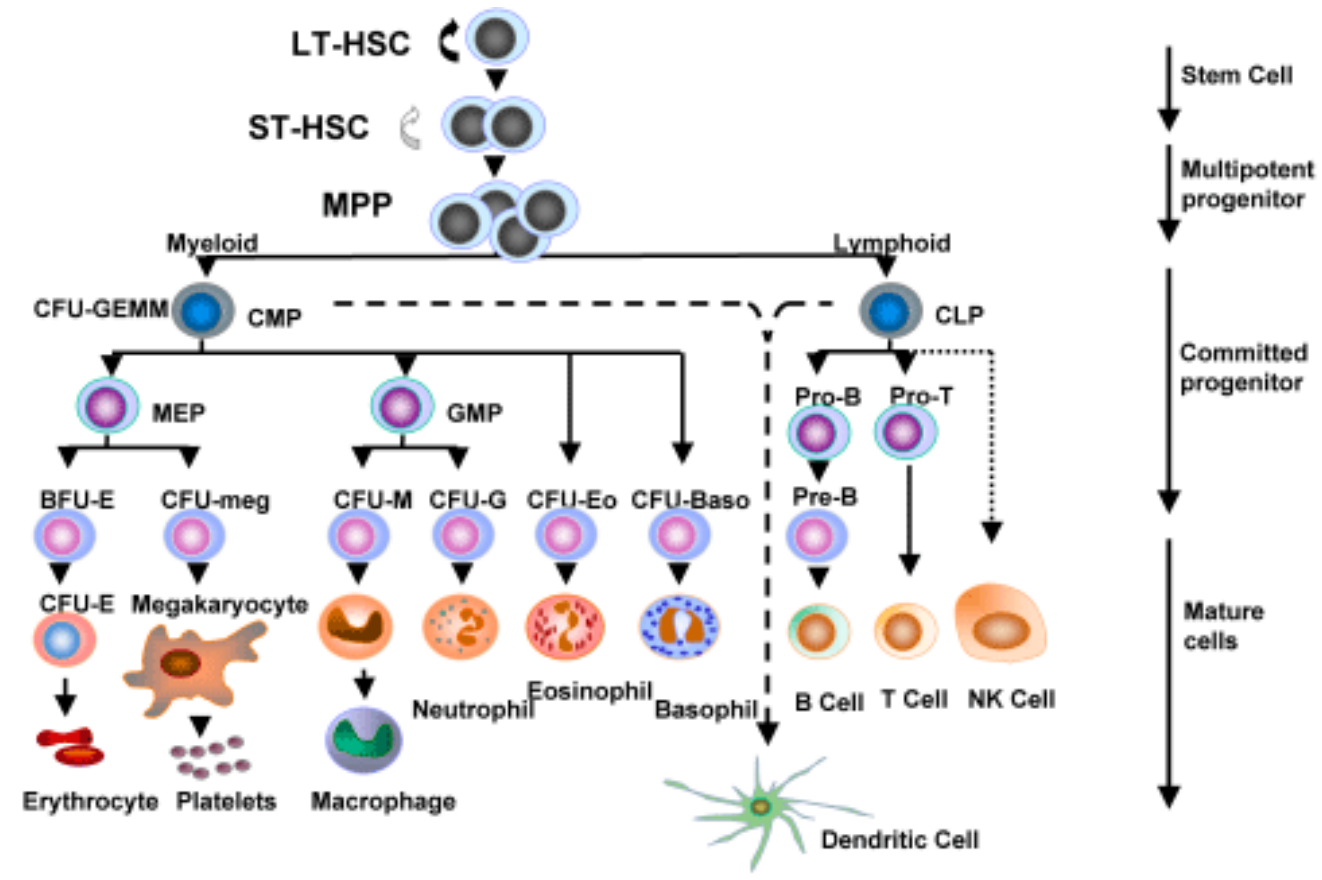

Figura 1 - Representação esquemática da divisão hierárquica das células que compõem o sistema hematopoético de um indivíduo adulto. Adaptado de Karlsson S. Disponível em: <http://www.molmed.lu.se/hematopoiesis_p00.htm>. Acesso em: 03 mar. 2008.

\subsubsection{O microambiente hematopoético}

$\mathrm{Na}$ medula óssea, a hematopoese é associada ao estroma medular. Este microambiente é representado por células de tecido conjuntivo, as quais são responsáveis por fornecer suporte estrutural e molecular ao sistema hematopoético. Desta forma, o termo célula estromal é um termo genérico, que se refere às células 
teciduais que formam o microambiente hematopoético (DORSHKIND, 1990). Nesta população celular heterogênea, encontram-se as células endoteliais, fibroblastos, adipócitos, células reticulares, osteoblastos e células-tronco mesenquimais (BIANCO et al., 2001). As células estromais são fontes de citocinas, glicoproteínas e glicosaminoglicanos, dentre outros fatores. Diferentes combinações destes fatores levam a formação de microambientes específicos dentro da cavidade medular, resultando na distribuição ordenada das células hematopoéticas em diferentes estágios de diferenciação (WEISS e GEDULDIG, 1991).

Em 1977, Dexter e colaboradores perceberam que a manutenção das populações hematopoéticas mais primitivas, bem como os eventos de proliferação e diferenciação celulares, exigia a formação de uma camada de células aderentes representativas do microambiente medular, denominado estroma hematopoético. Este achado foi possível graças ao desenvolvimento do modelo de cultivo in vitro de longa duração, descrito acima.

A necessidade do contato direto entre os precursores pluripotentes e o estroma hematopoético para a sustentação da hematopoese, observado por Dexter et al. (1979), sugere que além dos constituintes da membrana das células do estroma, a matriz extracelular também é um importante mediador envolvido no comportamento das células pluripotentes.

Alguns anos depois, Bentley e Tralka (1983) mostraram a necessidade de um contato íntimo entre os precursores pluripotentes e o estroma hematopoético. $\mathrm{Na}$ ausência deste contato, os precursores não tinham acesso aos sinais regulatórios expressos pelas células do estroma. Além disso, o tecido medular também é capaz de secretar fatores solúveis que conferem manutenção, sobrevivência, proliferação, diferenciação e auto-renovação das células tronco hematopoéticas (FIBBE et al., 1988; EAVES et al., 1991; HERMAN et al., 1998).

Atualmente, sabe-se que as células estromais influenciam o desenvolvimento das células hematopoéticas através da produção de citocinas e também por sinais mediados pelo contato direto das células progenitoras. Tanto a fibronectina como outras moléculas de adesão foram identificadas componentes necessários para a adesão de progenitores as células estromais (VERFAILLIE et al., 1991; MIYAKE et al., 1991; KINCADE, 1992; RYAN, 1993; KINASHI et al., 1994; VERFAILLIE, 1998; HUSS, 2000; HUYGEN et al., 2002). Além disso, outros componentes como o 
colágeno do tipo I e III (BENTLEY et al., 1984), a laminina (ZUCKERMAN e WICHA, 1983; VERFAILLIE, 1998; GU et al., 1999), a hemonectina (PETERS et al., 1990), proteoglicanos e glicosaminoglicanos (GALLAGHER et al., 1986; DRZENIEK et al., 1997), são depositados pelas células estromais no espaço extracelular. Todas essas moléculas participam de fenômenos que envolvem desde a simples adesão celular até os complexos mecanismos de proliferação e diferenciação celulares. Por isso, as células estromais, participam integralmente da rede reguladora no microambiente da medula óssea (TRENTIN, 1970; TAICHMAN et al., 2000).

É importante mencionarmos que estas células também são sensíveis a fatores regulatórios extrínsecos. Por exemplo, hormônios esteróides e citocinas produzidas por células do sistema imunológico também podem alterar a produção da matriz extracelular (BRADLEY, 1966; ICHIKAWA, 1966; TRENTIN, 1970; PARCHMENT 1993). Neste sentido, dentre os principais fatores que modulam o "steady-state" de células estromais, podemos citar o fator de crescimento derivado de plaquetas (PDGF), o fator de crescimento de fibroblastos (FGF) e o fator estimulante de colônia de macrófagos (M-CSF) (DELDAR e STEVENS, 1993; DELDAR, 1994; DELDAR et al., 1995).

Além dos mecanismos endógenos envolvidos no controle da hematopoese, vários outros fatores controlam a expressão das moléculas de adesão e a atividade de seus ligantes, como por exemplo, a exposição destas células a diferentes compostos químicos.

Atualmente, vários autores sugerem que a hematopoese apresenta uma complexidade muito maior daquela imaginada nesta última década. Neste sentido, recentemente verificou-se a presença do sistema renina-angiotensina (SRA) e conseqüentemente a presença de cininases envolvidas no seu controle, como por exemplo, a enzima conversora de angiotensina-I (ECA), provavelmente produzida por macrófagos pertencentes ao estroma medular (HAZNEDAROGLU, 1996; HAZNEDAROGLU e OZTURK, 2003). Segundo Abali (2002) o SRA participa da resposta hematopoética controlando importantes funções biológicas e patológicas de maneira parácrina e/ou autócrina. 


\subsection{Sistema renina-angiotensina (SRA) e medula óssea}

O SRA foi intensamente estudado como um sistema circulante endócrino diretamente envolvido na liberação de aldosterona e na produção de angiotensina II. A liberação de renina é estimulada pela redução da pressão arterial renal, estimulação simpática e diminuição do aporte de sódio ou aumento da concentração do mesmo no túbulo renal distal. A renina atua sobre o angiotensinogênio, clivando o decapeptídio inativo, a angiotensina I. A seguir, este decapeptídio é convertido pela enzima conversora de angiotensina (ECA) em angiotensina II (RIORDAN, 2003). Em locais específicos, a angiotensina II pode ser convertida em angiotensina III pela enzima glutamil aminopeptidase, como no caso do cérebro (BANEGAS et al., 2006).

A angiotensina II é o principal efetor do SRA (UNGER, 2003) e muitos efeitos da angiotensina II são mediados por sua interação com receptores de membranas específicos. Esses receptores são classificados farmacologicamente em dois tipos, os receptores $A T_{1}$ e $A T_{2}$ (EMANUELI et al., 2002), com base nas ligações de diferentes antagonistas (OLIVERIO e COFFMAN, 2000). Além isso, o receptor AT1 é subdividido em AT1a e AT1b em espécies murinas (EGAMI et al., 2003).

Ultimamente, pesquisadores têm se preocupado em demonstrar a relevância clínica e as possíveis aplicações terapêuticas destes novos achados envolvendo o SRA na medula óssea e seu papel no controle da hematopoese em seus diferentes estágios (STRAWN et al., 2004; HUBERT et al., 2006).

No entanto, as primeiras evidências das ações do SRA na medula óssea, foram citadas em 1980, quando Van Brummelen e colaboradores identificaram uma relação entre uma droga inibidora da ECA, o captopril e a presença de agranulocitose nos pacientes sob tratamento. Outros relatos envolvendo a droga inibidora da ECA e alterações na resposta hematopoética, como a granulocitopenia (CASATO, 1995; GUEST, 2001), neutropenia (COOPER, 1983; GUEST, 2001) e anemia aplásica (ISRAELI, 1985; GUEST, 2001) também foram relatadas uma década depois, com terapia em longo prazo com o captopril (SALAMA, 1992).

Em 1996, Haznedaroglu lançou a hipótese de que a presença do SRA na medula óssea afetava o crescimento, produção, proliferação e diferenciação de células hematopoéticas, principalmente através da participação da ECA, e em 1997, 
Mrug et al. (1997) demonstraram que a angiotensina II é capaz de induzir a proliferação eritróide através do cultivo de progenitores hematopoéticos CD34+, evidenciando assim, a importante participação da ECA no processo de regulação hematopoética.

A ECA é capaz de atuar como uma peptidil-dipeptidase sobre uma variedade de peptídeos biologicamente ativos. Dentre estes vários substratos podemos citar a neurotensina (SKIDGEL e ERDÖS, 2004), a $\beta$-endorfina (HAYAKARI et al., 1997), dinorfinas, Met ${ }^{5}$-encefalina (SKIDGEL e ERDÖS, 1987), etc. Porém nenhuma destas hidrólises foi observada in vivo. A ECA é capaz de hidrolisar ainda peptídeos com a extremidade C-terminal amidada, como a colecistocinina-8 e vários análogos da gastrina (DUBREUIL et al., 1989). Skidgel et al. (1994), mostraram a liberação do dipeptídeo e tripeptídeo amidados da Substância P pela ECA.

Finalmente, Rieger et al. (1993), verificaram que a ECA estava envolvida na hidrólise do AcSDKP e Rousseau et al. (1995), demonstraram a clivagem in vitro deste substrato pela ECA e constataram que o domínio $\mathrm{N}$ era 50 vezes mais eficiente do que o domínio $C$ na hidrólise deste peptídeo.

O papel da ECA na regulação da resposta hematopoética e a identificação de um dos seus principais substratos no microambiente medular, o AcSDKP tem sido amplamente investigado (COMTE et al. 1998; ROUSSEAU-PLASSE et al., 1998; GAUDRON et al., 1999; JUNOT et al., 1999; AZIZI et al., 2000; CHISI et al., 2000; RODGERS et al., 2000; AZIZI et al., 2001; JUNOT et al., 2001; JUNOT et al., 2001; KANASAKI et al., 2003; LIU et al., 2003; HAZNEDAROGLU e OZTURK, 2003; CHARRIER, et al., 2004). Chisi et al. (1999), demonstraram que a inibição da ECA no tecido hematopoético resulta num acúmulo do tetrapeptídeo AcSDKP. Como este peptídeo apresenta uma regulação negativa sobre a hematopoese, impedindo que as células pluripotentes da medula óssea entrem para a fase $S$ do ciclo celular (CASHMAN et al., 1994; AZIZI et al., 1996; MICHAUD et al., 1997; GAUDRON et al., 1999; IWAMOTO et al., 2000; AZIZI et al., 2001; JUNOT, 2001; HAZNEDAROGLU, 2003), sua possível aplicação como hematoprotetor tem sido investigada na presença de agentes quimioterápicos mielotóxicos (BOGDEN et al., 1991; JUNOT et al., 2001). Estes autores relataram que, durante a quimioterapia, o aumento do AcSDKP favorece o estado quiescente das células tronco hematopoéticas protegendo-as dos efeitos tóxicos da quimioterapia. Estudos clínicos em fase I 
demonstraram um aumento da sobrevida de indivíduo tratados com quimioterapícos em associação ao AcSDKP em relação aqueles tratados apenas com quimioterápicos convencionais (MASSÉ et al. 1998), deixando claro que este tetrapeptídio participa da resposta hematopoética. Porém o AcSDKP não inibe a proliferação de células tumorais na concentração utilizada na inibição de células tronco hematopoéticas (BONNET et al., 1992). O AcSDKP pertence à família de reguladores negativos da hematopoese (LIU et al., 2003) e foi pela primeira vez identificado em extratos de medula óssea de bezerros (LENFANT et al., 1989). A produção dessa molécula por células da medula óssea de camundongos foi verificada utilizando a cultura liquida de longa duração de células precursoras hematopoéticas (WDZIECZAK-BAKALA et al., 1990). Em humanos, este peptídeo pode ser localizado em diferentes tecidos, como baço, intestino, timo e medula óssea (ROUSSEAU et al., 1995). Com relação ao microambiente hematopoético, dados na literatura sugerem que macrófagos seriam os responsáveis pela produção do AcSDKP e, que logo em seguida, seriam degradados pela ECA na membrana das células estromais (LI et al., 1997). Outros autores, no entanto, propuseram que o AcSDKP seria produzido a partir do polipeptídeo $\beta 4$-timosina, uma vez que o AcSDKP representa a seqüência N-terminal desta timosina (GRILLON et al., 1990). Mais recentemente, Cavasin et al. (2004), mostraram que a prolil-oligopeptidase é a principal responsável pela liberação do AcSDKp, a partir da $\beta 4$-timosina.

Atualmente, as funções bioquímicas e mecanísticas deste tetrapeptídio e outros componentes reguladores da hematopoese, presentes no microambiente medular, têm sido intensamente estudadas (JACKSON et al., 2000; AZIZI et al., 2001; HAZNEDAROGLU, 2003; KANASAKI, 2003; LIU, 2003).

A ECA, além de agir sobre substratos clássicos, como a angiotensina I, e outros mais recentemente estudados, como o AcSDKP, também participa de maneira importante da inativação da bradicinina (BK) e da des-Arg ${ }^{9}$-bradicinina, produzidos pelo sistema calicreínas-cininas (SCC). (ERDÖS, 1990; IGNJATOVIC et al., 2002; VIO et al., 2003). 


\subsection{Sistema calicreína-cininas (SCC)}

As ações do SCC estão bem caracterizadas nos processos de transmissão de dor (DRAY e PERKINS, 1993), no controle da pressão arterial (SCHOLKENS, 1996), e na geração e manutenção do estado inflamatório (BHOOLA et al., 1992).

O SCC é formado por cininogênios, pelos precursores da BK e análogos, pelas calicreínas, as enzimas responsáveis pela geração de cininas, as próprias cininas, enzimas de degradação (cininases) e receptores de membrana plasmática, ligados a mecanismos variados de transdução.

As cininas são formadas pela hidrólise de cininogênio. As calicreínas são as enzimas responsáveis por esta hidrólise e pertencem ao grupo das serinoproteases. Uma vez formada, as cininas são rapidamente degradadas por peptidases genericamente chamadas de cininases (ERDÖS, 1990) e podem ser divididas em cininases I e II. A ECA, juntamente com a endopeptidase neutra, pertencem ao grupo das cininases II e assim, inativa a BK, um potente vasodilatador que atua ao estimular a liberação de óxido nítrico e de prostaciclinas.

As calicreínas são divididas em dois grupos principais: a tecidual e a plasmático, diferindo em massa molecular, ponto isoelétrico, especificidade de substrato e também no tipo de cinina liberada (BHOOLA et al., 1992).

A cinina liberada pela calicreína plasmática humana (assim como a do rato ou do camundongo) é a BK. Já as calicreínas do tecido humano liberam ou Lisbradicinina (calidina ou LBK), enquanto as dos roedores liberam BK. A BK, como a calidina, pode ser degradada por cininases do tipo I, como por exemplo, a carboxipeptidase $\mathrm{M}$, liberando des-Arg ${ }^{9}$-BK (DBK) e a des-Arg ${ }^{10}$-calidina (LEEBLUNDBERG et al., 2005; MOREAU, et al., 2005) (Figura 2). 


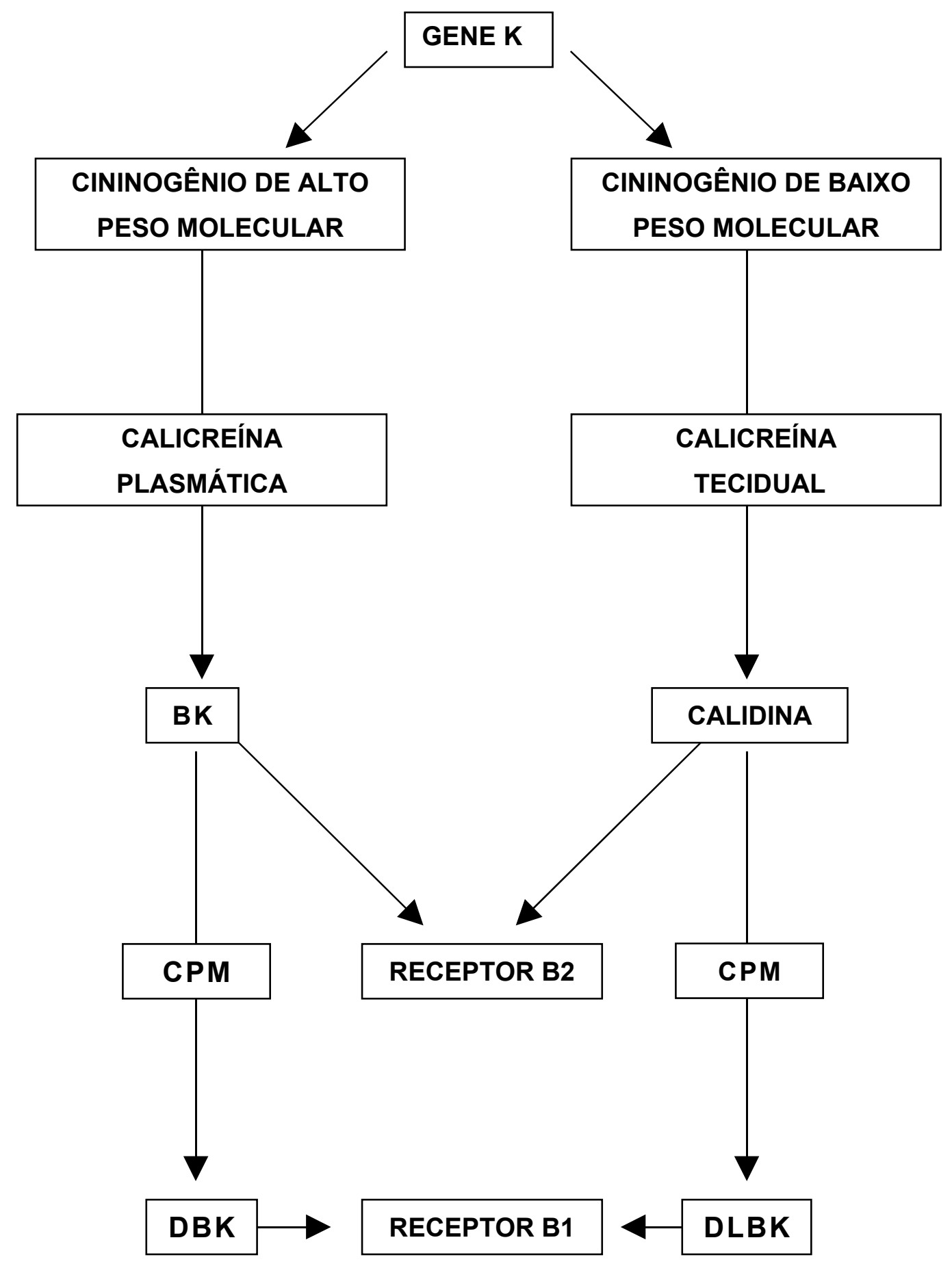

Figura 2 - Representação esquemática da ativação do sistema calicreína-cininas.

Cininogênio, sob ação da calicreína da origem à bradicinina (BK) e a Lysbradicinina (LBK), agonistas do receptor B2. Sob ação das carboxipeptidases a BK é hidrolisada em des-Arg ${ }^{9}$ bradicinina (DBK), e a LBK em des-Arg ${ }^{9}$ Lysbradicinina (DLBK), agonistas do receptor B1. 


\subsubsection{Receptores de cininas}

Estudos farmacológicos demonstraram que cininas desempenham seu grande espectro de ação pela ativação de dois subtipos de receptores denominados B1 e B2 (REGOLI e BARABÉ, 1980). A localização cromossômica dos genes destes receptores já foi encontrada em humanos no cromossomo 17q32 (MA et al., 1994 e CHAl et al., 1996) e em ratos, no cromossomo 6q3.2 (GÖSELE et al., 2000). Esses receptores pertencem à grande família dos receptores acoplados à proteína $G$ (GPCRs), e possuem sete hélices transmembranais, que 20-30 resíduos hidrofóbicos, ligados por três alças extracelulares e três citoplasmáticas, possuem uma região N-terminal extracelular e um domínio C-terminal citoplasmático. A homologia entre os dois receptores de cininas é de cerca de $35 \%$, sendo que a maior parte do segmento conservado se encontra na região transmembrana (MENKE et al., 1994).

\subsubsection{Receptor B2}

Acredita-se que a maior parte das ações da BK e LBK seja mediada pelo receptor B2. Este receptor possui baixa afiidade pela DBK. A seqüência desse gene foi determinada verificando-se que o mesmo codifica para uma proteína de 366 aminoácidos, com massa molecular de $41 \mathrm{kDa}$, pertencendo a família dos receptores com 7 domínios transmembrânicos acoplado à proteína G (MACEACHERN et al., 1991). Em 1994, Dan-Zhao et al., elucidaram a estrutura genômica do receptor B2 de ratos, observando que esse gene continha três exons separados por dois íntrons. Divergindo desses resultados, Pesquero et al. (1994) mostraram a presença de quatro exons e três íntrons no gene que codifica para o receptor B2 de cininas em ratos, além de demonstrarem a existência de splicing alternativo no exon 3 do gene.

Os receptores B2 têm sido descritos em numerosas preparações in vitro, incluindo aquelas do trato intestinal, cardiovascular, geniturinário e respiratório e em tecidos ocular e neuronal (HALL, 1992). Obedecendo esta larga distribuição, a maioria dos efeitos in vivo das cininas tem sido atribuído à ativação do receptor B2, 
incluindo broncoconstrição, hipotensão, reações inflamatórias agudas, dor e hiperalgesia (BURCH et al.; 1990; HALL, 1992).

\subsubsection{Receptor B1}

O receptor $\mathrm{B} 1$ tem sido descrito em várias espécies, principalmente em músculos lisos de coelho, rato, camundongo, cão, porco e também de humanos (HALL, 1992). Em 1995, Macneil et al., clonaram e caracterizaram o exon codificador do receptor B1 de coelho. Essa porção do gene codifica para uma proteína de 352 aminoácidos com similaridade de 78\% com o receptor B1 humano. O receptor B1 de camundongo foi clonado e caracterizado por Pesquero et al., em 1996. Os clones positivos revelaram que a área codificadora para esse receptor era ininterrupta, codificando para uma proteína de 334 aminoácidos e exibindo 7 domínios transmembrânicos.

Enquanto o receptor B2 é amplamente distribuído nos tecidos de mamíferos, o receptor B1 não apresenta atividade constitutiva (LEEB-LUNDBERG et al., 2001; FATHY et al., 1999) e após estimulação gera um aumento transiente na concentração de cálcio intracelular $\left(\left[\mathrm{Ca}^{+2}\right] \mathrm{i}\right)$, seguido de uma rápida desensibilizacao e internalização (MATHIS et al., 1996; FAUSSNER et al., 1999), o subtipo B1 é induzível (MARCEAU et al., 1995), constitutivamente ativo (LEEB-LUNDBERG et al., 2001), após estimulação mantém o aumento na $\left[\mathrm{Ca}^{+2}\right] \mathrm{i}$, não esta sujeito à desensibilização (MATHIS et al., 1996; FAUSSNER et al., 1999), e é translocado e sofre agregação (KANG et al., 2005)

Pesquero et al. em 2000, desenvolveram camundongos nocautes do receptor B1 de cininas. A caracterização fisiológica destes animais mostrou que os animais sem estes receptores apresentavam massa corporal maior que os animais selvagens aos 28 dias de nascimento, e essa diferença era mantida até os 90 dias de nascimento. Também observaram que o baço desses animais apresentava maior massa relativa quando comparados com os animais selvagens da mesma espécie. Foi verificada ainda uma menor ingestão de alimento relativo à massa corporal e aumento na atividade da NO sintase no hipotálamo, quando comparados aos animais selvagens da mesma espécie (ARAÚJO et al., 2001).

Finalmente, os receptores B1 das diferentes espécies descritas têm alta similaridade entre si, como também tem a sua expressão aumentada em processos 
inflamatórios (BHOOLA et al., 1992). Porém, a função fisiológica e o papel dos receptores $\mathrm{B} 1$ e $\mathrm{B} 2$ em quadros patológicos e no controle de processos fisiológicos na medula óssea são ainda pouco estudados.

\subsubsection{Medula óssea e sistema calicreína-cininas (SCC)}

Conforme pode ser verificado na figura 3, os SRA e SCC, se integram através de um elemento em comum, a ECA ou cininase II. Está bem caracterizado na literatura, que esta enzima, além de modular os níveis de angiotensina II, também regula os níveis endógenos de bradicinina (BK) (ERDÖS, 1990; IGNJATOVIC et al., 2002). A hipótese da participação do SCC na regulação da hematopoese passa por trabalhos realizados no final da década de 80 e início da década de 90 por Duma et al. e Moore et al., respectivamente. Os primeiros autores verificaram que a BK inibe a proliferação clonal de precursores mononucleares derivados da medula óssea murina. É interessante ainda mencionarmos que estes autores demonstraram que os efeitos inibitórios da BK são restritos aos fagócitos que dependem de dois sinais para serem estimulados a proliferar, sendo eles advindo do fator estimulador de células primitivas da medula óssea (stem cell factor - SCF-1) e de lipopolissacarídeos. Além disso, neste mesmo trabalho, foi relatado que os efeitos inibitórios da BK sobre estes fagócitos mononucleares dependiam da presença de células aderentes oriundas da medula óssea, as quais produzem prostaglandinas. Dois anos após o relato deste achados, o trabalho publicado por Moore et al. (1990), sugere que a $\mathrm{BK}$ e as prostaglandinas produzidas pelas células do microambiente medular agiam em sinergia no controle da produção de macrófagos, através da inibição da reposta de progenitores mielóides em transição, responsivos ao SCF-1.

Mais adiante, Naidoo et al., 1999 demonstraram por hibridização in situ a presença do mRNA para calicreína tecidual em neutrófilos e células precursoras hematopoéticas humanas. Araújo et al., 2001 também relataram que camundongos deficientes para o receptor B1 de cininas, apresentam redução na mobilização de neutrófilos após indução de peritonite e redução no processo apoptótico. 


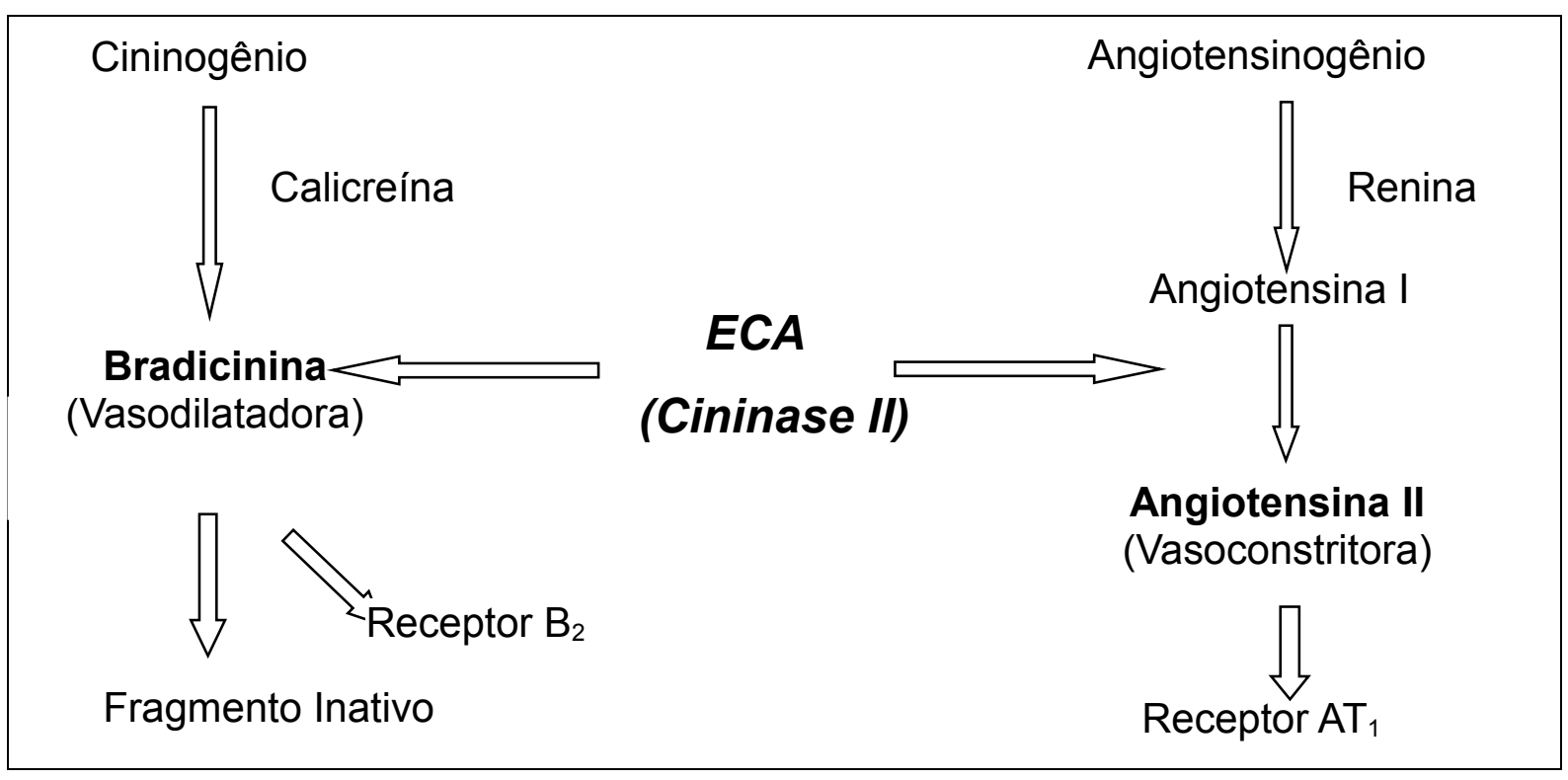

Figura 3 - Representação esquemática da relação entre atividade da ECA (cininase II) e os SRA e SCC. Sendo a bradicinina também inativada pela ECA, a inibição da atividade desta enzima resulta em alterações na cascata envolvendo o SCC.

Assim sendo, diante da complexidade da resposta hematopoética, das evidências da existência do SRA no microambiente medular e também diante das suposições sobre a participação de elementos do SCC neste processo de formação das células sanguíneas, torna-se importante a caracterização tanto da presença, como da atividade de elementos destes dois sistemas. Neste sentido, a ECA, ao desempenhar importantes funções em ambos os sistemas, poderia ter grande importância em uma possível participação no mecanismo regulatório da hematopoese, portanto, a caracterização da sua presença e avaliação da sua atividade catalítica no microambiente hematopoético, poderá fornecer dados sobre o possível envolvimento destes sistemas sobre o processo de formação de células sanguíneas, além da possível interação destes dois sistemas fisiológicos neste controle. 


\subsection{Interação entre os sistemas calicerína-cininas e renia-angiotensina}

Os sistemas calicreínas-cininas e renina-angiotensina são importantes na etiologia da hipertensão e patogênese de danos cardíaco e renal associados com elevada pressão sanguínea. Enquanto a angiotensina II atua aumentando a pressão sanguínea, as cininas tem efeito oposto, protetor. Os dois sistemas interagem em vários níveis.

Recentes observações indicam que a estimulação de receptores AT1 pode modular a expressão de receptores de cininas. Ensaios realizados in vitro demonstraram que o tratamento de culturas de células de músculo liso vascular de ratos com angiotensina II induziu a expressão de receptores B1 (KINTSURASHVILI et al., 2001) e B2 (TAN et al., 2004), e em ambos os casos, a indução foi bloqueada pelo antagonista de receptor AT1, losartan. Em 2002, Abdalla et al., descreveram a formação de heterodímeros estáveis entre receptores AT1 de angiotensina II e B2 de BK em culturas de células de músculo liso vascular. Interessantemente, a presença de heterodímeros formados por receptores AT1/B2 foi também descrita em plaquetas e em vasos sanguíneos de mulheres com pré-eclampsia, síndrome classicamente caracterizada pelo aumento de sensibilidade aos efeitos pressores de Agiontesina II (QUITTERER et al., 2004).

Certamente o aspecto mais estudado da interação dos dois sistemas é a potencialização de BK por inibidores da ECA. Fármacos inibidores da ECA são amplamente utilizados no tratamento da hipertensão arterial e eventos cardiocirculatórios, e sabe-se que seus efeitos benéficos não se devem exclusivamente à redução dos níveis de angiotensina II, mas também a menor taxa de metabolização de BK (LINZ et al., 1995; LINZ et al., 1999). Inibidores da ECA potencializam os efeitos mediados por cininas na presença de concentrações submáximas de peptídeos, restabelecem a resposta de cininas após a dessensibilização de receptores B2 e ainda potencializam os efeitos mediados por receptores B2 mesmo quando as cininas usadas nos ensaios são resistentes à ECA (AUCHSCHWELK et al., 1992; HECKER et al., 1994; MINSHALL et al., 1997b). Com bases 
nessas evidências, sugere-se que os inibidores da ECA possam ativar diretamente receptores B2 ou ainda facilitar a interação enzima receptor, potencializando a sinalização celular estimulada por BK (HECKER et al., 1994; HECKER et al., 1997; MINSHALL et al., 1997a; LINZ et al., 1999).

Ensaios realizados em células obtidas de ovário de hamister chinês, cotransfectadas com gene que expressa a ECA e o receptor B2 de cininas, constataram a formação do complexo ECA/B2 nestas células, e seus resultados demonstraram um modo de ação que poderia contribuir para o sucesso terapêuticos dos inibidores da ECA (CHEN et al., 2006).

Marcic et al. (1999), demonstraram que o enaprilato foi capaz de ressensibilizar o receptor B2 em cultura de células endoteliais de artéria pulmonar bovina, que expressam a ECA e o receptor B2. O mesmo efeito, deste inibidor da ECA, já havia sido observado em átrio esquerdo de cobaia. (MINSHALL et al., 1997a). Posteriormente, Marcic et al. (2000), demonstraram que as proteínas, ECA e o receptor $\mathrm{B} 2$, se encontram estéricamente associadas na membrana, provavelmente formando um heterodímero, e que os inibidores da ECA alterariam a interação deste complexo, levando a uma conformação favorável do receptor B2 para induzir uma transdução de sinal mais eficiente.

Por isso, diante da complexa interação molecular entre elementos do SCC e do SRA e diante da falta de dados na literatura que indiquem a possibilidade desses elementos participarem de alguma forma da resposta hematopoética, trabalhos nesta área podem trazer resultados interessantes sobre elementos destes sistemas bem estabelecidos em outros órgãos, porém pouco investigados no microambiente medular. 


\section{OBJETIVOS}

\subsection{Gerais}

Diante das evidências de que a ECA regula as concentrações endógenas de AcSDKP e também diante do fato de que esta enzima é um elemento em comum dos SRA e do SCC, neste trabalho, investigamos o padrão de expressão da ECA, assim como avaliamos a influência da atividade desta enzima sobre o processo proliferativo medular em animais WT e KOB1, além de avaliarmos as populações medulares envolvidas na expressão da ECA no tecido medular.

\subsection{Específicos}

Utilizando camundongos WT e KOB1, realizar os seguintes estudos in vitro e in vivo:

\subsubsection{Estudos in vitro}

A partir do estabelecimento de culturas líquidas de longa duração a partir de células da medula óssea de animais WT e KOB1, realizar os seguintes estudos:

- Avaliar o crescimento e diferenciação de precursores hematopoéticos para granulócitos e macrófagos (CFU-GM) através de ensaios clonogênicos em soft-ágar a partir da cultura líquidas de longa duração;

- Avaliar a expressão gênica e protéica da ECA em células (aderentes e não aderentes) obtidas das culturas líquidas de longa duração, através de western blotting e PCR em tempo real.

- Avaliar a atividade catalítica da ECA, através de ensaio fluorimétrico com substrato específico, a partir das culturas líquidas de longa duração; 
- Realizar a imunofenotipagem das populações hematopoéticas obtidas das culturas líquidas de longa duração;

- Realizar ensaio de microscopia confocal de fluorescência para identificar a ECA em células das culturas líquidas de longa duração.

- Quantificar os níveis de AcSDKP no sobrenadante das culturas líquidas de longa duração através de ensaio imunoenzimático e avaliar os efeitos do AcSDKP sobre a proliferação de células hematopoéticas obtidas no sobrenadante das culturas líquidas de longa duração através da análise por citometria de fluxo.

\subsubsection{Estudos in vivo}

- Determinar a atividade da ECA através de ensaios fluorimétricos a partir da medula óssea obtida dos animais.

- Quantificar os progenitores hematopoéticos para granulócitos e macrófagos (CFU-GM) de animais tratados com AcSDKP e captopril.

- Avaliar a expressão gênica da ECA e dos receptores B1 e B2 de cininas, através da técnica Real Time RT-PCR.

- Realizar imunofenotipagem das células da medula óssea dos animais estudados associada à marcação com anticorpos anti-ECA para murinos e analisar através de citometria de fluxo quais populações expressam a enzima. 


\section{MATERIAL E MÉTODOS}

\subsection{Compostos químicos}

3.1.1 Captopril (D-3-mercapto-2-metilpropionil-L-prolina) e AcSDKP ( $\mathrm{N}$-acetylSer-Asp-Lys-Pro)

O composto químico inibidor da ECA (Captopril) e o peptídeo AcSDKP, regulador negativo da hematopoese foram adquiridos da Sigma Chemical Co.

\subsubsection{Substrato fluorogênico da ECA (Abz-YRK(Dnp)P-OH)}

O peptídeo fluorogênico Abz-YRK(Dnp)P-OH foi gentilmente cedido pela Prof. $\mathrm{Dr}^{\mathrm{a}}$ Adriana K. Carmona do Departamento de Biofísica da Universidade Federal de São Paulo (UNIFESP).

\subsubsection{Des-Arg ${ }^{9}$ bradicinina e Lys-bradicinina}

Os compostos Des-Arg ${ }^{9}$ bradicinina (DBK) e Lys-bradicinina (LBK) foram gentilmente cedidos pelo Prof. Dr. João Bosco Pesquero do Departamento de Biofísica da Universidade Federal de São Paulo (UNIFESP).

\subsection{Animais}

\subsubsection{Animais nocautes KOB1}

O presente estudo utilizou camundongos machos, com idade entre 6-8 meses mantidos a $22 \pm 2^{\circ} \mathrm{C}$, sob um ciclo claro/escuro de 12 horas. Os animais foram fornecidos pelo Centro de Desenvolvimento de Modelos Experimentais em Medicina e Biologia (CEDEME) da Universidade Federal de São Paulo (UNIFESP). Foram utilizados camundongos nocautes para os receptores B1 (KOB1). Grupos controle 
(WT) foram definidos de acordo com a linhagem original do nocaute: animais C57BL/6 puros foram utilizados como controle para os animais KOB1.

A seleção, alojamento, manipulação e número de sujeitos experimentais foram considerados adequados de acordo com o parecer do Comitê de Ética em Manipulação e Experimentação Animal (CEMEA) da Universidade de Mogi das Cruzes (UMC), local de realização dos procedimentos com os animais e estabelecimentos das culturas celulares.

\subsubsection{Tratamento dos animais WT e KOB1}

Os animais utilizados no experimento in vivo foram divididos em grupos de 5 animais $(n=5)$ e submetidos aos seguintes tratamentos: a) animais que receberam solução salina por via subcutânea $2 x$ ao dia; b) animais que receberam $10 \mu \mathrm{g}$ de AcSDKP (diluído em salina) por via subcutânea $2 x$ ao dia e c) animais que receberam $100 \mathrm{mg} / \mathrm{kg}$ de captopril (diluído em salina) por via subcutânea 2x ao dia. Todos os grupos foram tratados por 4 dias consecutivos.

\subsection{Técnicas de cultivo celular}

\subsubsection{Cultura de líquida de longa duração (CLLD)}

Neste ensaio avaliamos a proliferação mielóide como previamente descrito por Dexter et al. (1977). Após a eutanásia dos animais através de deslocamento cervical, a pele foi limpa com álcool iodado. Com auxilio de pinças e tesouras, os fêmures dos camundongos WT e KOB1 foram retirados, todo o tecido conjuntivo não-ósseo removido e a cavidade medular aberta e, com auxílio de seringa, agulha e meio de cultura, retiramos a medula óssea ("flushing"). As células foram homogeneizadas com auxílio de pipeta Pasteur, em meio a-MEM (Sigma) suplementado com L-glutamina, $20 \%$ de soro eqüino (Gibco), succinato de hidrocortisona $\left(10^{-6} \mathrm{M}\right)$ e antibióticos. Após este procedimento, as suspensões celulares foram transferidas para garrafas de $25 \mathrm{~cm}^{2}$ (TTP) $\left(1 \times 10^{7}\right.$ células/garrafa) em um volume final de $10 \mathrm{~mL}$. As culturas foram mantidas em estufa úmida com $5 \%$ de $\mathrm{CO}_{2}$, a $37{ }^{\circ} \mathrm{C}$ e semanalmente, $50 \%$ do meio foi renovado. 


\subsubsection{Ensaio clonogênico em soft-ágar de progenitores hematopoiéticos para granulócitos e macrófagos (CFU-GM) a partir de células sobrenadantes das CLLD}

A partir da $5^{\text {a }}$ semana de cultivo, após completa confluência da monocamada, foram realizadas coculturas de células hematopoéticas. Para isso, foram obtidas novas células através da realização do "flushing" em fêmures de animais WT e KOB1, conforme descrito no item 3.1. Em seguida, as células foram homogeneizadas com auxílio de pipeta Pasteur em meio a-MEM suplementado com $10 \%$ de soro fetal bovino e antibióticos. A suspensão celular foi transferida para placas de Petri de $60 \mathrm{~mm}$ e incubada em estufa úmida $\mathrm{CO}_{2}$, a $37^{\circ} \mathrm{C}$, por 1 hora, para retirada de células aderentes. Após a adesão, as células não-aderentes foram homogeneizadas e transferidas para um tudo de $15 \mathrm{~mL}$. Em seguida, as células as foram separadas por densidade, utilizando Ficoll na densidade de $1,077 \mathrm{~g} / \mathrm{cm}^{3}$, centrifugando por 45 minutos, à $2000 \mathrm{~g}$. As células presentes na interface do meio de cultura com Ficoll foram recolhidas, lavadas 3 vezes em salina e contadas. Em seguida foram preparadas suspensões de $1 \times 10^{6}$ células $/ \mathrm{mL}$. Finalmente, as células foram transferidas para os frascos de cultura juntamente com os compostos AcSDKP (1 $\eta \mathrm{M})$ e captopril $(1 \mu \mathrm{M})$.

A cada semana $50 \%$ do meio foram removidos e adicionados iguais volumes de meio fresco juntamente com os compostos de tratamento. $O$ volume retirado (5 $\mathrm{mL}$ ) de meio de cultura foi coletado, centrifugado (10 min. a $1.500 \mathrm{rpm}$ ) e o "pellet" ressuspendido em $1 \mathrm{~mL}$ de meio $\alpha$-MEM para a realização da contagem de células não-aderentes (viáveis) com azul de trypan (diluição 1:10) em câmara hemocitométrica. Para o ensaio clonogênico, foi preparado meio semi-sólido (Bactoágar, Difco), que foi composto por 30\% de meio DMEM (Dulbecco's Modified Eagle's Médium - Difco) 2 x concentrado, $20 \%$ de soro fetal bovino e $50 \%$ de ágar (concentração final de 0,3\%). A seguir, foi adicionado volume apropriado de células $\left(1 \times 10^{5}\right.$ células $\left./ \mathrm{mL}\right)$ em meio adicionado de ágar $\left(37^{\circ} \mathrm{C}\right)$. As suspensões celulares foram distribuídas em volumes de 2,0 mL para cada placa de Petri (35 mm), que já continham $100 \mu \mathrm{L}$ do fator GM-CSF recombinante. O conteúdo foi distribuído por toda a superfície da placa. As placas foram incubadas por 7 dias a $37^{\circ} \mathrm{C}$ em 
presença de $5 \%$ de $\mathrm{CO}_{2}$, a seguir foi contado o número de colônias em microscópio de dissecção com aumento de 400x (Figura 4). Ao final do cultivo, as monocamadas foram dissociadas com tripsina para a contagem das células aderentes.

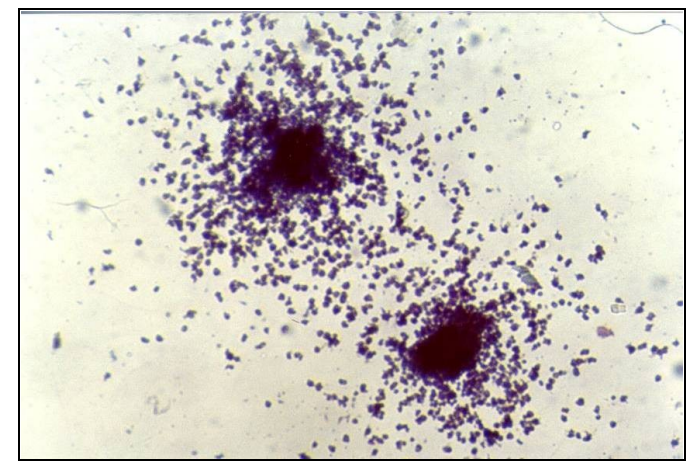

Figura 4 - Aspecto microscópico de colônias de granulócitos e macrófagos (CFU-GM) obtidas da medula óssea de camundongos (aumento $400 \mathrm{x}$ ).

\subsubsection{Ensaio clonogênico em soft-ágar de progenitores hematopoiéticos para granulócitos e macrófagos (CFU-GM) a partir de células da medula óssea de animais WT e KOB1 tratados com AcSDKP e captopril}

Após a eutanásia dos animais através de deslocamento cervical., a pele foi limpa com álcool iodado. Com auxilio de pinças e tesouras, os fêmures dos camundongos WT e KOB1 foram retirados, todo o tecido conjuntivo não-ósseo removido e a cavidade medular aberta e, com auxílio de seringa, agulha e meio de cultura, retiramos a medula óssea ("flushing"). O volume coletado da suspensão celular foi centrifugado (10 min. a 1.500 rpm) e o "pellet" ressuspendido em $1 \mathrm{~mL}$ de meio $\alpha$-MEM para a realização da contagem de células viáveis com azul de trypan (diluição 1:10) em câmara hemocitométrica. Após obtenção da suspensão celular e do volume apropriado, o ensaio clonogênico foi realizado de acordo com o item 3.1.1.1 


\subsubsection{Cocultura de células hematopoéticas mononucleares para imunofenotipagem e análise do ciclo celular}

Em placas de 6 poços (TPP) foram estabelecidas monocamadas de acordo com o descrito por Dexte et al. (1977) e conforme o item 3.1, tendo como única diferença, a densidade celular plaqueada, que neste caso foi de $1 \times 10^{6}$ celulas/poço. Foram cultivadas células totais de medula óssea de camundongos WT e KOB1 até atingirem $70 \%-100 \%$ de confluência. Neste estágio, o meio foi retirado e $2 \mathrm{~mL}$ da suspensão de células hematopoéticas foram adicionadas a cada poço. $O$ procedimento para obtenção das células hematopoéticas mononucleares foi descrito anteriormente no item 3.1.1.1. Contudo, após coletar as células presentes na interface do meio de cultura com Ficoll, e proceder as lavagens (3 vezes em salina), estas foram contadas e em seguida preparadas suspensões de $2 \times 10^{5}$ células $/ \mathrm{mL}$.

A cada semana, $50 \%$ de meio era retirado e o mesmo volume de meio fresco era adicionado. No caso de um dos grupos de coculturas de animais KOB1, era juntamente adicionado captopril $(1 \mu \mathrm{M})$. Após 2 semanas as culturas foram avaliadas. Para isso, foi realizada dissociação mecânica das células, seguida de homogeneização e passagem em membrana de "nylon", para retirada de grumos de células estromais. As células foram contadas para posterior imunofenotipagem e avaliação do ciclo celular.

\subsubsection{Imunofenotipagem de células hematopoéticas obtidas das coculturas e tratadas com captopril}

Para a imunofenotipagem, as células hematopoéticas obtidas de animais WT e KOB1 foram cocultivadas e tratadas com captopril $(1 \mu \mathrm{M})$ durante 2 semanas, conforme descrito no item 3.3. Após este período, as células foram coletadas e homogeneizadas com auxílio de pipeta Pasteur, em meio $\alpha$-MEM suplementado com $10 \%$ de soro fetal bovino. Após isso, as células foram centrifugadas por $10 \mathrm{~min}$. a 1200 rpm e contadas em câmara hemocitométrica. Um total de $1 \times 10^{6}$ células por amostra foram fixadas em solução de paraformaldeído 2\% "FACs Lysing" e marcadas com os anticorpos conjugados anti-Gr-1-FITC, anti-Mac-1-PE, anti-c-KitAPC por 20 minutos. As amostras também foram marcadas com o anticorpo primário 
Ter-119 por 2 horas. Para visualizar a marcação primária utilizamos o anti-lgG de coelho produzido em cabra conjugado com Alexa Fluor 488 por 40 minutos. As leituras foram realizadas no citômetro de fluxo FACsCalibur (Becton Dickinson, CA, USA) e as análises através do programa WinMDI.

\subsubsection{Avaliação do ciclo celular de células hematopoéticas obtidas das coculturas tratadas com AcSDKP e captopril}

Para a realização das análises do ciclo celular, células hematopoéticas obtidas de animais WT e KOB1 foram cocultivadas e tratadas com AcSDKP (1 ฤM) e captopril $(1 \mu \mathrm{M})$ durante 2 semanas, conforme descrito no item 3.3. Após isso, as células foram coletadas e homogeneizadas com auxílio de pipeta Pasteur. Em seguida foram fixadas em solução de paraformaldeído $2 \%$ "FACs Lysing" e tratadas por 30min com $4 \mathrm{mg} / \mathrm{mL}$ de RNase a $37 \mathrm{C}$ e marcadas com "syto-green" (1 $\mu \mathrm{M})$ cuja emissão é capturada no detector FL-1 ou iodeto de propídeo (PI - $5 \mu \mathrm{g} / \mathrm{ml}$ ). O "sytogreen", quando usado, permite a utilização de outros anticorpos conjugados com fluoróforos para os detectores FL-2, FL-3 e FL4 (anti-Gr-1/St-PERCP, anti-Mac-1-PE e anti-c-Kit). O histograma do conteúdo de DNA foi lido no canal FL1 para "sytogreen" ou FL2 para PI em escala logarítmica.

A análise do ciclo celular foi realizada quantificando a porcentagem das regiões sub- $\mathrm{G}_{0} / \mathrm{G}_{1}, \mathrm{G}_{1} / \mathrm{G}_{0}$ e $\mathrm{S} / \mathrm{G}_{2} / \mathrm{M}$ como mostrado na figura 5 utilizando o programa CELLQuest (versão 3.4, Becton Dickinson) e Windi 2.8. 


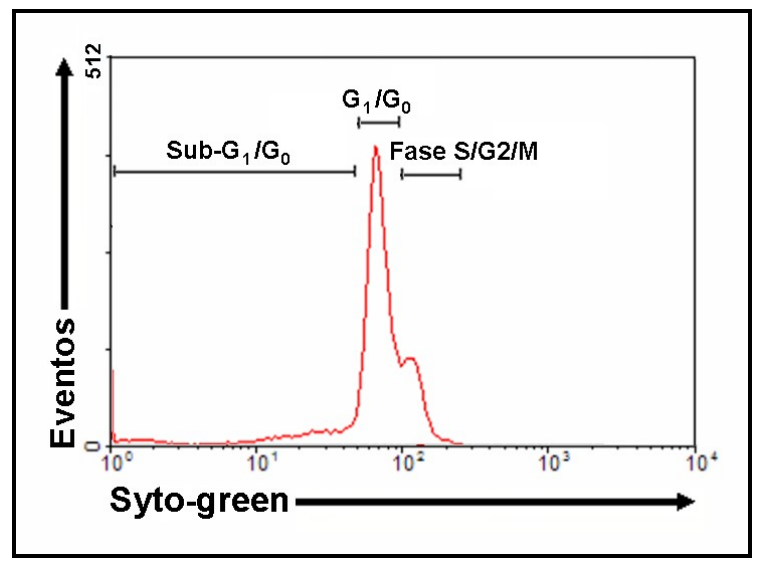

Figura 5 - Mensuração das fases do ciclo celular. Histograma do conteúdo de DNA por "syto-green" é lido no detector FL1 em células de CLLD. As células que apresentam baixo conteúdo de DNA (sub- $\mathrm{G}_{0} / \mathrm{G}_{1}$ ) são as células em apoptose. As células em $\mathrm{G}_{0} / \mathrm{G}_{1}$ são as células que não entraram no ciclo celular. As células na Fase S e M (mitose) são as células que estão dividindo-se.

\subsection{Determinação da atividade da ECA nas CLLD tratadas com AcSDKP, captopril, DBK e LBK}

A atividade enzimática foi realizada conforme descrito por Friedland \& Silverstein (1976). As CLLD foram estabelecidas conforme item 3.1 e dividas em grupos que receberam logo a partir da $1^{\text {a }}$ semana e, a partir daí, semanalmente, os diferentes tratamentos como segue: a) AcSDKP (1 ПM); b) captopril (1 $\mu \mathrm{M})$; c) DBK $(1 \mu \mathrm{M}) ;$ d) LBK $(1 \mu \mathrm{M}) ;$ e) salina (controle). Semanalmente, $50 \%$ do meio $(5 \mathrm{~mL})$ eram coletados para a contagem de células não-aderentes (viáveis) e $50 \%$ de meio fresco, mais os compostos de tratamento eram repostos ao sistema de cultivo.

Ao término da $4^{a}$ semana de tratamento, seguiu-se o ensaio fluorimétrico com as monocamadas sendo lavadas 3 vezes com salina e tratadas com uma solução de lise Tris $\mathrm{HCl} 50 \mathrm{mM} \mathrm{0,1 \%} \mathrm{Triton} \mathrm{X-100} \mathrm{(Sigma).} \mathrm{Após} \mathrm{esta} \mathrm{etapa,} \mathrm{as} \mathrm{células} \mathrm{foram}$ centrifugadas a $30.000 \mathrm{rpm}$ por 10 minutos. A atividade da ECA foi determinada através de ensaio fluorimétrico (excitação $320 \mathrm{~nm}$ e emissão $420 \mathrm{~nm}$ ) utilizando-se como substrato para a ECA, o peptídeo com supressão intramolecular de fluorescência Abz-YRK(Dnp)P-OH (ARAUJO et al., 2000; ALVES et al., 2005). Resumidamente, cerca de $200 \mu \mathrm{L}$ da suspensão de células (lisado) foram incubados, a $37{ }^{\circ} \mathrm{C}$ e em seguida, adicionados $1 \mu \mathrm{M}$ do substrato Abz-YRK(Dnp)P-OH no 
tampão TrisHCl $100 \mathrm{mM}, \mathrm{pH}=8,0$, contendo $300 \mathrm{mM} \mathrm{NaCl}$ e $50 \mu \mathrm{M} \mathrm{ZnSO}_{4} . \mathrm{A}$ hidrólise foi acompanhada diretamente no fluorímetro, por meio da medida da velocidade. Após 3 minutos de reação, adicionou-se $1 \mu \mathrm{M}$ do inibidor específico da ECA, captopril, e novamente mediu-se a velocidade de hidrólise. A atividade da ECA foi calculada dividindo-se o valor da velocidade pela concentração de proteína usada no ensaio.

\subsection{Avaliação da expressão gênica da ECA e de receptores B1 e B2 de cininas nas CLLD e na medula óssea de animais WT e KOB1, através de RT-PCR em tempo real}

A expressão estável de genes da ECA e de receptores B1 e B2 em células da medula óssea ou de CLLD, foi investigada. Em relação à expressão dos receptores B1 e B2, esta foi avaliada tanto em células das CLLD, como na medula óssea de animais WT, sem tratamento prévio.

A expressão da ECA foi avaliada na medula óssea de animais WT e KOB1, bem como em células das CLLD destes mesmos animais. Com relação às culturas, estas foram submetidas aos diferentes tratamentos, por 4 semanas e mostrados a seguir: a) DBK (1 $\mu \mathrm{M})$; b) LBK (1 $\mu \mathrm{M})$; c) captopril (1 $\mu \mathrm{M})$; d) AcSDKP (1, 3 e $5 \eta \mathrm{M})$ e finalmente, e) salina (controle).

Após a obtenção da monocamada, ao termino da $4^{a}$ semana, conforme descrito no item 3.1, e após a realização dos diferentes tipos de tratamento, seguiuse à extração do RNA total para avaliarmos a expressão gênica da ECA e dos receptores B1 e B2. No caso das medulas frescas, após a realização do "flushing", estas eram prontamente submetidas à extração do RNA.

Deste modo, o RNA total foi extraído tanto das células da medula óssea, como das células das CLLD de animais WT e KOB1, utilizando-se TRIzol® na proporção de $1 \mathrm{~mL}$ para cada $10 \mathrm{~cm}^{2}$ de células em monocamada. Em seguida foram adicionados ao homogenato $200 \mu \mathrm{L}$ de clorofórmio para cada $1 \mathrm{~mL}$ de TRIzo|®, seguindo-se agitação e centrifugação $\left(1.200 \times \mathrm{g}\right.$, por $15 \min$, a $\left.4{ }^{\circ} \mathrm{C}\right)$. A solução resultante apresentou três fases. A fase aquosa contendo o RNA foi submetida à reação de transcrição reversa $(\mathrm{RT})$. 
Para evitar a possibilidade das amostras estarem contaminadas por DNA genômico, todas foram previamente tratadas com DNAse I por 1 hora para posteriormente serem realizadas as reações de RT-PCR.

Para a reação de transcrição reversa foi seguido o seguinte protocolo:

$2 \mu \mathrm{g}$ de RNA total (livre de DNA)

$2 \mu \mathrm{L}$ de Tampão de PCR (10x)

$1,0 \mu \mathrm{L}$ de dNTPs $(10 \mathrm{mM})$

$1,0 \mu \mathrm{L}$ de $\mathrm{MgCl}_{2}(50 \mathrm{mM})$

$1,0 \mu \mathrm{L}$ de Hexâmeros Randômicos (50 $\mathrm{g} / \mu \mathrm{L})$

$1,0 \mu \mathrm{L}$ de RNAse OUT- RNAse Inhibitor $(40 \mathrm{U} / \mu \mathrm{L})$

$1,0 \mu \mathrm{L}$ de M-MLV Reverse Transcriptase

q.s.p $20 \mu \mathrm{L}$ de $\mathrm{H}_{2} \mathrm{O}$ DEPC

Programação do termociclador:

1. $20^{\circ} \mathrm{C}$ por $10 \mathrm{~min}$

2. $42^{\circ} \mathrm{C}$ por $45 \mathrm{~min}$

3. $95^{\circ} \mathrm{C}$ por $5 \mathrm{~min}$

4. $4{ }^{\circ} \mathrm{C}$ por $10 \mathrm{~min}$

A quantificação do mRNA foi avaliada por Reação de Polimerase em Cadeia em Tempo Real (q-PCR) indiretamente por meio de DNA complementar (cDNA) sintetizado a partir do RNA total extraído.

Do resultado da RT, aproximadamente 200 ng de cDNA foi utilizado como molde para o q-PCR, aos quais foram adicionados $10 \mu \mathrm{L}$ de Master Mix (Applied Biosystems) e $1 \mu \mathrm{L}$ de uma mistura contendo os dois oligonucleotídeos (18 $\mu \mathrm{M}$ cada) e uma sonda MGB marcada com FAM (5 $\mu \mathrm{M})$, todos específicos para o MRNA do receptor $\mathrm{B} 1, \mathrm{~B} 2$ e ECA e $1 \mu \mathrm{L}$ dos oligonucleotídeos específicos para MRNA de $\beta$ actina (5 $\mu \mathrm{M}$ cada) e $1 \mu \mathrm{L}$ de sonda MGB marcada com VIC para $\beta$-actina $(5 \mu \mathrm{M})$. A Lista dos conjuntos de sondas e primers utilizados na q-PCR encontra-se na tabela 7 (apêndice).

Durante a amplificação, a atividade exonuclease da polimerase cliva a sonda e libera o reporter do apagador, que também está fixado à sonda, gerando um aumento na intensidade da fluorescência emitida pelo reporter. Os níveis de fluorescência crescem exponencialmente e são detectados ciclo a ciclo em tempo real. O ciclo da PCR no qual o nível de fluorescência passa a ter um valor significativo é considerado o parâmetro inicial para a análise da expressão do MRNA 
e é denominado Ct (ciclo threshold). Quanto maior o número de cópias de um determinado MRNA, menor será o Ct. O valor normatizado ( $\mathrm{Ct}$ ) é obtido subtraindo o Ct obtido para cada gene avaliado do Ct obtido para a $\beta$-actina. Entretanto, não é comum utilizar o $\mathrm{Ct}$ como valor de expressão relativa, devido às suas características logarítmicas. O valor utilizado para indicar a expressão relativa foi obtido pela fórmula $2^{-\mathrm{Ct}}$.

As amostras foram submetidas à sequenciamento no aparelho $\mathrm{ABI} 7000$ Sequence Detection System (Applied Biosystems) ao seguinte protocolo: $50{ }^{\circ} \mathrm{C}$ por 5 min; $94{ }^{\circ} \mathrm{C}$ por $10 \mathrm{~min} ; 40$ ciclos a $94{ }^{\circ} \mathrm{C}$ por $15 \min$ e $60{ }^{\circ} \mathrm{C}$ por $1 \mathrm{~min}$.

\subsection{Dosagem de AcSDKP no sobrenadante e nas células presentes no sobrenadante das CLLD}

Os meios condicionados das CLLD foram coletados ao final da $4^{\mathrm{a}}$ semana, após abertura destas culturas conforme descrito no item 3.1. A amostras foram coletadas na presença de captopril $\left(10^{-5} \mathrm{M}\right.$ ) (Sigma), com o objetivo de bloquear a atividade da ECA que contribui para o catabolismo deste peptídeo in vivo. O meio condicionado foi imediatamente separado por centrifugação a 3000 g por 15 minutos at $4 \mathrm{C}$ e estocado a $20 \mathrm{C}$ até a determinação extracelular de AcSDKP. Para as células presentes no meio condicionado, e deste modo, para determinação intracelular de AcSDKP, as células foram submetidas a ação de um ultra som por 20 s. Os níveis de AcSDKP foram medidos através da técnica de ELISA competitivo como descrito previamente (PRADELLES et al., 1990). Cada well da microplaca apresentava imobilizado no seu interior, um "mouse monoclonal anti-rabbit immunoglobulins" (Alpco). Além disso, o AcSDKP conjugado com acetilcolinesterase, anti-AcSDKP e padrões ou amostras foram adicionados a cada well. Após 18 horas de incubação at $4 \mathrm{C}$, as placas foram lavadas com tampão fosfato contendo 0,05\% de Tween 20 e pH 7,4 e finalmente, $200 \mu \mathrm{L}$ de substrato enzimático (Ellman's) foram adicionados. Após 5h de incubação em câmara escura, a densidade ótica foi medida a $405 \mathrm{~nm}$ para cada well. Os resultados foram expressos em $\mathrm{pmol} / \mathrm{mL}$ de AcSDKP no meio condicionado e $\mathrm{pmol} / \mathrm{mg}$ de tecido nas células presentes no sobrenadante. 
A concentração de proteínas da medula óssea foi determinada como descrito pelo método de Bradford (BRADFORD, 1976).

\subsection{Microscopia Confocal}

As CLLD obtidas a partir de células da medula óssea animais WT foram realizadas em poços com lamínula de vidro de $13 \mathrm{~mm}$ nas condições descritas anteriormente. As células foram fixadas com paraformaldeído $2 \%$ em PBS por 30 min, posteriormente foram lavadas com $0,1 \%$ de glicina e permeabilizadas em saponina 0,01\% ambas diluídas em PBS. As células foram incubadas por 2 horas com os anticorpos anti-ECA (1:100) fabricado em camundongo. O anticorpo foi diluídos em PBS com 1\% de BSA. Para a visualização desta marcação foi utilizado o anticorpo secundário anti-lgG de camundongo conjugado com Alexa Fluor 488 (4 $\mathrm{g} / \mathrm{ml}$ ) durante $40 \mathrm{~min}$. O núcleo foi corado por DAPI (4,6 - diamidino - 2 - fenilindole, dihidroxicloride) durante $20 \mathrm{~min}(20 \mathrm{~g} / \mathrm{ml})$. O fluoróforo Alexa Fluor 488 foi excitado com o laser de argônio 488 nm sendo a emissão capturada com o filtro de emissão de 500 a $550 \mathrm{~nm}$ (Verde). O fluoróforo DAPI foi excitado como laser multifoton em $760 \mathrm{~nm}$, correspondente à excitação aproximada de $380 \mathrm{~nm}$ de um laser multifoton, utilizando-se o filtro de emissão de 400 a $465 \mathrm{~nm}$. As leituras das imagens foram realizadas no microscópio confocal LSM 510 META (Zeiss).

\subsection{Western blotting}

Para determinar a quantidade relativa à massa molecular da ECA dentro de uma mistura de proteínas resultantes do homogenato realizado com as CLLD obtidas a partir da medula óssea de animais WT e KOB1 realizamos a técnica de western blotting.

Primeiramente as CLLD foram estabelecidas conforme descrito no item 3.1. Após isso, ao término da $4^{\text {a }}$ semana a monocamada, totalmente confluente, foi dissociada mecanicamente e em seguida, realizada a eletroforese em gel de poliacrilamida a $7,5 \%$ das amostras provenientes dos frascos de cultura, na concentração de $40 \mu \mathrm{g}$ cada, em presença de sulfato dodecil de sódio (SDS). Os 
géis foram transferidos por eletroforese em uma cuba contendo tampão de transferência para membranas PDVF (Hybond-P), overnight, a $4^{\circ} \mathrm{C}$ com voltagem de $100 \mu \mathrm{A}$.

Com isso a membrana adquiriu a réplica da separação de moléculas em SDSPAGE. Em seguida a membrana foi cortada e bloqueada por uma hora em temperatura ambiente com PBS-T com leite em pó a 5\%. Após o bloqueio, o fragmento das membranas onde o marcador indicou o peso molecular esperado para as bandas da ECA foi incubado em $5 \mathrm{~mL}$ de anticorpo policlonal Y1 anti-ECA (1:1000) da classe IgG de camundongo em PBS-T com leite em pó a $5 \%$ a $4{ }^{\circ} \mathrm{C}$ overnight com agitação orbital fraca. Os outros fragmentos da membrana onde 0 marcador indicou o peso molecular esperado para as bandas da $\beta$-actina, foram incubados em $5 \mathrm{~mL}$ de anticorpo policlonal anti- $\beta$-actina (1:1000) da classe IgG de camundongo em PBS-T com leite em pó a $5 \%$, a $4{ }^{\circ} \mathrm{C}$ overnight com agitação orbital fraca.

Após esse período de incubação as membranas foram lavadas 5 vezes com $10 \mathrm{~mL}$ de PBS-T por 5 minutos cada lavagem. Após a lavagem, as membranas foram incubadas com o anticorpo secundário anti-lgG de camundongo peroxidase diluído em PBS-T com leite em pó a 5\%, em temperatura ambiente por um período de 2 horas, com agitação orbital fraca. Ao final das duas horas as membranas foram novamente lavadas 5 vezes com $10 \mathrm{~mL}$ de PBS-T por 5 minutos cada lavagem. A revelação foi realizada com ECL (Amersham) utilizando $1 \mathrm{~mL}$ da solução A e $25 \mu \mathrm{L}$ da solução $B$, e exposto por 20 minutos em filme. Após a exposição foi feita a revelação do filme.

\subsection{Análises estatísticas}

Para se compreender a variabilidade da variável número de colônias, utilizamos a Análise de Variância (ANOVA). As diferenças significativas entre as culturas foram realizadas através do teste Tukey-Kramer, considerando-se estatisticamente significativo $\mathrm{P}<0.05$. O teste $\mathrm{t}$ Student (paramétrico) também será utilizado na análise da celularidade, número de CFU-GM e de células aderentes na CLLD. 


\section{RESULTADOS}

\section{PARTE I - Presença da ECA nas CLLD e na medula óssea de animais WT}

\subsection{Microscopia confocal}

Os resultados podem ser visualizados na figura $6 \mathrm{~A}$. A imagem mostra a ECA em células provenientes da medula óssea de camundongos WT e cultivadas de acordo com o sistema de cultura descrito por Dexter et al. (1977). Estas imagens dão suporte para os resultados obtidos nos estudos fluorimétricos, em que observamos a atividade catalítica da ECA nas culturas, além dos ensaios de RT-PCR em tempo real e western blotting, os quais permitiram quantificar os níveis de mRNA e expressão protéica da enzima, respectivamente, neste mesmo sistema de cultivo celular.
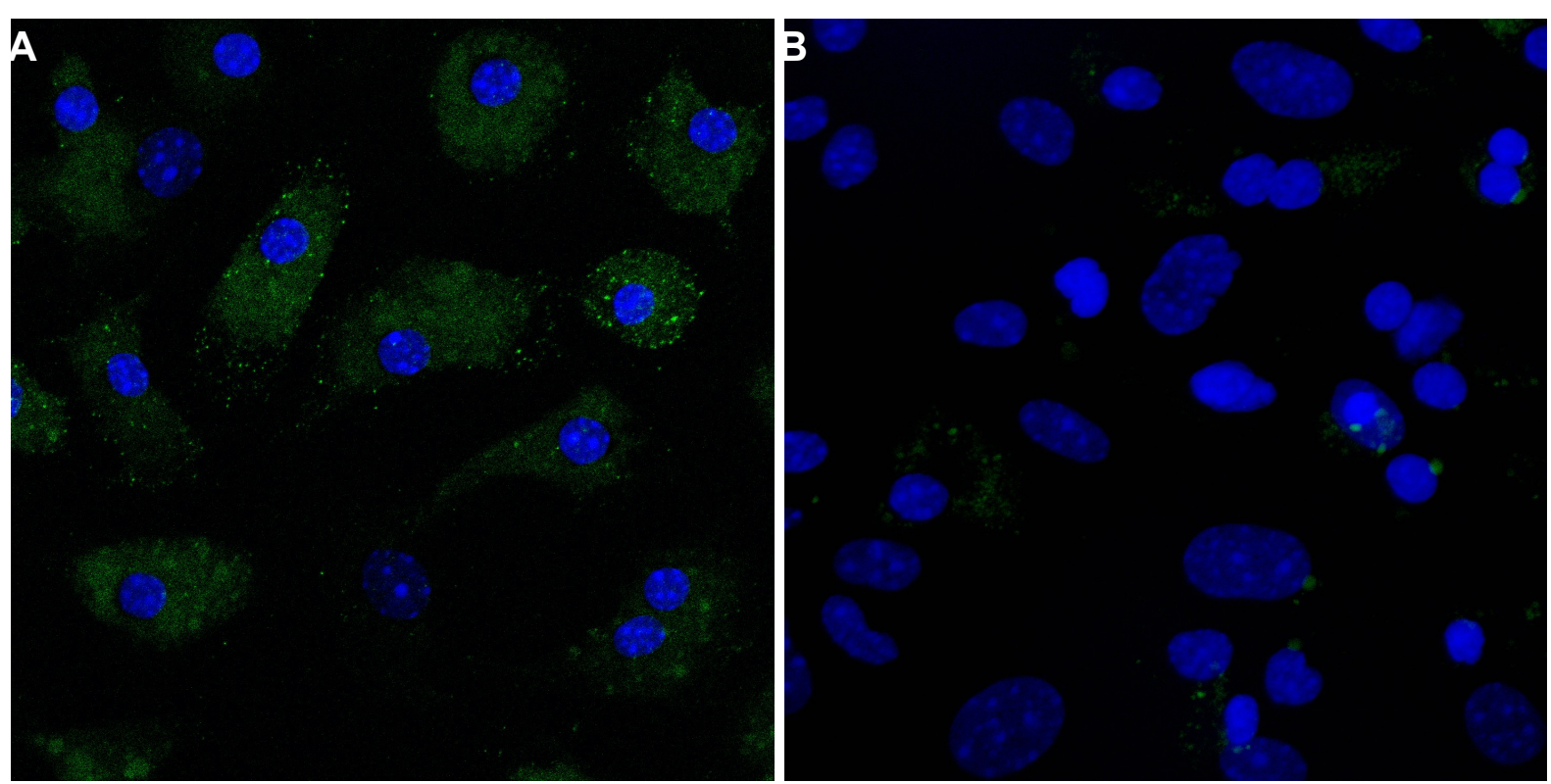

Figura 6 - (A) Localização da ECA em CLLD de camundongos WT. Fotomicrografia de fluorescência confocal de células de CLLD imunomarcadas com anticorpo imunoespecífico anti-ECA. (B) Imagem de autofluorescência - controle da fluorescência. 


\subsection{Avaliação da expressão gênica da ECA nas CLLD e na medula óssea de animais WT através de RT-PCR em tempo real}

Para quantificarmos a expressão da ECA tanto na medula óssea dos animais WT, assim como nas CLLD obtidas de células da medula óssea de animais da mesma linhagem, o mRNA total foi extraído e submetido à técnica de RT-PCR em tempo real. Como pode ser observado, tanto na medula óssea como nas células provenientes das CLLD os níveis de mRNA da ECA foram detectados. Os resultados estão expressos em unidades arbitrárias (Figura 7).

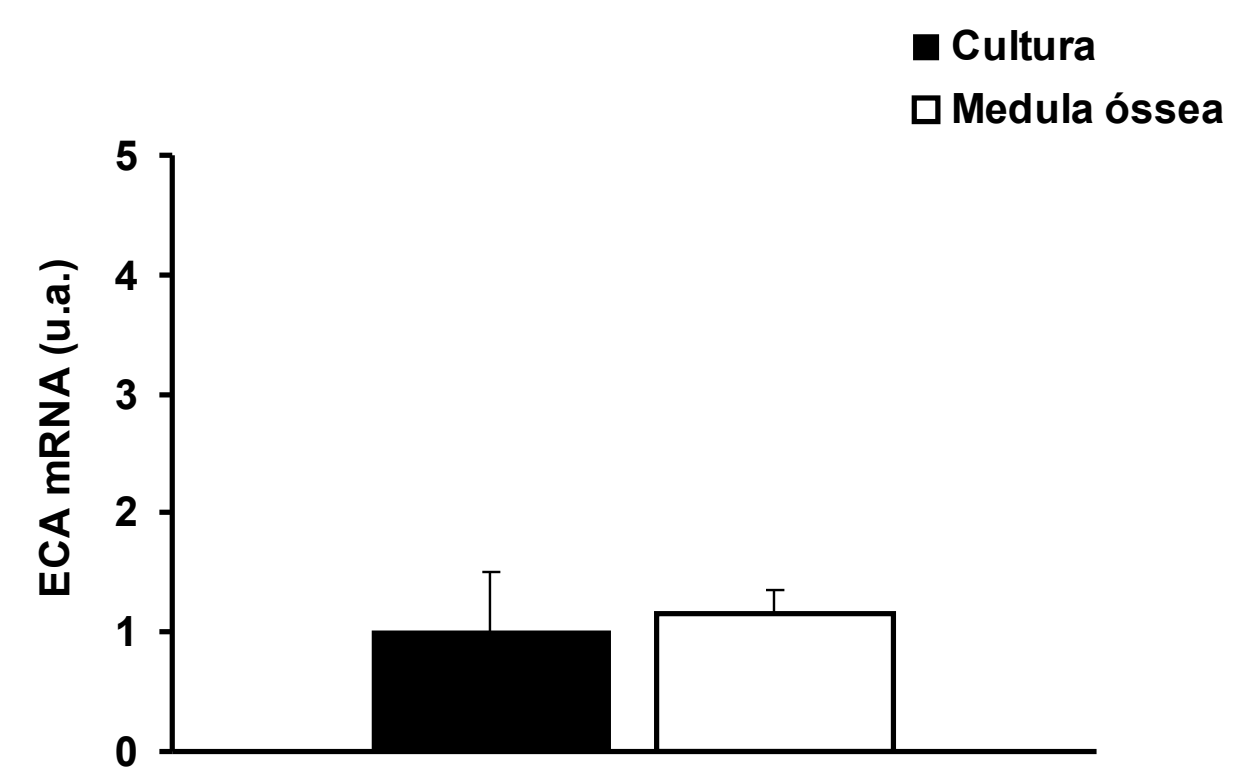

Figura 7 - Expressão relativa do mRNA da ECA em unidades arbitrárias a partir da medula óssea e de CLLD obtidas a partir de células da medula óssea de animais WT. 


\subsection{Avaliação da atividade enzimática da ECA nas CLLD e na medula óssea dos animais WT}

A análise da atividade enzimática da ECA, tanto nas CLLD assim como na medula óssea dos animais WT, mostrou a presença da enzima neste tecido medular (Figura 8). Tanto as culturas como os animais não foram submetidos a nenhum tratamento prévio.

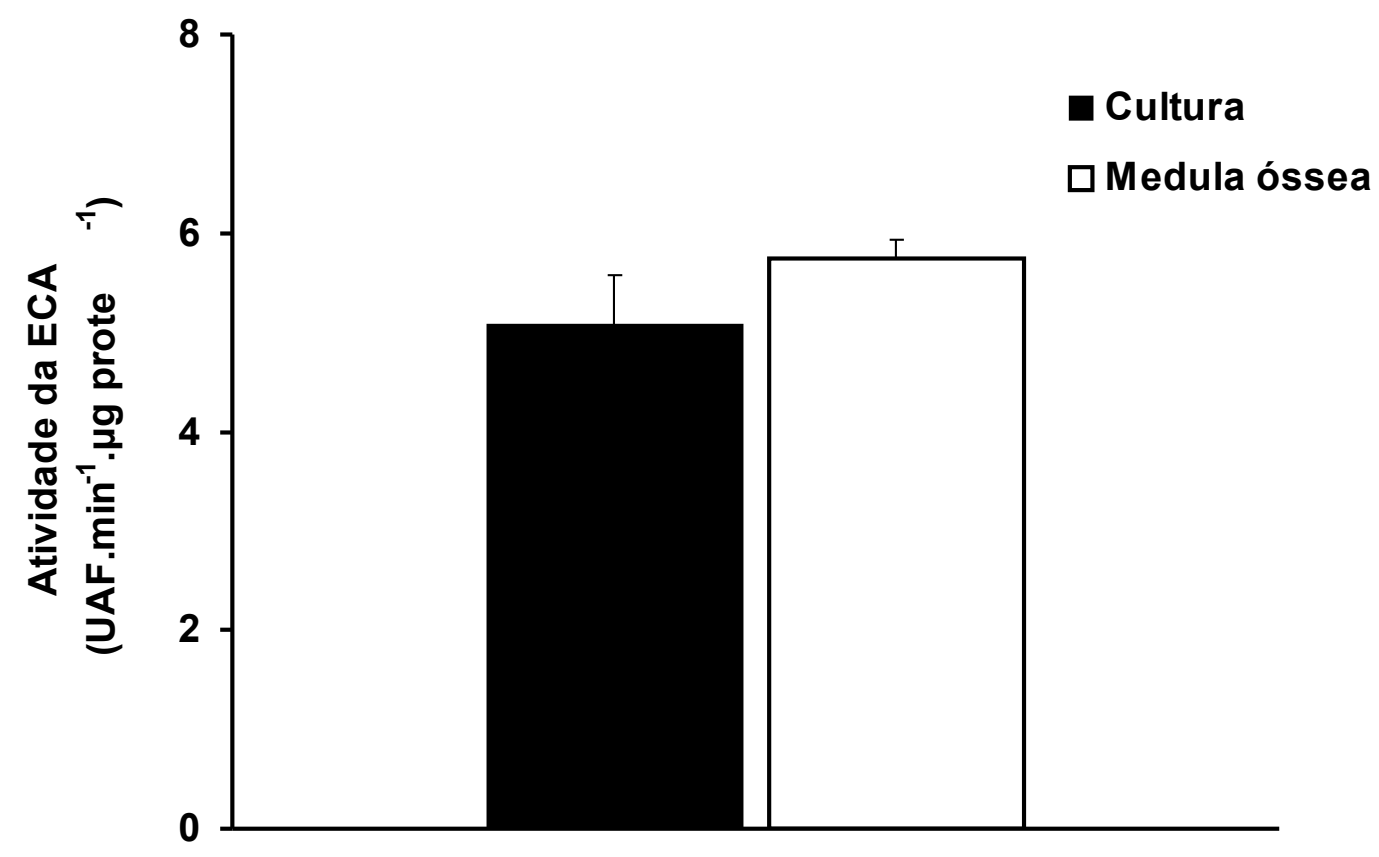

Figura 8 - Atividade da ECA em células obtidas da medula óssea e em CLLD obtidas a partir de células da medula óssea de animais WT. A atividade enzimática foi determinada espectrofluorimetricamente. Para substrato da ECA, utilizou-se o substrato fluorogênico Abz-YRK(Dnp)P-OH. 


\section{PARTE II - Papel do AcSDKP na regulação hematopoética e modulação da expressão gênica da ECA}

\subsection{Tratamento das CLLD com AcSDKP e captopril e realização de ensaios clonogênicos em soft-ágar a partir de células sobrenadantes das CLLD}

Neste ensaio foram determinados parâmetros como a celularidade aderente e não-aderente das CLLD, após o tratamento das culturas com AcSDKP (1 ПM), captopril $(1 \mu \mathrm{M})$ e salina (controle), bem como a capacidade proliferativa das culturas através da técnica de ensaios clonogênicos em soft-ágar para granulócitos e macrófagos (CFU-GM). Neste sentido, as células viáveis capazes de receber estímulos proliferativos e gerar clones foram coletadas e contadas após a $5^{\mathrm{a}}$ e $6^{\mathrm{a}}$ semanas de cultivo. Estas células foram posteriormente avaliadas através da técnica de CFU-GM. Deste modo, podemos observar na figura 9, uma redução significativa $(P<0.05)$ na celularidade não-aderente das culturas tratadas com AcSDKP e captopril. Resultados similares foram observados após a quantificação de precursores hematopoéticos através de CFU-GM, nas $5^{\mathrm{a}}$ e $6^{\mathrm{a}}$ semanas de cultivo. Este dado corrobora as evidências de que o aumento de AcSDKP, diretamente ou através da inibição da ECA no tecido medular, está relacionado a um maior número de células quiescentes no estroma medular. Por outro lado, na figura 10 podemos observar um aumento no número de células aderentes obtidas na $6^{\text {a }}$ semana de cultivo $(P<0.05)$, nas culturas expostas ao AcSDKP e captopril em relação ao controle tratado apenas com salina. Sugerindo assim um maior número de células quiescentes aderidas ao estroma medular, como descrito anteriormente. Nossos resultados mostraram não apenas o efeito regulador direto do AcSDKP na formação de CFU-GM, mas também a importância da inibição da ECA pelo captopril evitando assim, uma possível degradação do AcSDKP (Figura 11). 


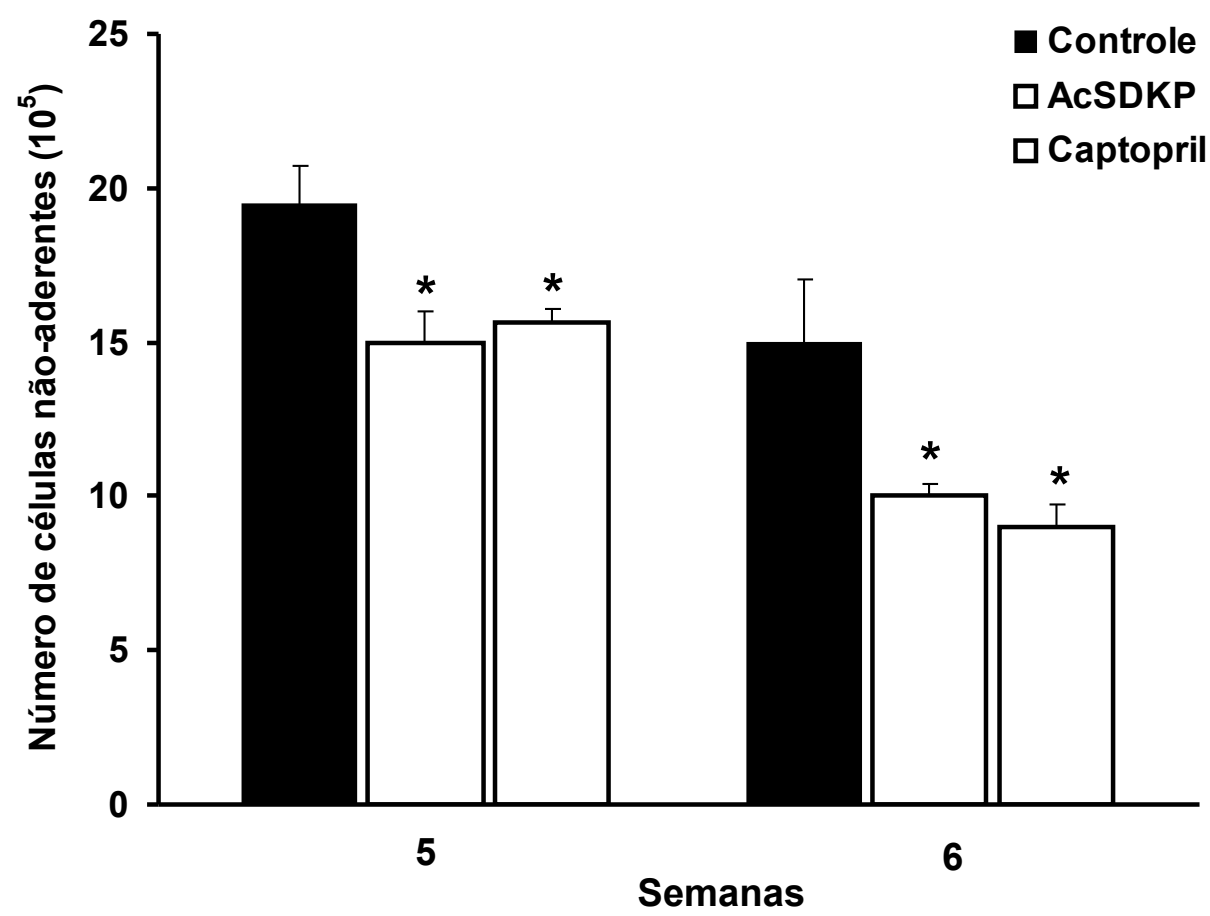

Figura 9 - Número de células não-aderentes (viáveis) obtidas nas $5^{\mathrm{a}}$ e $6^{\mathrm{a}}$ semanas, a partir do sobrenadante das CLLD obtidas a partir de células da medula óssea de animais WT e tratadas com AcSDKP (1 nM). O meio saturado foi trocado semanalmente contendo os compostos acima. $\left({ }^{*}\right)$ Significativo em relação às culturas tratadas com salina, $\mathrm{P}<0.05$ - ANOVA; Tukey-Kramer.

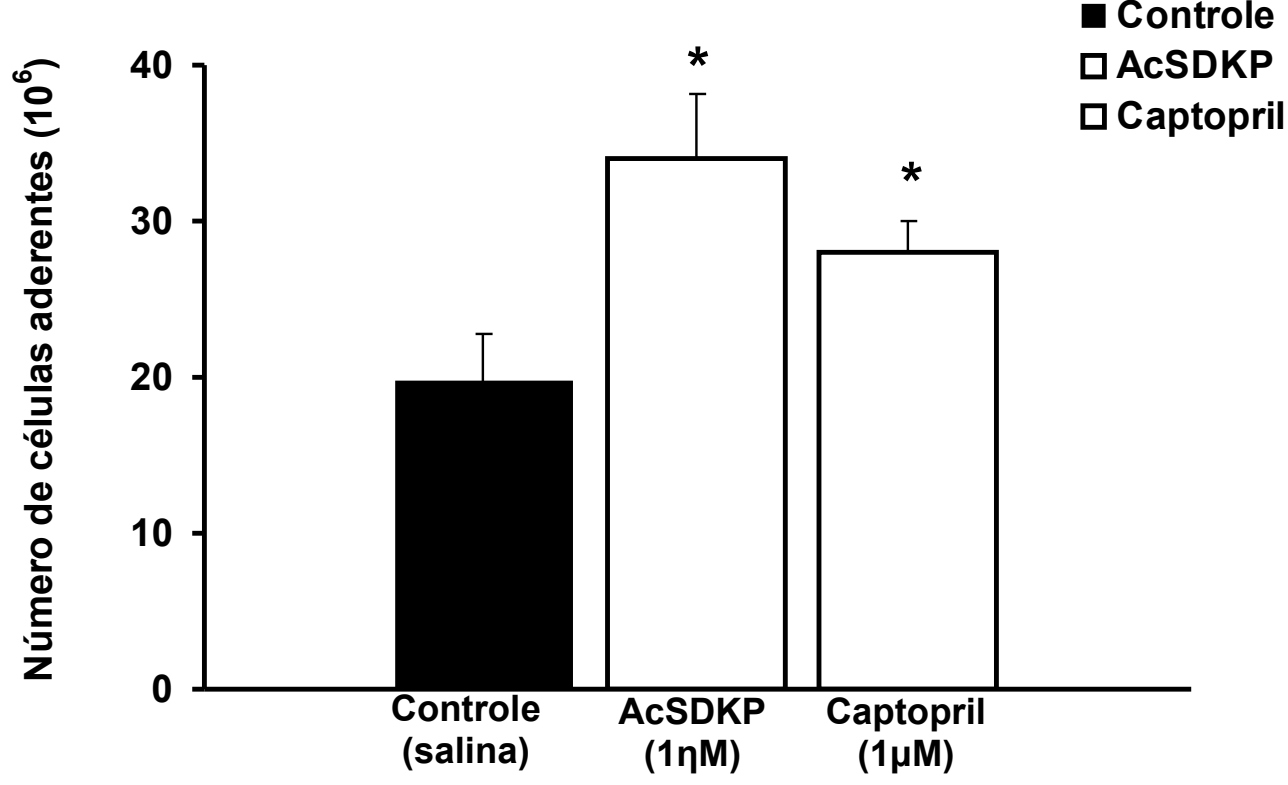

Figura 10 - Efeito dos compostos AcSDKP $(1 \eta \mathrm{M})$ e captopril $(1 \mu \mathrm{M})$ nas células aderentes dos estromas das CLLD. Avaliação realizada na $6^{a}$ semana de cultivo. $\left(^{*}\right)$ Significativo em relação às culturas tratadas com salina (controle). $\mathrm{P}<0.05-$ ANOVA; Tukey-Kramer. 


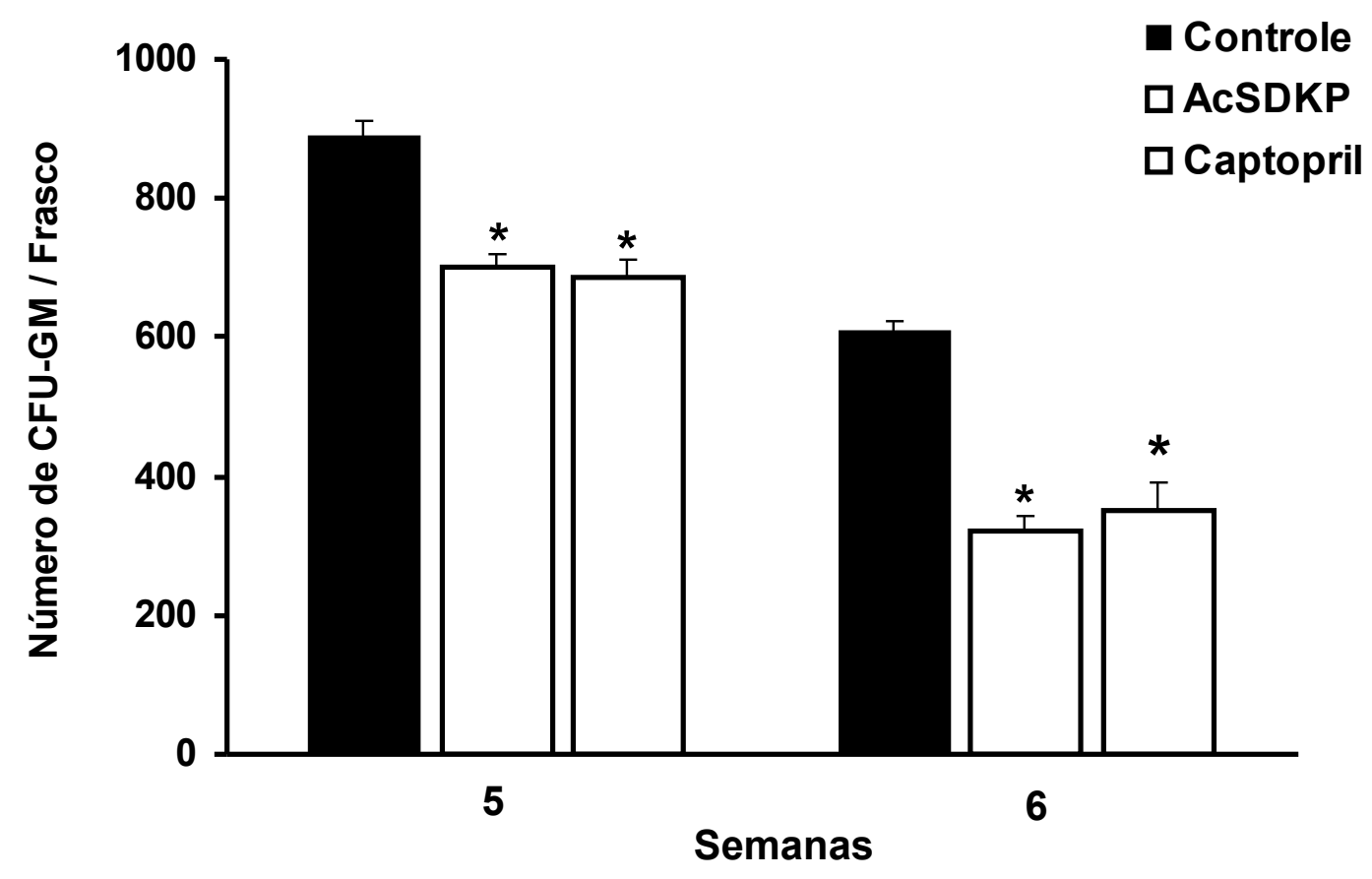

Figura 11 - Efeito do AcSDKP (1nM) na formação de CFU-GM a partir das células nãoaderentes presentes no sobrenadante das CLLD obtidas de células da medula óssea de animais WT. Avaliação iniciada na $5^{\mathrm{a}}$ semana de cultivo. ( $\left.{ }^{*}\right)$ Significativo em relação ao controle (salina). $\mathrm{P}<0.05$ - ANOVA; Tukey-Kramer.

\subsection{Ensaio clonogênico em soft-ágar a partir de células obtidas da medula óssea de animais WT tratados com AcSDKP e captopril}

Para corroborarmos a atividade regulatória negativa do AcSDKP observada in vitro, realizamos por 4 dias consecutivos, o tratamento de 3 grupos de animais WT com $10 \mu \mathrm{g}$ do peptídeo, $100 \mathrm{mg} / \mathrm{kg}$ de captopril e salina por via subcutânea. De acordo com a figura 12, podemos observar redução significativa $(P<0.05)$ no número de CFU-GM nos animais tratados com AcSDKP e captopril sugerindo tanto as participações direta do peptídeo na hematorregulação negativa, como a indireta do captopril ao inibir a ECA, provavelmente evitando a degradação do AcSDKP. 


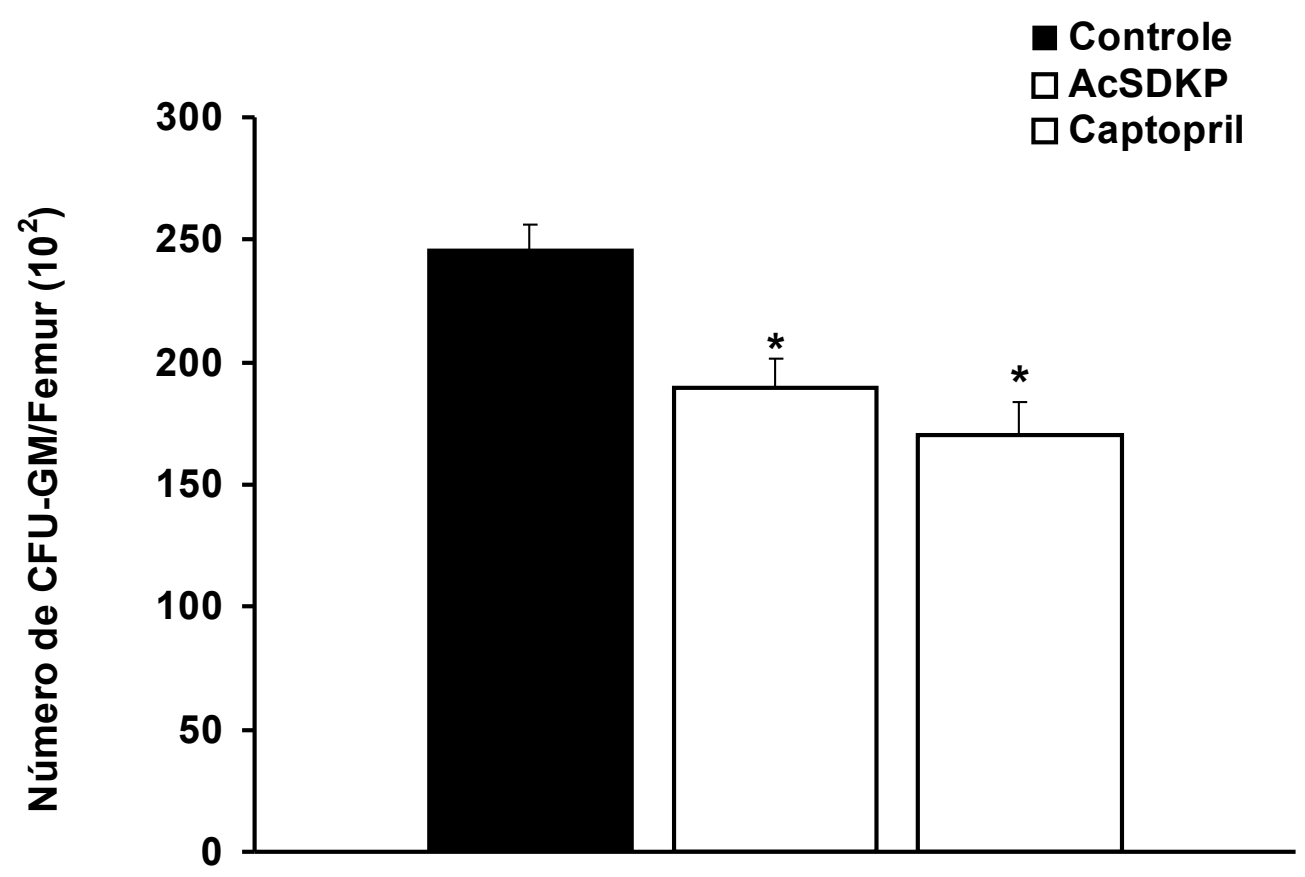

Figura 12 - Efeito dos compostos AcSDKP (10 $\mu \mathrm{g})$ e captopril $(100 \mathrm{mg} / \mathrm{kg})$ na formação de colônias de precursores hematopoéticos para granulócitos e macrófagos (CFUGM) obtidos a partir de células da medula óssea de animais WT submetidos ao tratamento por via subcutânea $(n=5)$. $\left(^{*}\right)$ Significativo em relação ao controle (salina). $\mathrm{P}<0.05$ - ANOVA; Tukey-Kramer.

\subsection{Avaliacao da expressão gênica da ECA através de RT-PCR em tempo real nas CLLD tratadas com AcSDKP}

Para avaliar a expressão gênica da ECA nas CLLD tratadas com AcSDKP, utilizamos a técnica de RT-PCR em tempo real. Neste ensaio, podemos observar na figura 13, que o mRNA da ECA, apresentou-se significativamente aumentado $(P<0.05)$ nas CLLD tratadas com AcSDKP na concentracao de 3nM. A figura também mostra que a maior concentração testada $(5 \eta \mathrm{M})$ inibiu a expressão da gênica da ECA de modo significativo nas CLLD, sugerindo que os níveis de AcSDKP podem influenciar na expressão gênica da ECA. 


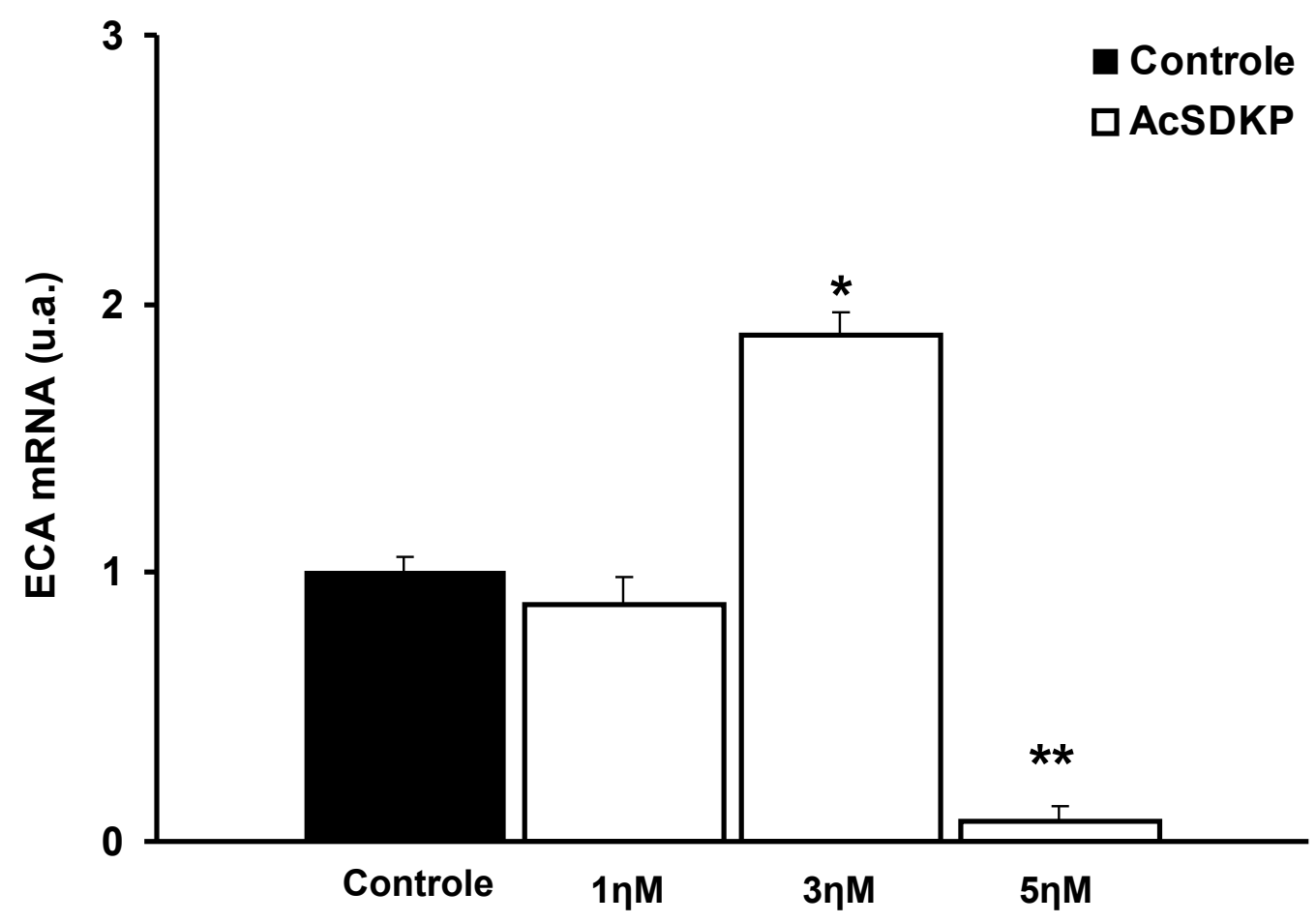

Figura 13 - Expressão relativa do mRNA da ECA em unidades arbitrárias a partir de CLLD obtidas a partir da medula óssea de camundongos WT. O tratamento com as diferentes concentrações de AcSDKP aumentaram significativamente os níveis de mRNA da ECA nas culturas. $\left({ }^{*}\right),\left({ }^{* *}\right)$ Significativo em relação ao controle. $P<0.05-$ ANOVA; Tukey-Kramer. 
PARTE III - Presença dos receptores B1 e B2 e influência dos agonistas DBK e LBK na atividade enzimática e expressão gênica da ECA

\subsection{Avaliação da expressão gênica dos receptores B1 e B2 de cininas através de RT-PCR em tempo real na medula óssea e nas CLLD de animais WT}

Neste ensaio utilizamos a camada aderente de células formadas nas culturas liquidas de longa duração obtidas a partir de células da medula óssea de camundongos WT, bem como a própria medula de animais da mesma linhagem. A análise do mRNA dos receptores de cininas B1 e B2 mostrou que ambos são expressos na medula óssea e nas culturas destes camundongos (Figura 14A e 14B). Podemos verificar neste estudo uma maior expressão do receptor B2 em ambas as análises.

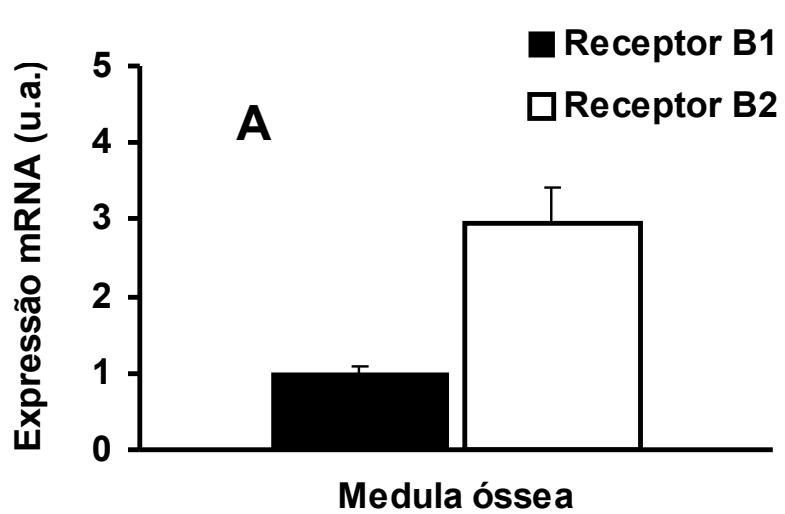

Figura 14 - (A) Expressão relativa do mRNA dos receptores de cininas B1 e B2 em unidades arbitrárias na medula óssea de camundongos WT. (B) Expressão relativa do mRNA dos receptores de cininas $B 1$ e $B 2$ em unidades arbitrárias das CLLD obtidas a partir de células da medula óssea de camundongos WT. 


\subsection{Influência do tratamento das CLLD de animais WT com agonistas de receptores de cininas DBK e LBK na atividade catalítica e na expressão gênica da ECA}

Os parâmetros avaliados neste ensaio foram a atividade da ECA e avaliação dos níveis de mRNA da ECA nas CLLD tratadas com os compostos DBK (1 $\mu \mathrm{M})$; LBK $(1 \mu \mathrm{M})$ e salina (controle).

Ao avaliarmos a atividade da ECA nas CLLD de animais WT tratados com DBK e LBK, verificamos que o tratamento com estes agonistas não altera a atividade catalítica da enzima. Em todas as situações de tratamento, a atividade enzimática mostrou-se muito semelhante ao controle sem tratamento, deixando evidente que a ativação do receptor não influência na atividade da ECA. (Figura 15).

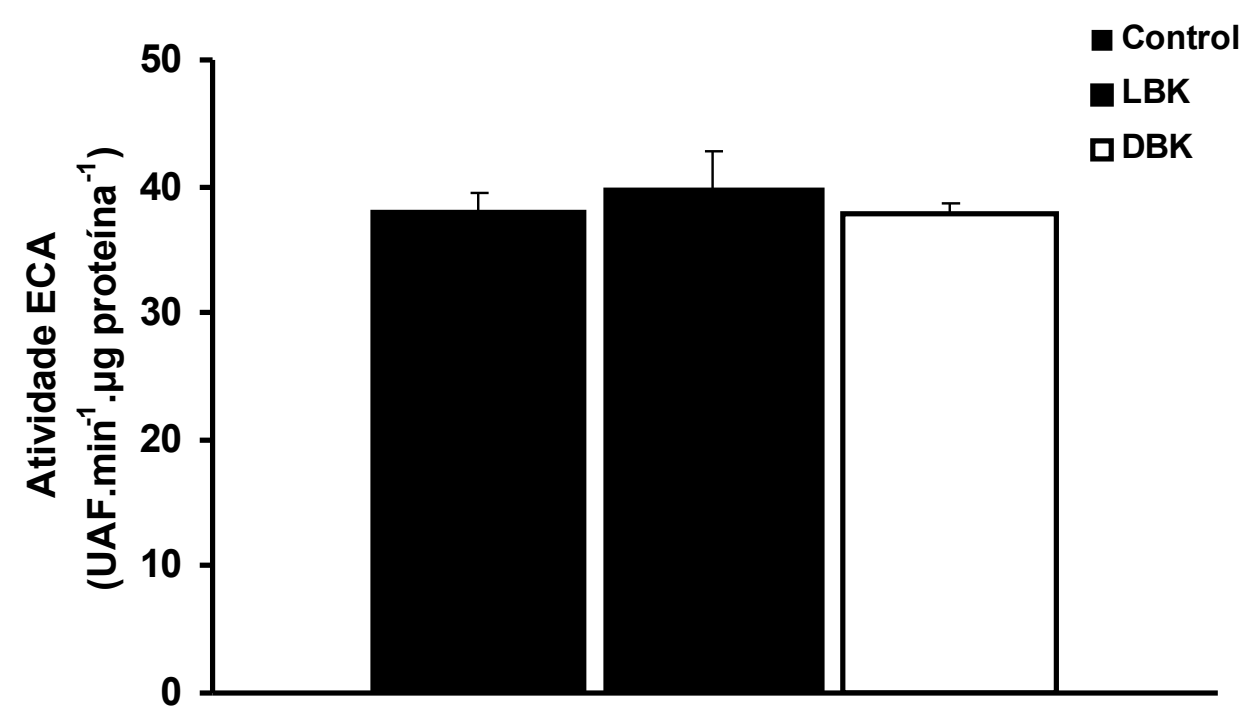

Figura 15 - Atividade da ECA nas culturas líquidas de longa duração. A atividade enzimática foi determinada espectrofluorimetricamente no final da $4^{\mathrm{a}}$ semana de cultura na presença dos compostos Lys-bradicinina (LBK) e des$\mathrm{Arg}^{9}$ bradicinina (DBK). Para substrato da ECA, utilizou-se o substrato fluorogênico Abz-YRK(Dnp)P-OH. 
Finalmente, ao avaliarmos a expressão gênica da ECA nas CLLD tratadas com DBK e LBK, observamos que os níveis de mRNA da ECA não se alteraram de modo significativo após o tratamento (Figura 16).

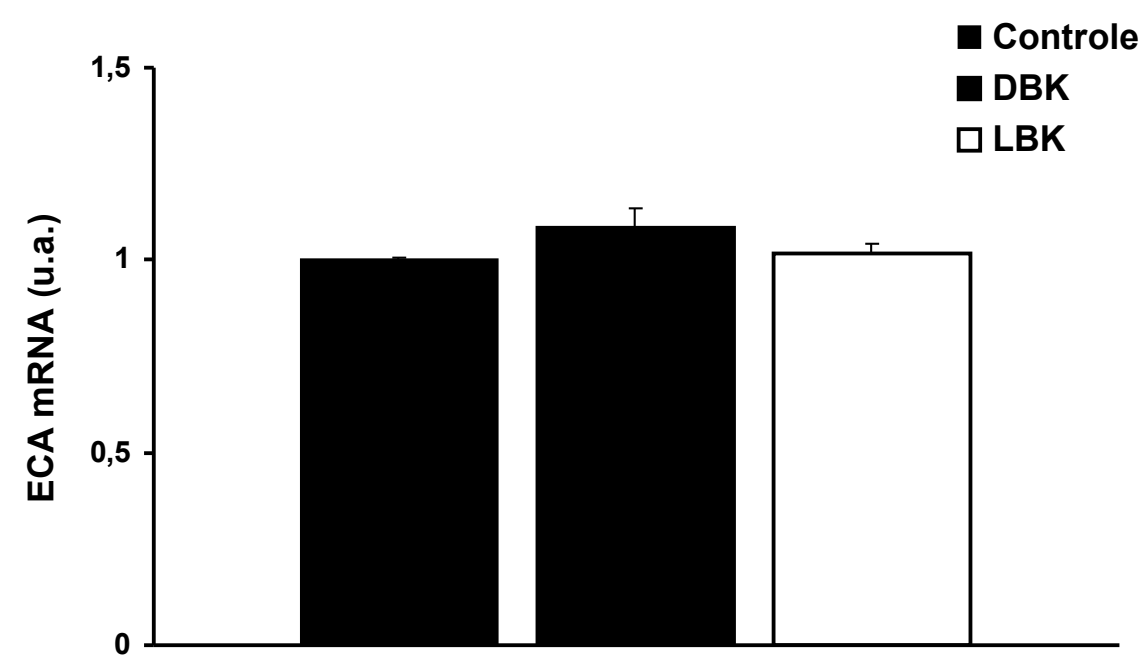

Figura 16 - Expressão relativa do mRNA da ECA em unidades arbitrárias a partir da medula óssea de camundongos WT. O tratamento com DBK e LBK não alterou os níveis de mRNA da enzima. 
PARTE IV - Papel da ECA na regulação hematopoética das CLLD de animais nocautes dos receptores $\mathrm{B} 1$ de cininas

4.9 Expressão gênica e protéica da ECA nas CLLD obtidas de células da medula óssea de animais WT e KOB1 através de RT-PCR em tempo real e western blotting

Conforme podemos verificar nas figuras $17 \mathrm{~A}$ e 17B, há uma tendência a uma maior expressão da ECA nas culturas de animais KOB1 quando comparadas aos WT, no entanto, estatisticamente, este aumento não foi significativo $(P=0,06)$. Na figura 18C, observamos a presença de mRNA da ECA nas culturas provenientes de animais KOB1. Estes dados sugerem um possível aumento, embora não significativo, da ECA nos animais geneticamente modificados em relação aos WT. 


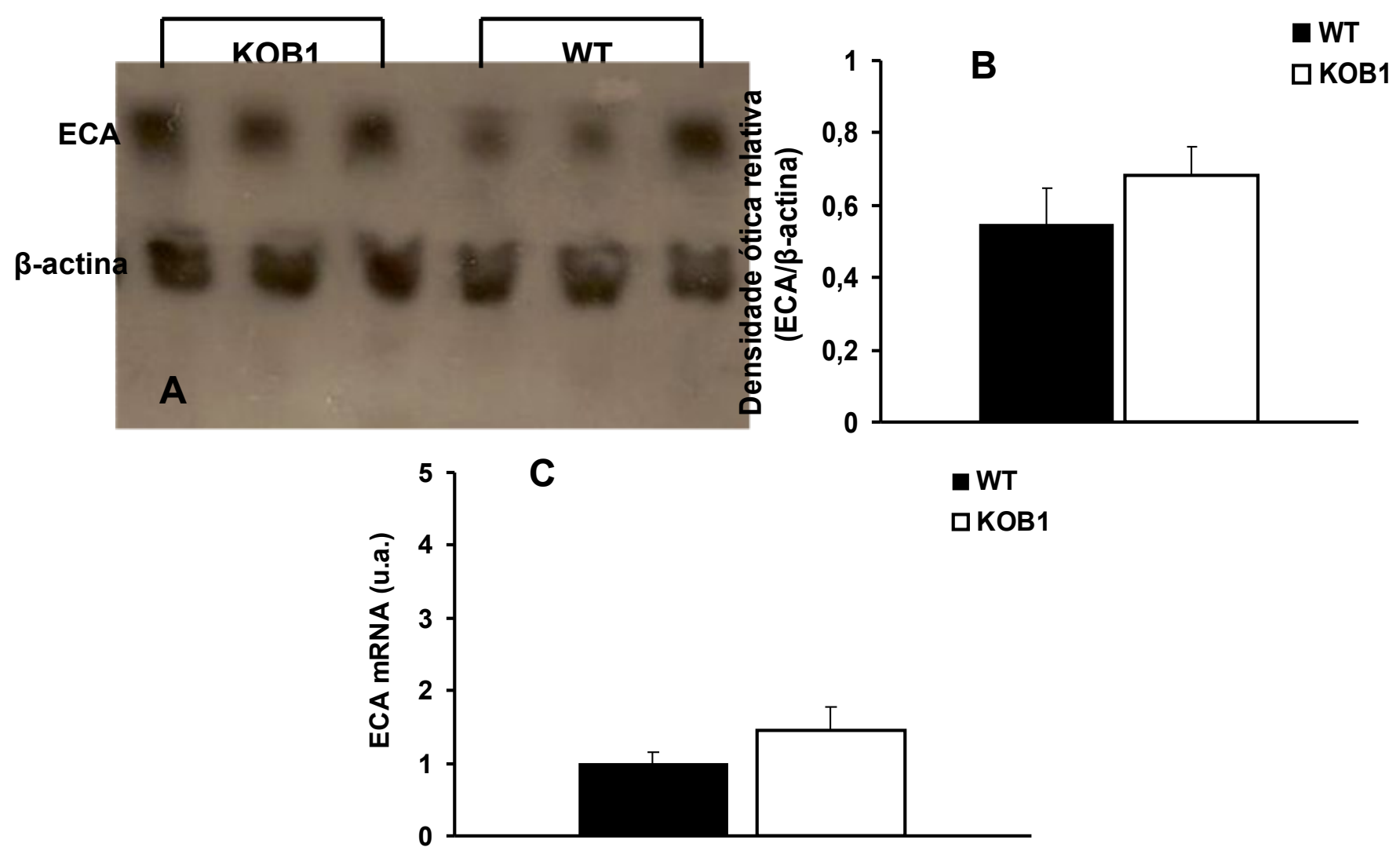

Figura 17 - (A) Western blotting das proteínas isoladas de homogenato celular das CLLD de animais WT e KOB1. As proteínas foram separadas por SDS/PAGE (gel a $7,5 \%$ ), transferidas para uma membrana de nitrocelulose e reveladas com anticorpo monoclonal contra ECA. (B) Densidade ótica relativa das bandas, entre a ECA e $\beta$-actina. Os resultados foram obtidos através do software $\angle A B W O R K S$. (C) Expressão relativa do mRNA da ECA em unidades arbitrárias em CLLD de animais WT e KOB1. 


\subsection{Imunofenotipagem de células da medula óssea de animais WT e KOB1 e determinação das populações que expressam a ECA}

A figura 18 mostra a análise realizada através de citometria de fluxo em células da medula óssea de animais WT e KOB1 associada à marcação com anticorpos anti-ECA para murinos revelou que populações estromais, ou seja, células não-hematopoéticas, expressaram a ECA. Populações celulares onde estariam inseridas as células hematopoéticas praticamente não expressaram a ECA.

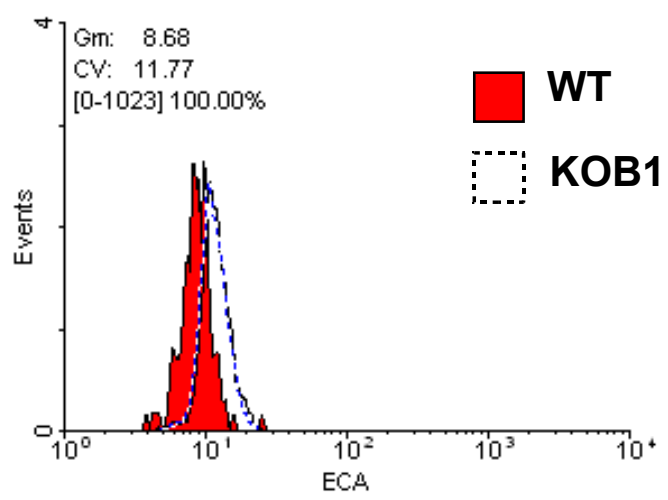

Figura 18 - Histograma da análise de células da medula óssea de animais WT e KOB1 que foram submetidas à imunofenotipagem e marcadas simultaneamente com antiECA murino. As células da medula óssea foram coletadas e os seguintes marcadores de superfície foram utilizados: CD45 e Ter119. Não houve diferença significativa entre os animais WT e KOB1em relação à expressão da ECA. A porcentagem de células da medula óssea foi realizada no citômetro de fluxo FACsCalibur (Becton Dickinson, CA, USA) e as análises feitas através do programa WinMDI. 


\subsection{Influência do tratamento das CLLD obtidas de células da medula óssea de animais KOB1 com AcSDKP e captopril}

Neste ensaio, após o tratamento das culturas com AcSDKP (1 $\eta \mathrm{M})$, captopril $(1 \mu \mathrm{M})$ e salina, analisamos parâmetros como celularidade não-aderente e celularidade aderente. Assim, foram coletadas e contadas semanalmente as células viáveis, visto que estas são as capazes de receber estímulos proliferativos e gerar clones, que foram posteriormente avaliados através de CFU-GM. Deste modo, tanto os animais WT como os KOB1, apresentaram redução da população de células nãoaderentes nas semanas avaliadas em ambos os tratamentos. No entanto, ao observamos a celularidade não-aderente das culturas dos animais KOB1 tratados com AcSDKP, podemos observar uma maior resistência ao tratamento realizado se compararmos a contagem destes animais com os WT na $5^{a}$ semana, já que neste período da avaliação, a redução da celularidade não-aderente não é significativa em relação ao mesmo período dos animais WT (Figuras 19A e 19B). Já o tratamento com captopril reduziu de modo significativo a celularidade não-aderente das culturas obtidas dos animais WT e KOB1. Na figura $19 \mathrm{C}$, podemos observar o comparativo da celularidade não-aderente na $5^{a}$ semana entre as culturas dos animais KOB1 e WT. Neste ensaio podemos verificar um aumento na celularidade não-aderente em animais KOB1 em relação ao controle tratado com salina.

A figura 20 nos mostra o número de células aderentes do estroma medular destas culturas. Nesta análise, observamos em todas as situações de tratamento in vitro, aumento significativo no número de células aderentes quando comparadas às culturas tratadas apenas com salina. As tabelas 1 e 2 (apêndice) mostram o número de células não-aderentes que foram liberadas para os sobrenadantes das culturas. 

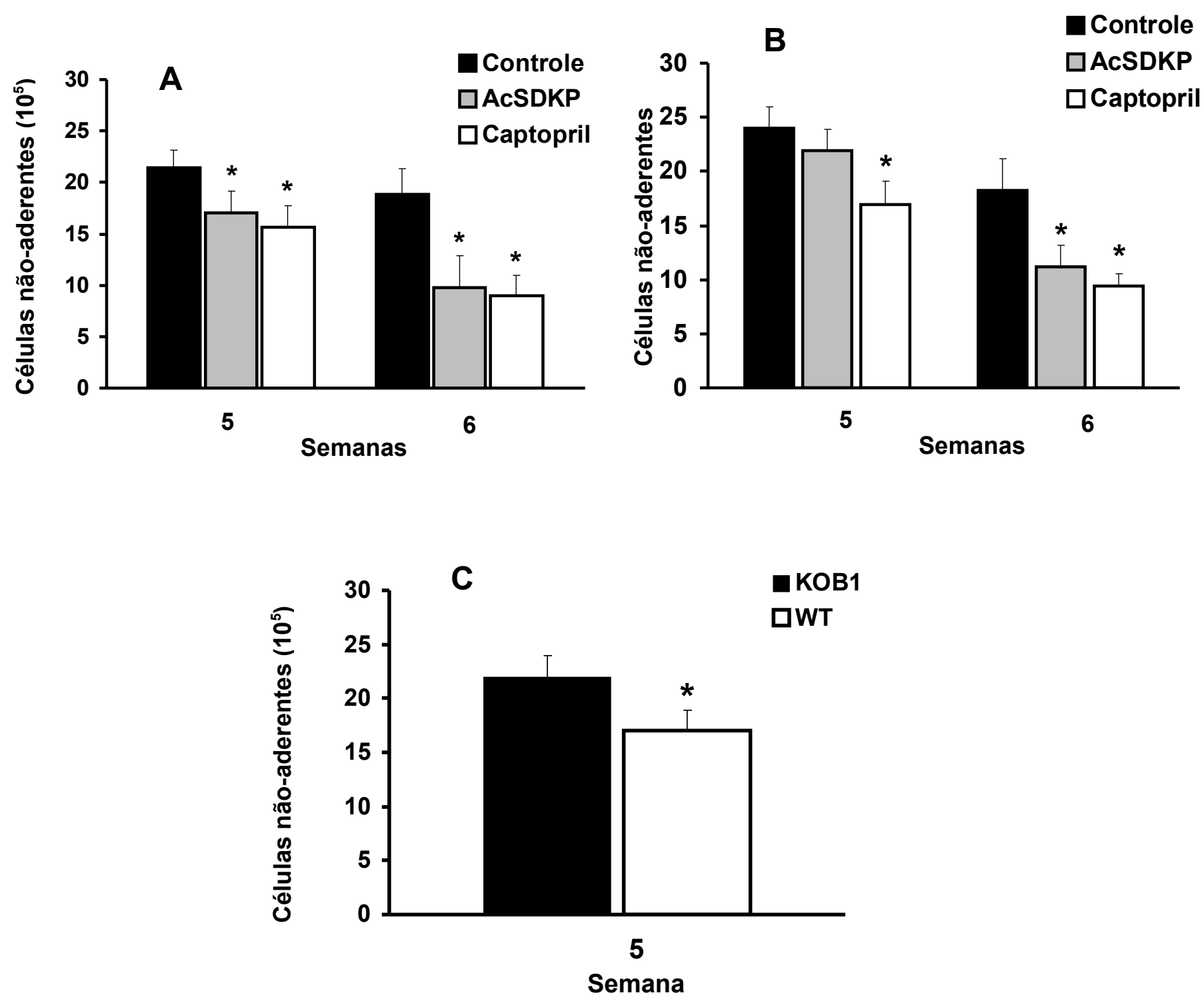

Figura 19 - (A) e (B) Número de células não-aderentes (viáveis) obtidas nas $5^{\mathrm{a}}$ e $6^{\mathrm{a}}$ semanas, a partir do sobrenadante das culturas líquidas obtidas de células da medula óssea de animais WT e KOB1, respectivamente. O meio saturado foi trocado semanalmente contendo os compostos acima e suas respectivas concentrações. $\left(^{*}\right)$ Significativo em relação às culturas tratadas com salina. $\mathrm{P}<0.05$ - ANOVA; Tukey-Kramer. (C) Comparativo da $5^{\mathrm{a}}$ semana. ( ${ }^{*}$ ) Significativo em relação às culturas obtidas de células de animais KOB1 e tratadas com AcSDKP. P<0.05 - ANOVA; Tukey-Kramer. 


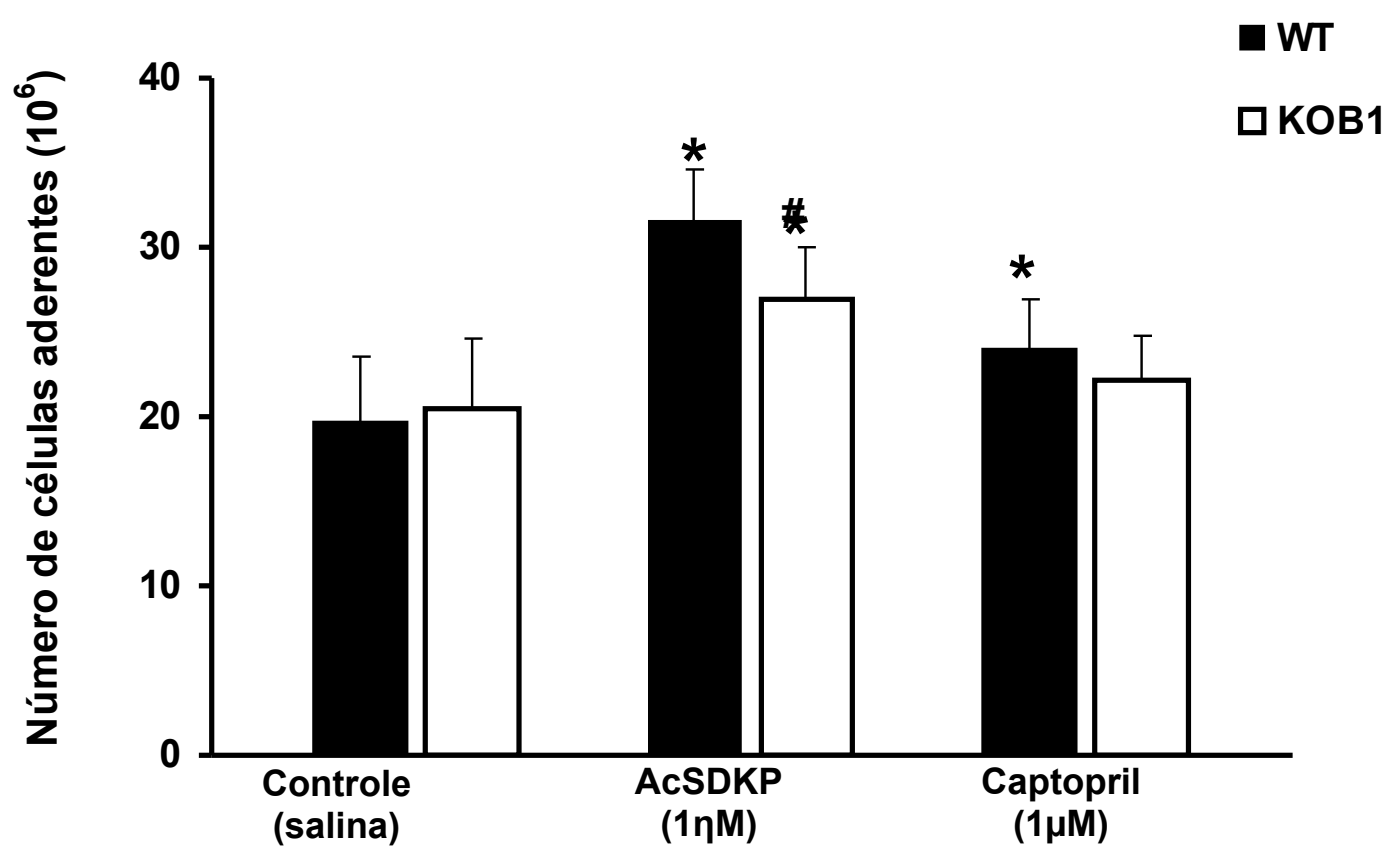

Figura 20 - Efeito do AcSDKP $(1 \eta \mathrm{M})$ e do captopril $(1 \mu \mathrm{M})$ nas células aderentes dos estromas das CLLD. Avaliação realizada na $6^{\text {a }}$ semana de cultivo. $\left({ }^{*}\right)$ Significativo em relação às CLLD tratadas com salina (controle). $P<0.05-$ ANOVA; Tukey-Kramer. (\#) Significativo em relação as CLLD de animais WT e tratadas com AcSDKP. P<0.05 - ANOVA; Tukey-Kramer. ( ) Significativo em relação às culturas tratadas com AcSDKP. P<0.05 - ANOVA; Tukey-Kramer.

\subsection{Ensaios clonogênicos em soft-ágar a partir de células obtidas do sobrenadante das CLLD de animais WT e KOB1 e tratadas com AcSDKP e captopril}

Com a finalidade de avaliarmos a capacidade proliferativa dos estromas obtidos em manter a mielopoese in vitro, realizamos ensaios clonogênicos em softágar para granulócitos e macrófagos (CFU-GM). Após a quantificação destes precursores hematopoéticos através de CFU-GM, nas $5^{\mathrm{a}}$ e $6^{\mathrm{a}}$ semanas de cultivo, nossos resultados mostraram o efeito dos compostos AcSDKP e captopril na formação de colônias CFU-GM obtidas a partir das células não-aderentes presentes no sobrenadante das culturas líquidas de animais WT, KOB1. Os resultados mostraram redução significativa na formação de CFU-GM nas culturas dos animais WT em todas as situações de tratamento $(P<0.05)$, ao contrário das culturas de 
animais KOB1, que não apresentaram redução significativa na $5^{a}$ semana e que estavam sob tratamento com AcSDKP, ocorrendo tal redução apenas na $6^{\mathrm{a}}$ semana. As culturas de animais KOB1 tratadas com captopril apresentaram redução significativa em todos os períodos. (Figura 21). Estes achados estão possivelmente associados a maior atividade catalítica da ECA descrita anteriormente nestes animais.
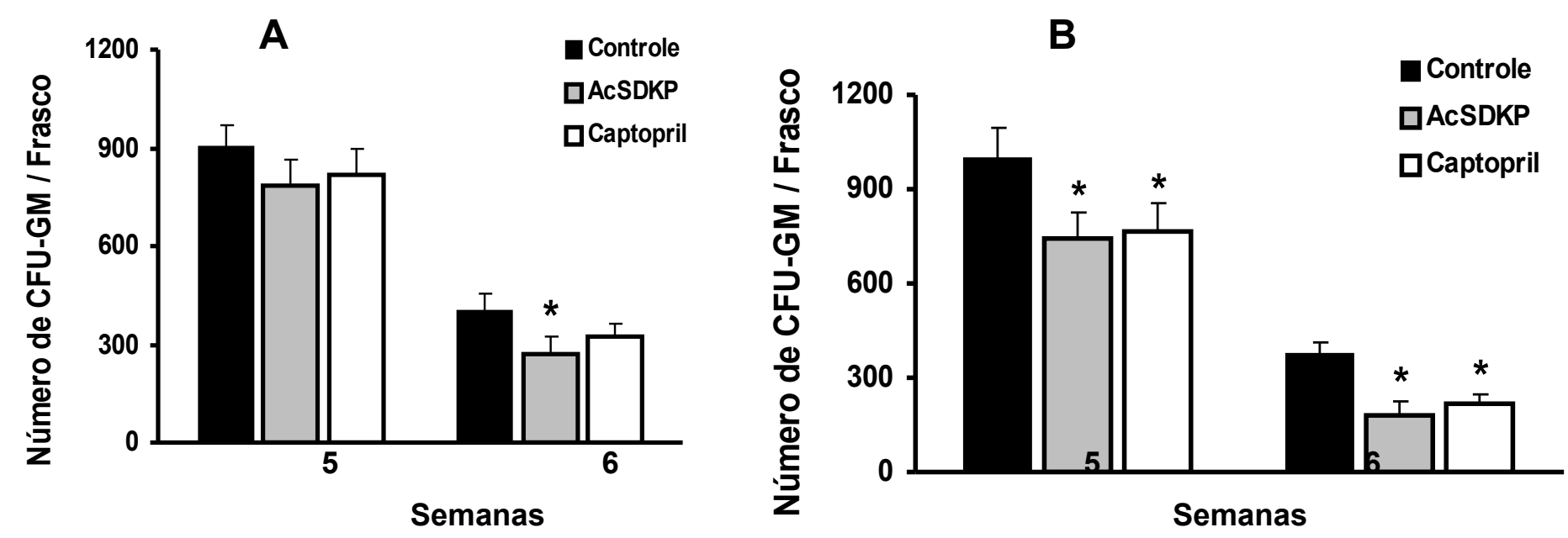

Figura 21: Efeito dos compostos AcSDKP $(1 \eta M)$ e captopril $(1 \mu \mathrm{M})$ na formação de colônias de precursores hematopoéticos para granulócitos e macrófagos (CFU-GM) obtidas a partir das células não-aderentes presentes no sobrenadante das culturas líquidas. Avaliação iniciada na $5^{a}$ semana de cultura. (A) Animais KOB1. (B) Animais WT. ( ${ }^{*}$ ) Significativo em relação ao controle (salina). $P<0.05$ - ANOVA; Tukey-Kramer. 
4.13 Imunofenotipagem de células das CLLD obtidas da medula óssea de animais WT e KOB1 e a influência do tratamento com captopril sobre as CLLD de animais KOB1

A imunofenotipagem de células das CLLD dos animais WT e KOB1 foi realizada com o objetivo de quantificarmos as populações celulares encontradas neste sistema de cultivo. Os resultados apresentaram algumas alterações na distribuição das populações hematopoéticas destas culturas. Com relação à linhagem mielóide, observamos reduções significativas na população eritróide e na população de granulócitos e macrófagos $\left(\mathrm{Gr} 1^{+} / \mathrm{Mac} 1^{+}\right)$dos animais $\mathrm{KOB} 1$ quando comparados aos animais WT $(P<0.05)$, conforme ilustrado na figura 22 e nos histogramas na figura 23.

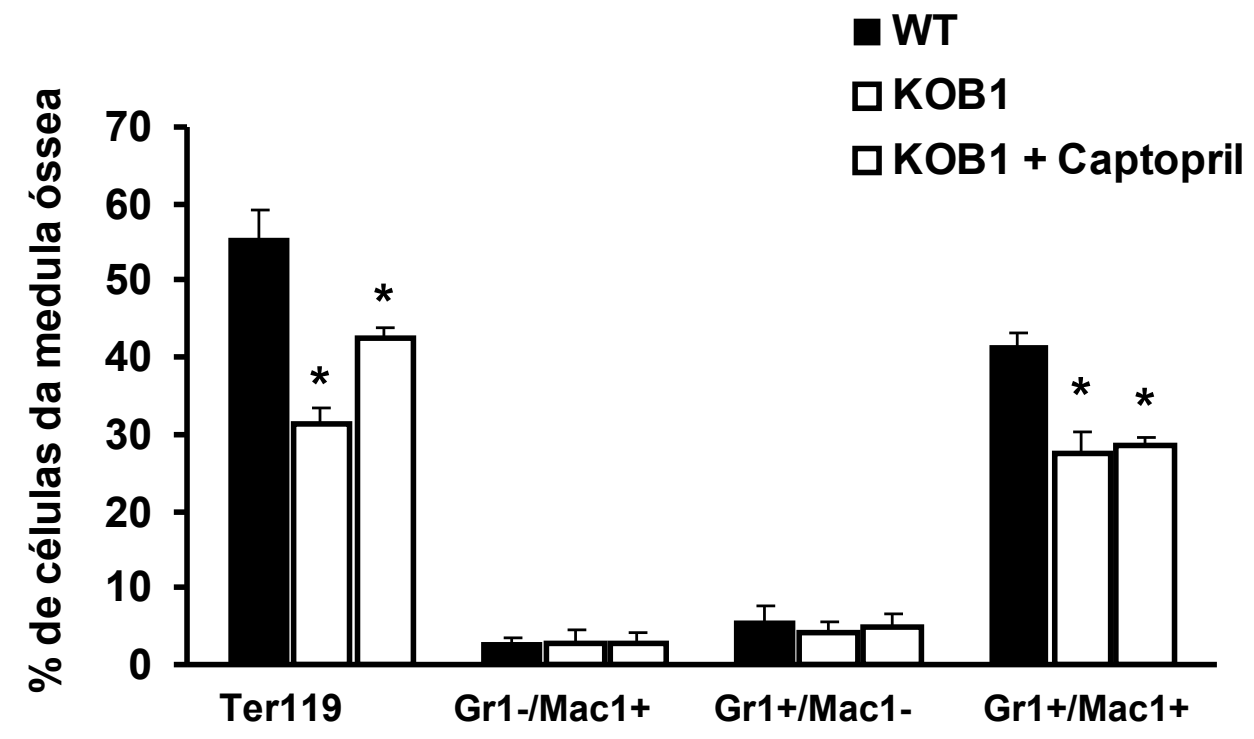

Figura 22 - Análise da porcentagem de progenitores hematopoéticos nas CLLD de animais WT e KOB1. As células da medula óssea foram coletadas e os seguintes marcadores de superfície utilizados: Gr1, Mac1 e Ter119. A porcentagem de progenitores hematopoéticos foi realizada no citômetro de fluxo FACsCalibur (Becton Dickinson, CA, USA) e as análises feitas através do programa WinMDI. $\left.{ }^{*}\right) \mathrm{P}<0.05$ - ANOVA; Tukey-Kramer. 
WT
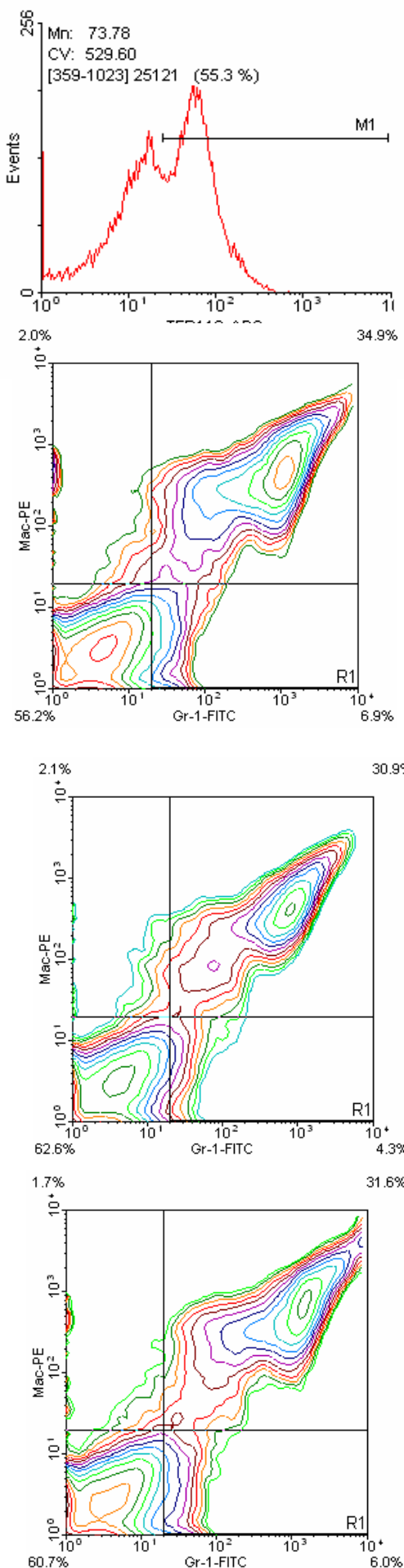

K
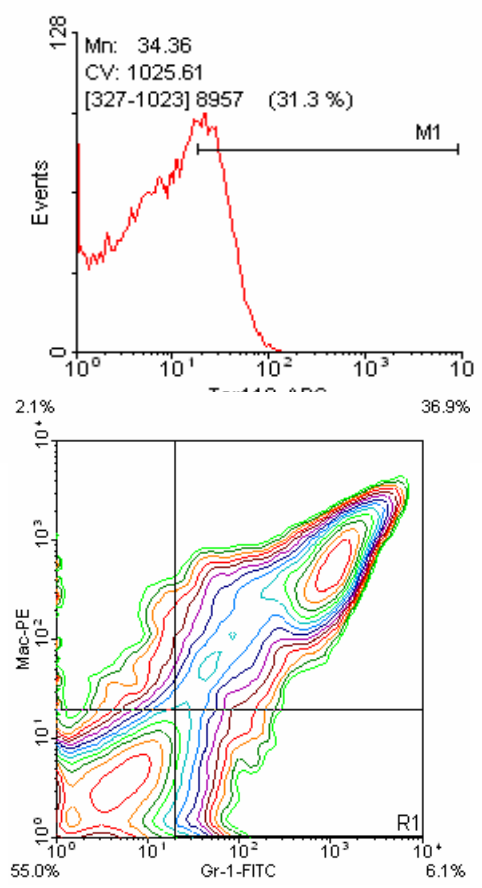

$9 \% \quad 1.9$
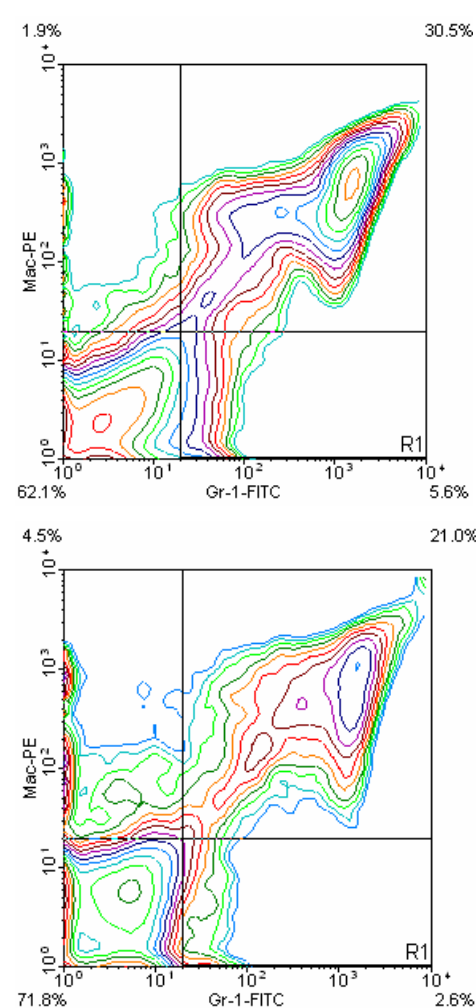
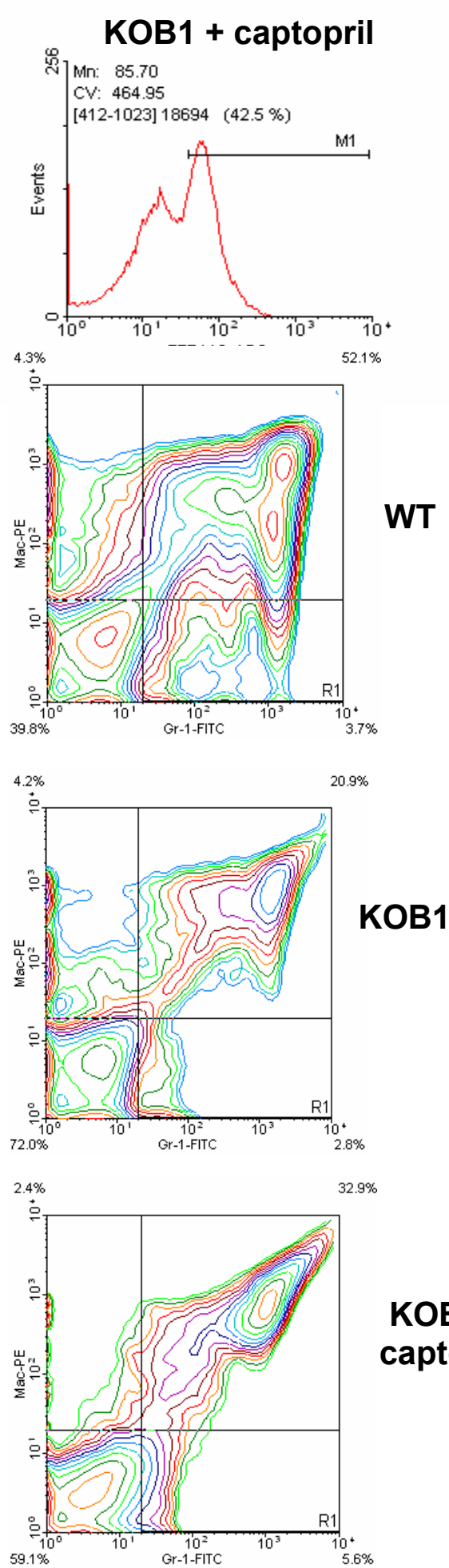

Figura 23 - Histogramas da análise de progenitores hematopoéticos nas CLLD nas CLLD de animais WT, KOB1 e KOB1 tratadas com captopril. Foram utilizados os seguintes marcadores de superfície: Gr1, Mac1 e Ter119. A porcentagem de progenitores hematopoéticos foi determinada no citômetro de fluxo FACsCalibur (Becton Dickinson, CA, USA) e as análises feitas através do programa WinMDI. 
Em relação à população de células-tronco (C-Kit+Sca1+Lin' e CKit+Sca1+Lin $\left.{ }^{\text {Low }}\right)$, verificamos uma diminuição significativa $(P<0.05)$ nas culturas de animais KOB1 em relação às culturas de animais WT. No entanto, quando realizamos $o$ tratamento das culturas de animais KOB1 com $1 \mu \mathrm{M}$ de captopril, observamos um aumento desta população (Figura 24). Abaixo os histogramas obtidos da análise pela citometria de fluxo (Figura 25)

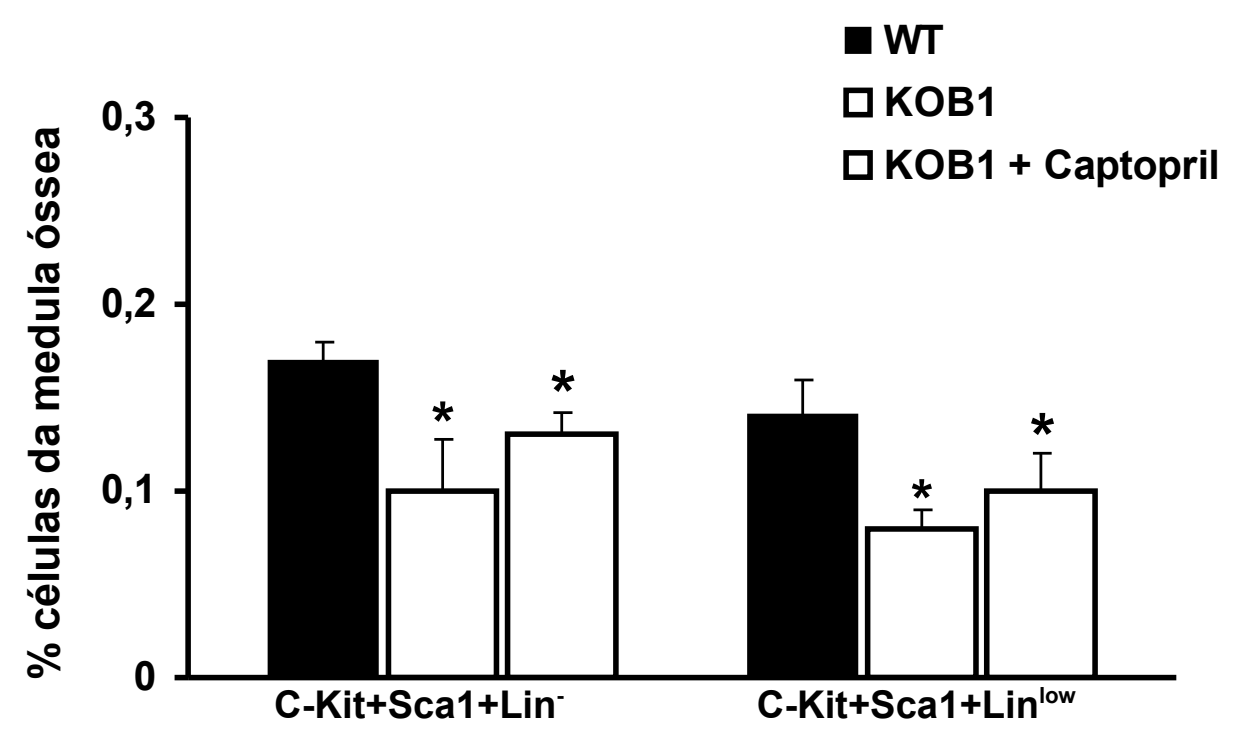

Figura 24 - Análise das células-tronco de longa e curta duração nas CLLD de animais WT, KOB1 e KOB1 tratadas com captopril. Para a imunofenotipagem foram utilizados os seguintes marcadores de superfície: C-Kit e Sca-1. A porcentagem de progenitores hematopoéticos foi determinada no citômetro de fluxo FACsCalibur (Becton Dickinson, CA, USA) e as análises feitas através do programa WinMDI. (*) $P<0.05$ - ANOVA; Tukey-Kramer. 


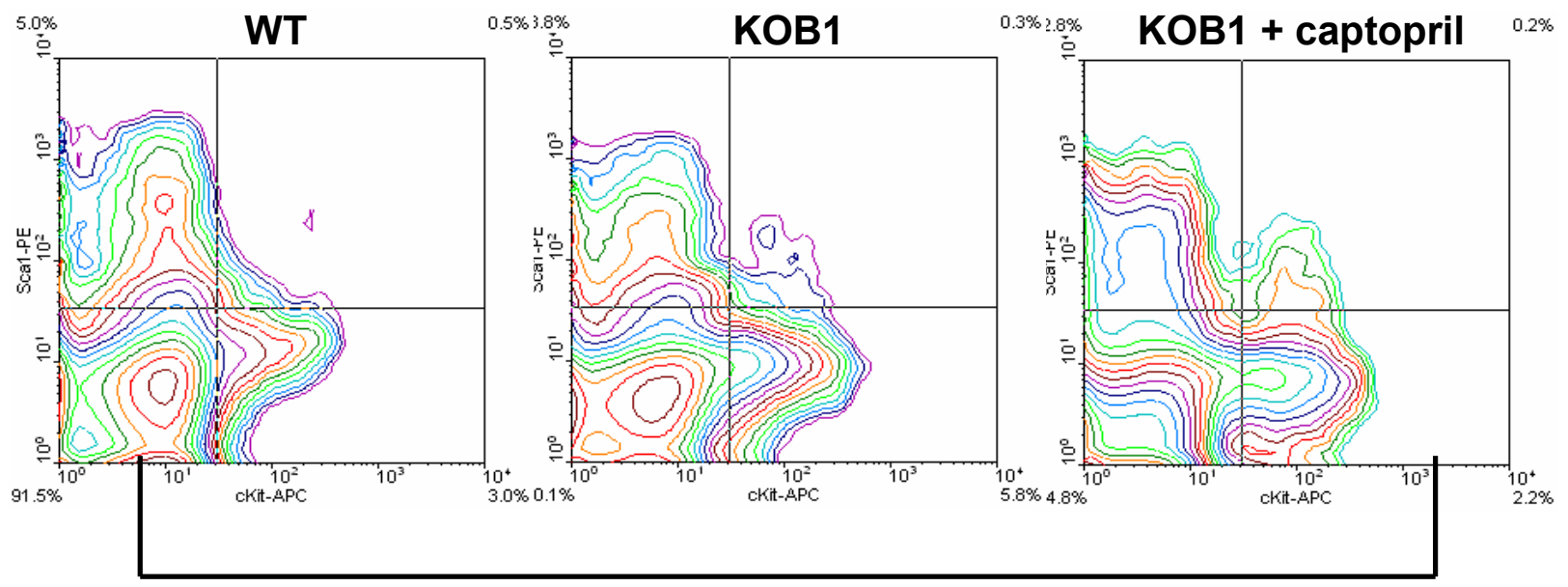

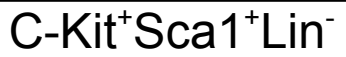

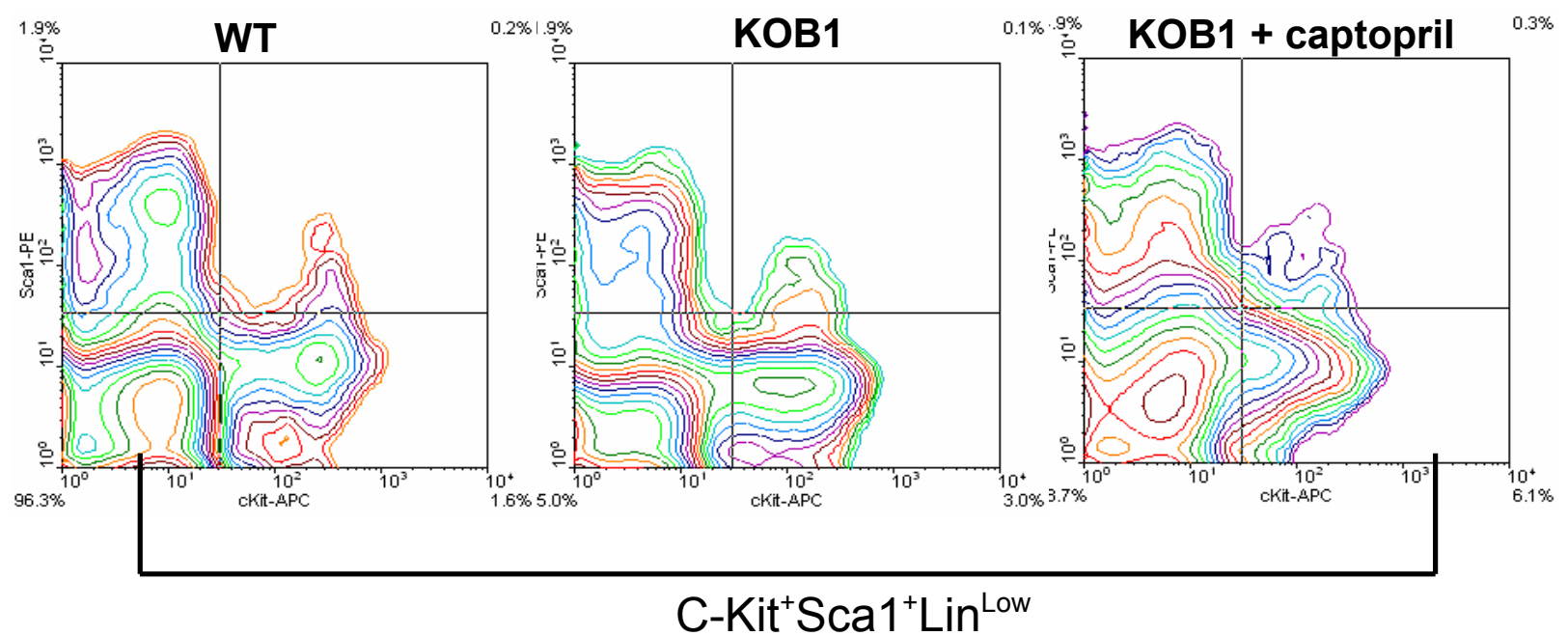

Figura 25 - Histogramas da análise de células-tronco de longa e curta duração nas CLLD de animais WT, KOB1 e KOB1 tratadas com captopril. Para a imunofenotipagem foram utilizados os seguintes marcadores de superfície: CKit e Sca-1. A porcentagem de progenitores hematopoéticos foi determinada no citômetro de fluxo FACsCalibur (Becton Dickinson, CA, USA) e as análises feitas através do programa WinMDI. 


\subsection{Influência do tratamento com AcSDKP e captopril na atividade e expressão gênica da ECA nas CLLD de animais KOB1 e WT}

A análise dos resultados mostrou que as culturas de animais WT e KOB1 tratadas com captopril apresentaram significativa redução na atividade catalítica da ECA, ao passo que as culturas tratadas com AcSDKP, apresentaram um ligeiro aumento na atividade desta enzima quando comparadas as culturas controle (salina), sugerindo um possível processo de regulação por parte do microambiente hematopoético destes animais na presença do tetrapeptídeo AcSDKP quando fornecido a este sistema de cultura de maneira crônica (Figura 26A).

Para avaliar a expressão gênica da ECA nas culturas tratadas com AcSDKP, utilizamos a técnica de RT-PCR em tempo real. Neste ensaio, observamos que o mRNA da ECA, apresentou-se aumentado nas culturas de animais WT tratadas com AcSDKP (figura 26B), ao contrário das culturas de animais KOB1.

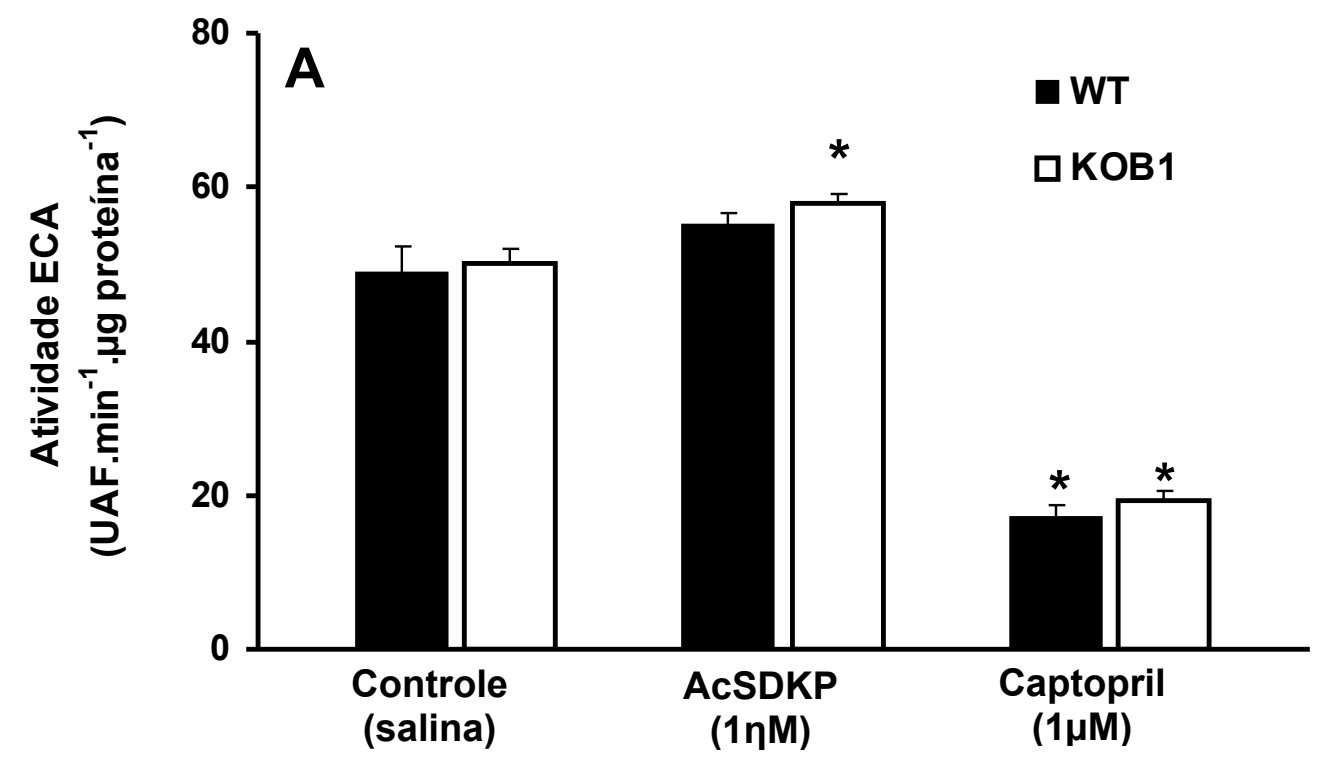




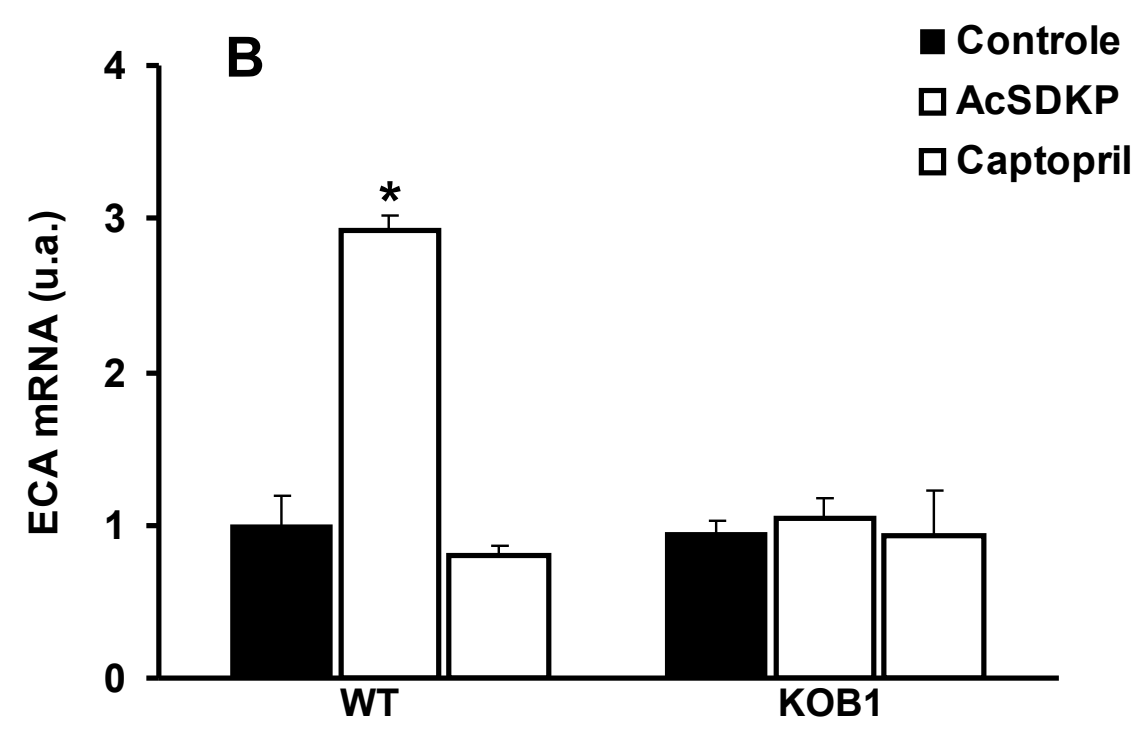

Figura 26 - (A) Atividade da ECA nas CLLD tratadas com salina, AcSDKP (1 ฤM) e captopril $(1 \mu \mathrm{M})$. A atividade enzimática foi determinada espectrofluorimetricamente. Para substrato da ECA, utilizou-se o substrato fluorogênico Abz-YRK(Dnp)P$\mathrm{OH} .\left(^{*}\right)$ Diferenças significativas em relação ao controle. $\mathrm{P}<0.05$ - ANOVA, Tukey-Kramer. (B) Expressão relativa do mRNA da ECA em unidades arbitrárias a partir de CLLD obtidas de medula óssea de camundongos WT e KOB1. $\left(^{*}\right)$ Diferenças significativas em relação ao controle (salina). $\mathrm{P}<0.05$ ANOVA, Tukey-Kramer.

\subsection{Quantificação dos níveis de AcSDKP nas CLLD obtidas da medula óssea de animais WT e KOB1 e tratadas com captopril}

Os resultados obtidos mostraram aumento significativo $(\mathrm{P}<0.05)$ nos níveis de AcSDKP encontrados no meio condicionado das CLLD tratadas com captopril $(1 \mu \mathrm{M})$ quando comparado às culturas tratadas com salina. (Figura 28). As concentrações de AcSDKP foram determinadas a partir da curva-padrão apresentada na figura 27. 


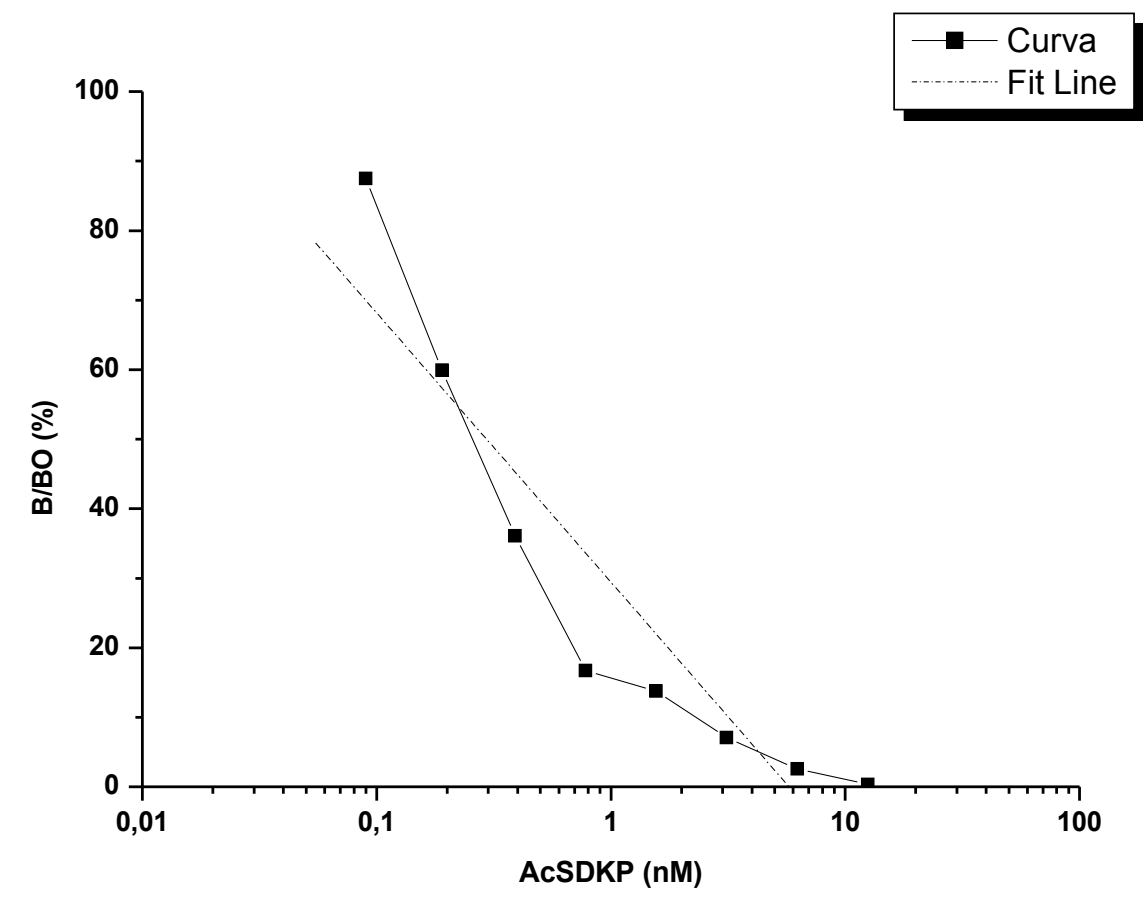

Figura 27 - Curva padrão para determinação das concentrações de AcSDKP no meio condicionado CCLD submetidas aos diferentes tratamentos.

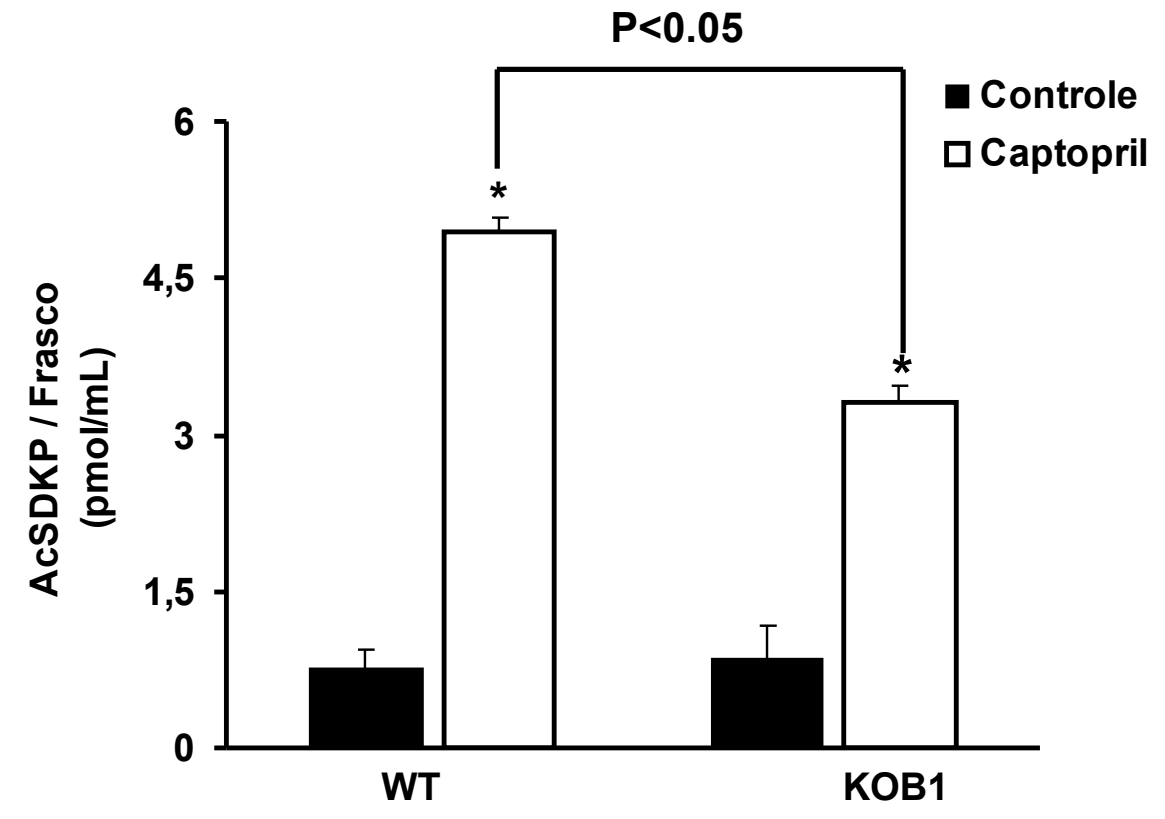

Figura 28 - Níveis de AcSDKP no meio condicionado das CLLD de animais WT e KOB1. O tratamento das culturas foi realizado semanalmente juntamente com a troca por meio fresco. As culturas foram tratadas com salina e captopril $(1 \mu \mathrm{M})$. $\left(^{*}\right)$ Diferença significativa em relação ao controle (salina) $\mathrm{P}<0.05$ - ANOVA, TukeyKramer. 


\subsection{Influência dos compostos AcSDKP e captopril sobre o ciclo celular de células sobrenadantes das CLLD de animais WT e KOB1}

A análise realizada através de citometria de fluxo indica que tanto o AcSDKP como o captopril, podem interferir na porcentagem de células que se encontram na fase $S$ do ciclo celular. A figura 29 mostra que o tratamento com ambos os compostos fez aumentar significativamente $(P<0.05)$ o número de células em fase $S$ em relação ao controle (salina). Além disso, podemos observar que as CLLD dos animais KOB1 tratadas com captopril apresentaram redução significativa $(P<0.05)$ na porcentagem de celulas em fase $S$ quando comparadas às culturas tratadas com AcSDKP. Abaixo são representados os histogramas da análise (Figura 30).

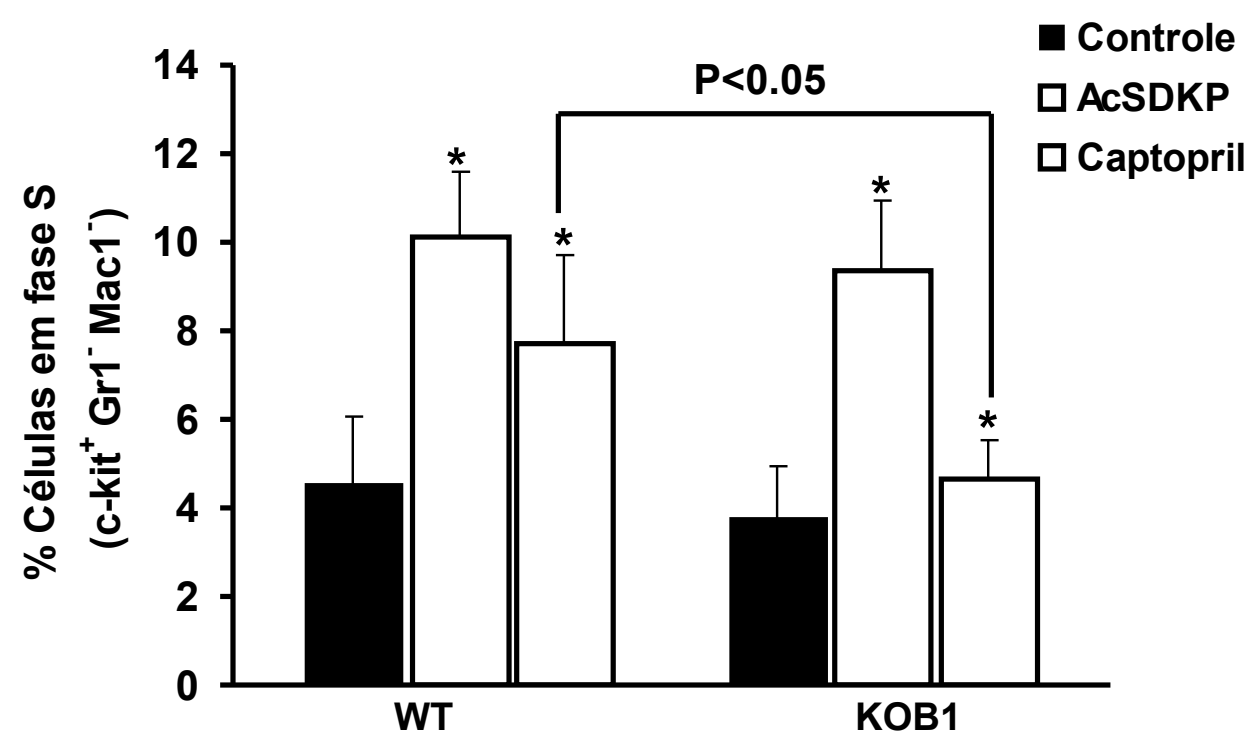

Figura 29 - Efeito do AcSDKP (1ฤM) e do captopril $(1 \mu \mathrm{M})$ na porcentagem de células (c-kit ${ }^{+}$ $\mathrm{Gr} 1^{-} \mathrm{Mac1}^{-}$) em fase $S$ do ciclo celular nas CLLD. (*) Diferenças significativas em relação ao controle (salina), $\mathrm{P}<0.05$ - ANOVA, Tukey-Kramer. 

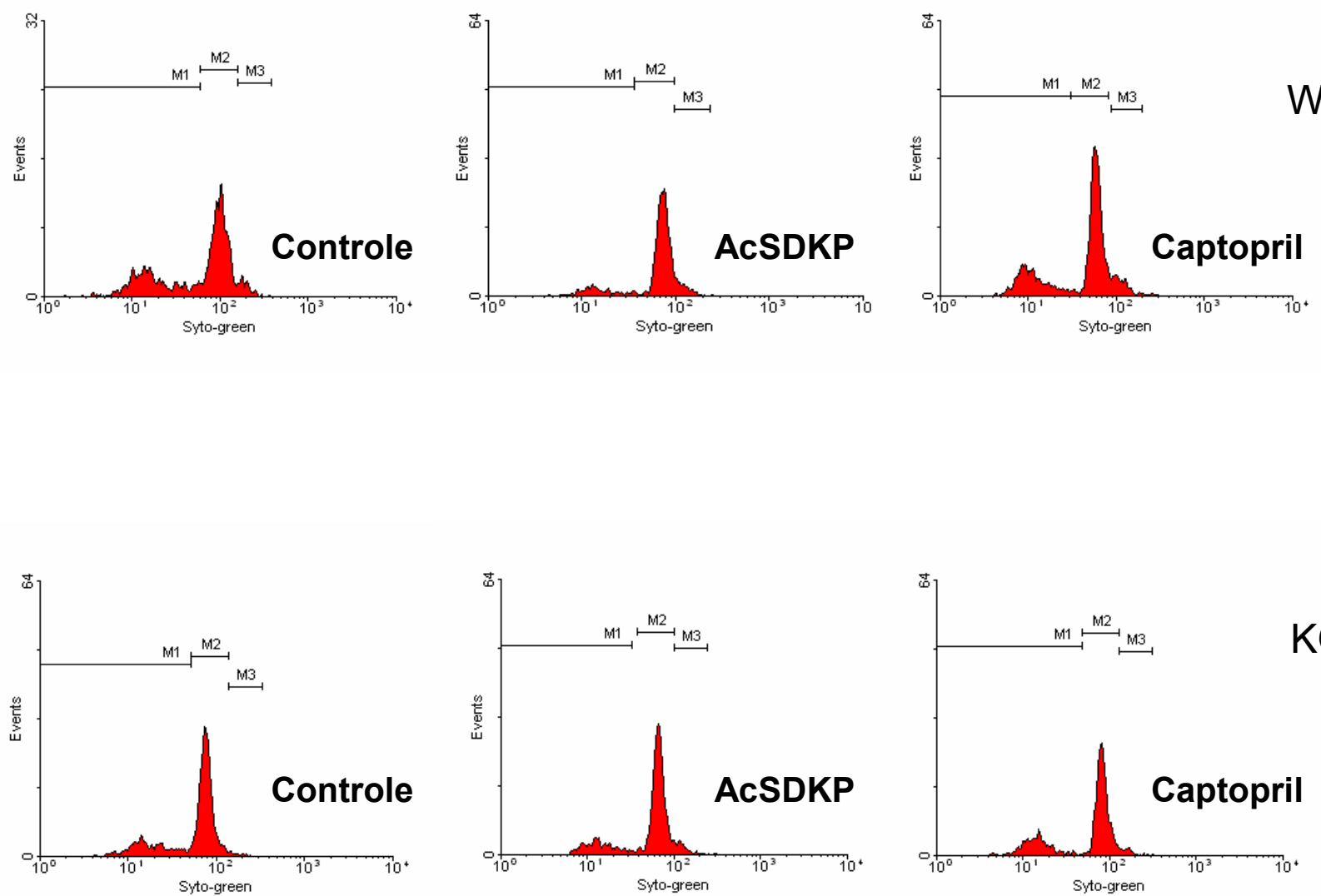

Figura 30 - Histogramas do conteúdo de DNA por "syto-green". Leitura realizada no detector FL1. Células de CLLD de animais WT e KOB1 tratadas com AcSDKP $(1 \eta \mathrm{M})$, captopril $(1 \mu \mathrm{M})$ e salina (controle).

\subsection{Ensaio clonogênico em soft-ágar a partir de células obtidas da medula óssea de animais WT e KOB1 tratados com AcSDKP e captopril}

Novamente a atividade regulatória do AcSDKP sobre a proliferação e diferenciação de CFU-GM foi observada. Ao realizarmos o tratamento dos animais WT e KOB1 com $10 \mu \mathrm{g}$ de AcSDKP, 100mg/kg de captopril e salina, por via subcutânea, por 4 dias consecutivos, observarmos, conforme mostra a figura 31, uma redução significativa $(\mathrm{P}<0.05)$ no número de $C F U-G M$ nos animais tratados com AcSDKP e captopril se comparados ao tratamento com salina (controle). Ainda sobre a figura 31 , ao compararmos o número de CFU-GM após o tratamento com 
AcSDKP em ambos os animais WT e KOB1, podemos verificar que a redução de CFU-GM foi significativamente menor nos animais KOB1 $(P<0.05)$.

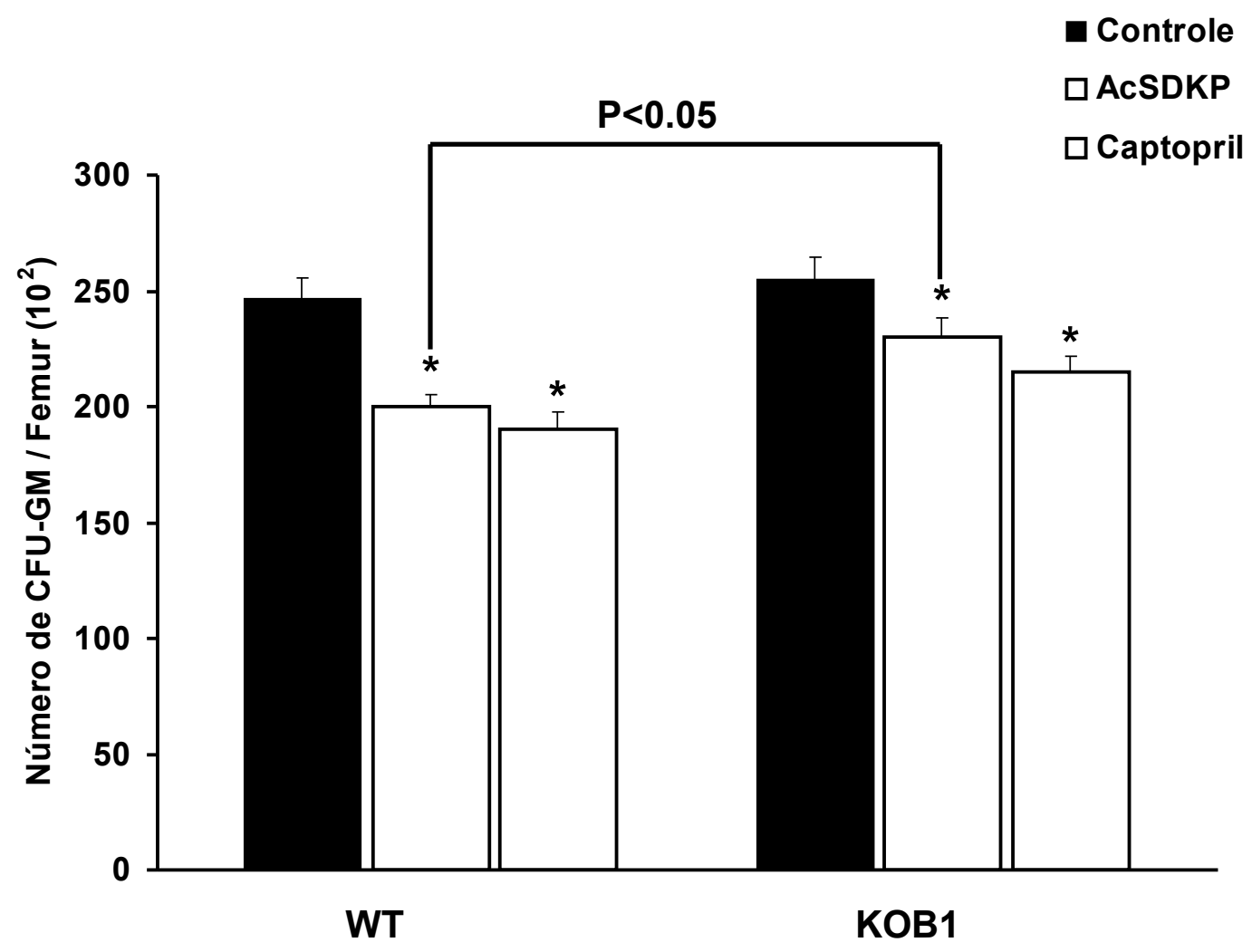

Figura 31 - Efeito dos compostos AcSDKP (10 $\mu \mathrm{g})$ e captopril $(100 \mathrm{mg} / \mathrm{kg})$ na formação de colônias de precursores hematopoéticos para granulócitos e macrófagos (CFUGM) da medula óssea de animais WT e KOB1 submetidos ao tratamento $(n=5)$. $\left({ }^{*}\right)$ Significativo em relação ao controle (salina). P<0.05 - ANOVA; TukeyKramer. 


\section{DISCUSSÃO}

A hematopoese, fenômeno que dá origem a todas as células circulantes, é um sistema orgânico altamente organizado e complexo. As células maduras são derivadas de células-tronco hematopoéticas em uma complexa série de etapas de divisão e maturação. Os fatores que regulam a proliferação, a diferenciação, o comprometimento e a sobrevivência das células hematopoéticas ainda não estão totalmente elucidados. No entanto, sabe-se que a hematopoese é controlada por efeitos combinados de citocinas, fatores de crescimento, receptores celulares de membrana específicos e toda sinalização presente no microambiente medular (HAZNEDAROGLU et al., 1996).

Recentemente, estudos demonstraram que drogas inibidoras da ECA (IECA) são capazes de proteger o microambiente hematopoético dos efeitos tóxicos da radioterapia e quimioterapia, uma vez que, a inibição desta enzima na medula óssea, leva ao aumento da concentração endógena do tetrapeptídeo AcSDKP, um dos reguladores negativos da hematopoese, mantendo as células hematopoéticas mais primitivas em estágio quiescente (CHARRIER et al., 2004). Antes disso, trabalhos como os de Van Brummelen et al. (1980), Cooper (1983) e Casato et al. (1995), demonstraram alterações na hematopoese medular, como agranulocitose, neutropenia e granulocitopenia em pacientes submetidos à terapia em longo prazo com drogas inibidoras da ECA. Seguindo esta linha de raciocínio, Comte et al. (1997) verificaram oscilações na proliferação de células progenitoras CFU-mix, CFUGM e BFU-E em pacientes tratados com enalapril e os trabalhos de Chisi et al. (1999, 2000) demonstrando que a inibição da ECA na medula óssea, diminui o número de células progenitoras para granulócitos e macrófagos e diminui o tempo de recuperação do microambiente medular em animais submetidos a tratamento quimioterápico. Parte destes efeitos hematoprotetores mediados pelas drogas inibidoras da ECA foi atribuída ao aumento endógeno das concentrações de AcSDKP.

A ECA, um elemento em comum do SRA e do SCC, é uma zinco metaloprotease, que converte angiotensina-I em angiotensina-II e inativa a bradicinina (CRISAN e CARR, 2000). A especificidade primária da ECA é remover 
dipeptídeos na posição carboxi terminal de um substrato, embora outras clivagens atípicas tenham sido descritas. A ECA desempenha um papel central na regulação da pressão sanguínea por agir em dois substratos fisiológicos, a angiotensina-I e a bradicinina. No entanto, as funções fisiológicas desta enzima não são limitadas à função cardiovascular, pois como descrito anteriormente, esta enzima parece estar envolvida também na regulação da proliferação de hematopoéticas através da constante degradação do tetrapeptídio AcSDKP (MICHAUD et al., 1999; CHARRIER et al., 2004). Este tetrapeptídio é liberado a partir de sua proteína precursora, a thymosin- $\beta 4$ na medula óssea e é capaz de inibir a entrada das células-tronco hematopiéticas na fase $S$ do ciclo celular, bloqueando a síntese de DNA (RHALEB et al., 2001). A ECA apresenta dois domínios ( $\mathrm{C}$ e N) que apresentam um alto grau de homologia, principalmente nos sítios catalíticos, mas diferem em algumas características. Primeiro, os dois sítios catalíticos são ativados diferentemente pelos íons cloreto e segundo, enquanto ambos os domínios clivam bradicinina, substância $P$ e Angiotensina-I, a taxa de hidrólise difere: por exemplo, a angiotensina-I é convertida três vezes mais rápidas pelo domínio-C (MICHAUD et al., 1999). Interessante, o AcSDKP é hidrolizado 50 vezes mais rápido pelo sítio ativo do domínio-N quando comparado com o domínio-C, constituindo-se, deste modo, em um substrato natural e específico do domínio-N da ECA (ROUSSEAU et al., 1995; AZIZI et al., 2001; JUNOT et al., 2001).

Antes de iniciarmos o estudo do papel da ECA na regulação da resposta hematopoética, avaliamos a presença da enzima em células aderentes e não aderentes obtidas da medula óssea dos animais normais, sem modificações genéticas.

A técnica de Microscopia confocal realizada com células obtidas na cultura de medula óssea de animais WT revelou a presença da ECA nestas células. Outras ferramentas utilizadas neste estudo, como o western blotting e a RT-PCR em tempo real, também resultaram em dados similares.

Em relação à expressão gênica da ECA em animais WT e KOB1, utilizando a técnica de RT-PCR em tempo real e a metodologia de western blotting para analisarmos a expressão protéica, verificamos que os animais KOB1 apresentam uma tendência a uma maior concentração de mRNA para a ECA, assim como maior 
quantidade de proteína, embora este aumento não tenha sido significativo quando comparada aos animais WT. Contudo, ao avaliarmos a atividade catalítica da ECA no tecido medular e nas CLLD de animais nocautes em relação aos animais WT, observamos aumento significativo neste parâmetro. Estes dados a princípio contraditórios, onde verificamos um aumento na atividade catalítica com níveis aparentemente similares aos dos animais normais nas expressões gênica e protéica podem ser explicados, pelo menos em parte, através das possíveis interações existentes entre receptores de cininas e a ECA.

Um exemplo da possível comunicação entre receptores de cininas, em particular, o receptor B2, é dado por Tom et al. (2002). Estes autores, ao utilizarem artérias de porcos concluíram que os inibidores da ECA podem potencializar a bradicinina através de um processo metabólico explicado com bases na colocalização ECA/receptor B2 na membrana de células endoteliais. Além disso, acredita-se que independentemente da redução na hidrólise da bradicinina por parte de inibidores da ECA, o crosstalk entre ECA-receptor B2 seja responsável por efeitos regulatórios positivos e/ou ativação mais eficiente dos sinais de transdução nestes receptores, bem como ativação direta de receptores B1 (TOM et al., 2003). Ainda em relação aos receptores B1, Sabatini et al. (2006), observaram que não houve modificação na atividade da ECA em células $\mathrm{CHO}$ transfectadas com ECA e o receptor B1, sugerindo que a interação seja especifica entre a enzima e o receptor B2 e que provavelmente independa da presença do receptor B1. Baseando-se no fato de que em células endoteliais, o receptor B2 de cinina e ECA estão localizados em sítios muito próximos na membrana celular, provavelmente formando heterodímeros (ERDOS et al., 1999; MARCIC et al., 1999; CHEN et al., 2006), poderíamos sugerir uma modulação por parte do receptor B2 na atividade da catalítica da enzima, embora alguns autores procurem determinar se a distância entre a ECA e os receptores B2 na membrana plasmática possibilite um aumento na atividade destes receptores (CHEN et al., 2006). Em 2000, Marcic et al., discorrendo sobre a re-sensibilização de receptores com base em seus experimentos utilizando análogos de bradicinina resistentes a ECA, sugere que o potencial de resensibilização desses receptores resulta do crosstalk entre a ECA e os receptores B2 na membrana celular. Além disso, Sabatini et al. (2006), ao utilizar células CHO transfectadas que co-expressavam ECA e a região codificadora dos receptores de 
cininas, observaram aumento na atividade da ECA, sugerindo que o receptor B2 possa modular esta atividade. Interessante notar que este efeito foi abolido quando foi adicionado o antagonista específico de receptores B2, HOE-140. Assim sendo, poderíamos sugerir uma possível influência dos receptores B2 sobre a atividade da ECA em nosso estudo, sugerindo a dependência da comunicação destas moléculas na membrana celular. Estes dados também nos permitem concluir que a atividade da ECA em tecido medular não está diretamente relacionada à sua expressão gênica, podendo ser modulada por outros fatores internos e/ou outros mecanismos moduladores de sua atividade como descritos acima.

Com relação aos agonistas de receptores de cininas utilizados no tratamento in vitro, estes não alteraram de modo significativo à atividade catalítica da ECA, pois não observamos alterações significativas nas culturas tratadas em relação ao controle.

Desta forma, diante destes resultados podemos sugerir que o papel das cininas no processo de hematopoese se deve principalmente devido à ação direta destas sobre células já maduras, como leucócitos (MOREAU et al., 2005), ou de acordo com Moore et al. (1990), de alguma forma a bradicinina, juntamente com outras moléculas, produzida no microambiente hematopoético, possa agir como moduladores na produção de novas células de defesa, entre eles os macrófagos.

A atividade catalítica da ECA também foi avaliada nas CLLD tratadas com captopril e AcSDKP, e os resultados apresentados mostraram variações na atividade da enzima. A redução da atividade da ECA nas culturas tratadas com captopril já era esperada, uma vez que este fármaco é altamente específico para a inibição da atividade desta enzima. Vale ressaltar, que no caso dos animais KOB1, a atividade catalítica da ECA se mostrou mais intensa em relação ao grupo WT, indicando a possibilidade destes animais apresentarem alguma modulação da sua atividade no tecido medular, como descrito anteriormente. Diferentemente dos resultados obtidos com captopril, as CLLD de animais KOB1 tratadas com AcSDKP não apresentaram diminuição significativa em relação ao grupo WT, dado este que pode estar relacionado ao aumento na atividade da ECA descrito anteriormente. Para melhor caracterizarmos estes resultados realizamos também a técnica de RT-PCR em tempo real para avaliarmos as possíveis alterações na expressão do mRNA da ECA nas CLLD provenientes de animais KOB1 e WT tratadas com AcSDKP. Os 
resultados mostraram aumento significativo nos níveis de mRNA da ECA nas CLLD de animais WT tratadas com 3nM de AcSDKP e ausência de aumento significativo nos níveis de mRNA nas CLLD de animais KOB1. Uma possível explicação para este padrão de resultado, ainda que parcial, poderia ser dada em função das alças de retro-alimentação, uma vez que a elevação nos níveis de AcSDKP, um substrato natural da ECA (ROUSSEAU et al., 1995; AZIZI et al., 2001; JUNOT et al., 2001), poderia aumentar a expressão gênica desta enzima. Padrões de respostas como as obtidas neste ensaio, foram observados por Harada et al em 2001, quando através da técnica de RT-PCR em tempo real, detectaram um aumento na expressão do mRNA da ECA quando culturas de cardiomiócitos foram submetidas ao tratamento com aldosterona. Neste mesmo sentido, utilizando células endoteliais de aorta de ratos e a técnica de RT-PCR em tempo real, Sugiyama et al., em 2005, observaram aumento dos níveis de mRNA da ECA, quando o mesmo tratamento com aldosterona aumentou os níveis de mRNA desta enzima neste tipo celular. Em relação ao tratamento das CLLD com 5 nM de AcSDKP, observamos que a expressão do mRNA da ECA nestas CLLD foi praticamente suprimida. O estudo de Kanasaki et al. (2003), mostra a capacidade de inibição do AcSDKP sobre a expressao do mRNA de algumas moléuclas de células mesangiais dos rins, como TGF-1-induced plasminogen activator inhibitor-1 e o colágeno alfa-2. Assim sendo, este achado poderia ser explicado pelo fato do AcSDKP, em determinadas concentrações, ter a capacidade de aumetar ou reduzir a expressão dos níveis de mRNA da ECA, apresentando um efeito supra ou infra-regulatório em relação à expressão do mRNA da ECA neste sistema de cultura.

Assim sendo, demos continuidade ao nosso trabalho estudando como a atividade da ECA poderia modular a capacidade proliferativa de células da medula óssea de animais WT e KOB1 utilizando para isto o modelo de CLLD estabelecida por Dexter em 1977. De acordo com as descrições convencionais, este sistema é constituído por uma mistura de células hematopoéticas, macrófagos, células acumuladoras de lipídios, osteoblastos, fibroblastos e células endoteliais. Portanto, utilizando este sistema de cultivo avaliamos o papel do substrato da ECA, o AcSDKP e o efeito do composto inibidor da ECA, o captopril sobre as células das CLLD dos animais envolvidos neste estudo, uma vez que ambos atuam através de 
mecanismos similares. Assim sendo, as suspensões celulares das culturas tratadas com AcSDKP e captopril apresentaram uma redução significativa no número de células não-aderentes provenientes de animais WT e KOB1 durante todo o período de cultivo quando comparadas ao grupo controle (cultura tratadas com salina). Porém, um maior número de células não-aderentes nos animais KOB1 quando comparado aos animais WT foi observado. Quanto ao número de células aderentes, obtidas nas monocamadas após tripsinização, este foi significativamente maior em todos os grupos tratados (WT e KOB1) com AcSDKP e captopril ao compararmos com o grupo controle (salina). No entanto, uma vez mais, observamos nas culturas dos animais KOB1 tratadas com AcSDKP uma redução significativa no número de células aderentes em relação aos animais WT tratados com o mesmo tetrapeptídeo. Este resultado mostrou-se similar ao das culturas tratadas com captopril. Entretanto, estas diferenças não foram significativas quando comparadas aos animais WT. Assim, os dados obtidos com os animais nocautes mais uma vez sugerem que a atividade catalítica aumentada da ECA possa influenciar nos efeitos do AcSDKP sobre a capacidade proliferativa da medula óssea como descrito aqui.

Com relação à proliferação e a diferenciação de progenitores hematopoéticos, observamos que o número de CFU-GM se apresentou reduzido nas culturas oriundas de animais WT e KOB1 quando tratadas com AcSDKP e captopril em relação ao grupo salina. Estas alterações também foram menos pronunciadas nos animais KOB1, corroborando mais uma vez os resultados obtidos até o momento.

O padrão de resposta de drogas IECA e sua correlação com a proteção da medula óssea frente a agentes quimioterápicos e a exposição deste tecido à radiação tem sido observados em vários trabalhos (ROUSSEAU-PLASSE et al., 1996; CHISI et al., 1997; CHISI et al., 1999; CHISI et al., 2000; CAIRES et al., 2004; CHARRIER et al., 2004).

Assim sendo, os resultados descritos anteriormente poderiam ter uma explicação baseada no fato do próprio AcSDKP atuar diretamente sobre progenitores comprometidos com determinada linhagem hematopoética ( $\mathrm{CHISI}$ et al., 1999), impedindo que estas entrem nas fases do ciclo celular e sejam liberadas para o sobrenadante. (MICHAUD et al., 1999; CHARRIER et al., 2004). Dados recentes na literatura demonstram que o AcSDKP é capaz de inibir, por exemplo, a ciclina D1 e 
aumentar a expressão da proteína p53 em células mesangiais dos rins (KANASAKI et al., 2006) modulando assim o ciclo celular. Com relação ao captopril, podemos sugerir que a inibição da ECA por este composto, aumentaria os níveis de AcSDKP no microambiente hematopoético, uma vez que este é um substrato natural da ECA (ROUSSEAU et al., 1995; AZIZI et al., 2001; JUNOT et al., 2001; AKSU et al., 2006; BEYAZIT et al., 2007). Deste modo, o captopril poderia agir indiretamente, através do aumento dos níveis de AcSDKP, que é amplamente preservado na presença de inibidores da ECA (CHISI et al., 1999).

$\mathrm{Na}$ tentativa de melhor caracterizarmos o papel do AcSDKP sobre a proliferação de células hematopoéticas, neste trabalho também quantificamos os níveis de AcSDKP nas culturas tratadas com captopril e nas culturas controle (salina), com o objetivo de correlacionarmos os níveis deste tetrapeptídeo com o número de células que permaneceram aderidas no estroma e aquelas que foram liberadas para o sobrenadante, além de possíveis alterações na proliferação e diferenciação destas células. Os resultados obtidos mostraram níveis basais de AcSDKP nas culturas que receberam salina. Por outro lado, nas culturas tratadas com captopril, os níveis de AcSDKP foram significativamente maior em relação às culturas tratadas com salina, comprovando assim que a inibição da ECA desencadeia em um aumento nos níveis de AcSDKP no microambiente medular, completando assim nossa linha de raciocínio discutido até o momento. Aumento nos níveis deste tetrapeptídeo também foi relatado por Li et al., 1997. Estes autores verificaram aumento nos níveis de AcSDKP em células humanas quando cultivadas em sistemas de culturas líquidas de longa duração, sugerindo assim que este regulador hematopoético seria produzido por células aderentes destas culturas. Outros estudos posteriores também relataram resultados semelhantes (AZIZI et al., 1996; MICHAUD et al., 1997; GAUDRON et al., 1999).

Quando analisamos os níveis de AcSDKP em animais nocautes verificamos que estes foram menores quando comparados às CLLD de animais WT. Estes resultados também podem ser atribuídos, ao menos em parte, ao aumento da atividade catalítica da ECA observado nestes animais e discutido anteriormente. 
Com o objetivo de confirmarmos nossos resultados sobre o papel hematorregulador do AcSDKP e do captopril na proliferação de progenitores hematopoéticos da medula óssea, realizamos também análises através de citometria de fluxo em células cocultivadas sobre a monocamada seguido de tratamento tanto com AcSDKP com o captopril, para observamos a possível ocorrência de alterações no número de progenitores hematopoéticos nos diferentes tratamentos. Os resultados obtidos corroboram os resultados obtidos na literatura com os ensaios que avaliam células formadoras de colônia de alto potencial proliferativo HPP-CFCs (High Proliferative Potential Colony-Forming Cells) (MASSE et al., 1998; CHISI et al., 2000, CHISI et al., 1999; CHISI et al., 2000). As análises de citometria demonstraram que a porcentagem de progenitores em fase $S$ é maior nas culturas tratadas com AcSDKP e captopril em animais WT em relação ao controle (salina). Um maior número de células em fase $S$ também foi observado em animais nocautes. Porém este aumento foi menos significativo em relação aos animais WT.

Realizamos ainda a imunofenotipagem das células das CLLD objetivando observarmos diferenças na distribuição das populações hematopoéticas oriundas das CLLD após tratamento com AcSDKP e captopril.

A imunofenotipagem se limitou à linhagem mielóide, uma vez que no sistema de cultura utilizado neste trabalho, esta é a linhagem predominante. Assim, reduções significativas na população eritróide $\left(T e r 119^{+}\right)$e na população de granulócitos e macrófagos $\left(\mathrm{Gr} 1^{+} / \mathrm{Mac}^{+}\right)$das culturas de animais $\mathrm{KOB} 1$ foram observadas, quando comparadas às culturas de animais WT. Estes dados podem ser atribuídos a maior atividade catalítica da ECA, com conseqüente diminuição nos níveis de AcSDKP o que resultaria então, em maior diferenciação de células na cultura. Neste sentido, o microambiente das CLLD não favorece a permanência por longos períodos de determinadas linhagens, como no caso da linhagem eritróide, reconhecida pelo marcador Ter119 em diferentes estágios, desde pró-eritroblastos até eritrócitos maduros (SPOONCER et al., 2007). Assim, quanto mais rapidamente são diferenciadas, menos tempo estarão presentes no estágio maduro nestes modelos de cultivo. Ao adicionarmos captopril nas CLLD, os resultados indicaram tendência a um aumento desta população, no entanto a diferença não foi significativa. Em relação às células tronco de longa e curta duração podemos aplicar o mesmo 
raciocínio, ou seja, a medida em que o AcSDKP é degradado, mais células tornamse aptas ao processo de diferenciação.

Quanto a imunofenotipagem destas células e identificação da possível população responsável pela expressão da ECA no tecido medular, estes dados são conflitantes na literatura. Segundo Chisi et al. (1999), os macrófagos são os principais responsáveis pela expressão da enzima no tecido medular. No entanto, Strawn et al. (2004) demonstraram que células hematopoéticas de ratos, como por exemplo, as CD45+, são capazes de expressar a ECA, além de demonstrarem esta mesma capacidade em células da população estromal. Assim sendo, com o objetivo de respondermos também a estas questões, realizamos a dupla marcação através de citometria de fluxo em células da medula óssea de animais WT e KOB1. Nossos resultados demonstraram que a população de células estromais, de ambos os animais, são capazes de expressar a ECA, sugerindo assim que a expressão desta enzima esteja restrita à células aderentes neste sistema de cultura e praticamente não é expressa em células hematopoéticas.

Realizamos também, para verificar se os achados in vitro se reproduziam in vivo, um estudo para observamos o efeito hematorregulador do AcSDKP e do captopril por meio da administração destes compostos nos animais WT e KOB1. Utilizando a metodologia de ensaio clonogênico em soft-ágar, quantificamos o número de precursores hematopoéticos capazes de se diferenciar na linhagem granulocítica e macrofágica. Nos animais que foram tratados com o AcSDKP, a redução destes precursores foi significativa. O mesmo se observou nos animais que receberam captopril, que indiretamente, ao inibir esta enzima, elevaria os níveis de AcSDKP na medula, resultando em paralisação desta células na fase $S$ do ciclo celular (RHALEB et al., 2001). No entanto, os animais KOB1, novamente apresentaram resistência ao efeito hematorregulador do AcSDKP, em relação aos animais WT, provavelmente pelo fato desses animais apresentarem maior atividade catalítica da ECA no tecido medular e/ou algum tipo de regulação por parte dos receptores $\mathrm{B} 2$, como já discutido anteriormente.

Desta forma, os resultados obtidos in vivo confirmaram os dados in vitro demonstrando assim o importante papel fisiológico do tetrapeptídeo AcSDKP na 
regulação negativa da hematopoese (MICHAUD et al., 1999; CHARRIER et al., 2004; ), confirmando resultados obtidos em outros trabalhos em que se observa redução significativa destes precursores quando da presença de inibidores da ECA, principalmente o captopril (ROUSSEAU et al., 1995; AZIZI et al., 2001; JUNOT et al., 2001).

Diante dos resultados obtidos, podemos sugerir que os elementos do SCC estudados não participam diretamente do controle da resposta hematopoiética, e sim indiretamente, pois as principais alterações observadas no controle e participação ativa do processo de proliferação de células hematopoéticas estão relacionadas à maior atividade da ECA conseqüente modulação nos níveis de AcSDKP. No entanto, diante das evidências encontradas na literatura e diante dos resultados obtidos neste trabalho, podemos sugerir que de alguma forma, a ausência dos receptores B1 nos animais nocautes, propicie alguma forma de comunicação entre os receptores $\mathrm{B} 2$ e a $\mathrm{ECA}$, que indiretamente, favoreceria a regulação positiva desta enzima. No entanto, estudos futuros se tornam necessários para a elucidação dos mecanismos moleculares envolvidos neste processo.

Quanto aos estudos envolvendo os efeitos do AcSDKP sobre a hematopoese podemos sugerir que a ECA, através de sua atividade catalítica sobre o AcSDKP é capaz de controlar indiretamente o processo de proliferação celular na medula óssea. É interessante observamos que as concentrações de AcSDKP podem controlar a expressão da ECA no tecido medular, deixando claro a participação deste sistema sobre as células hematopoéticas. Além disso, neste trabalho conseguimos elucidar quais são as principais populações medulares envolvidas na expressão da ECA. 


\section{CONCLUSÃO}

Este estudo envolvendo o papel da ECA sobre a resposta hematopoética em animais WT e KOB1 permite concluir que:

1. A ECA está presente, principalmente em células estromais, e participa indiretamente do controle hematopoético através de sua atividade catalítica sobre o AcSDKP.

2. O AcSDKP, quando adicionado às culturas, provoca uma aumento na expressão do mRNA da ECA na concentração de 3ฤM. Já a maior concentração testada, a de $5 \eta M$, reduziu a expressão do mRNA da ECA.

3. Os animais KOB1 apresentam um aumento na atividade catalítica da ECA e uma tendência a maior aumento, porém não significativo, nos níveis de mRNA e na expressão protéica da ECA. Este aumento na atividade da ECA influência a resposta hematopoética destes animais.

4. Animais KOB1 foram mais resistentes ao tratamento in vivo com AcSDKP e captopril nas concentrações utilizadas neste estudo, pois verificamos menor alteração no número de precursores hematopoéticos nestes animais após tratamento, sugerindo assim uma relação com o aumento da atividade catalítica da ECA verificada nestes animais.

5. O aumento da atividade catalítica da ECA em animais KOB1 parece ser independente de sua expressão gênica e protéica.

6. A ativação dos receptores B1 e B2 em animais WT não alterou a expressão gênica e atividade catalítica da ECA no modelo de cultura estudado.

7. A expressão da ECA se dá em células estromais, conforme verificado na análise por citometria de fluxo, sugerindo que a expressão desta enzima não é restrita aos macrófagos como sugere a literatura. 


\section{REFERÊNCIAS BIBLIOGRÁFICAS ${ }^{1}$}

ABALI, H.; HAZNEDAROGLU, I.C.; GOKER, H.; CELIK. I; OZATLI, D.; KORAY, Z. et al. Circulating and local bone marrow renin-angiotensin system in leukemic hematopoiesis: preliminary evidences. Hematology, v.7, n.2, p. 75-82, 2002.

AKSU, S.; BEYAZIT, Y.; HAZNEDAROGLU, I.C.; CANPINAR, H.; KEKILLI, M.; UNER, A.; SAYINALP, N.; BÜYÜKAŞIK, Y.; GOKER, H.; OZCEBE, O.I. Overexpression of angiotensin-converting enzyme (CD 143) on leukemic blasts as a clue for the activated local bone marrow RAS in AML. Leuk. Lymph., v. 47, n. 5, p. 891896, 2006.

ALVES, M.F.; ARAÚJO, M.C.; JULIANO, M.A.; OLIVEIRA, E.M.; KRIEGER, J.E.; CASARINI, D.E.; JULIANO, L.; CARMONA, A.K. A continuous fluorescent assay for the determination of plasma and tissue angiotensin l-converting enzyme activity. Braz. J. Med. Biol. Res., v. 38, n. 6, p. 861-868, 2005.

ALLOGHO, S.N.; GOBEIL, F.; PERRON, S.I. ;HESS, J.F.; REGOLI, D. Effects of kinins on isolated Stomachs of control and transgenic knockout B2 receptor mice. Naunyn-Schmiedeberg`s Arch. Pharmacol., v.357, p. 191-196, 1998.

ARAÚJO, R. C.; KETTRITZ, R.; FICHTNER, I.; PAIVA, A. C. M.; PESQUERO, J. B.; BADER, M. Alttered neutropil homeostase in kinin B1 receptor-deficient mice. Biol. Chem., v. 382, n. 1, p. 91-95. 2001.

ARAUJO, M.C.; MELO, R.L.; CESARI, M.H.; JULIANO, M.A.; JULIANO, L.; CARMONA, A.K. Peptidase specificity characterization of $\mathrm{C}$ - and $\mathrm{N}$-terminal catalytic sites of angiotensin I-converting enzyme. Biochemistry, v. 39, n. 29, p. 8519-8525, 2000.

AUCH-SCHWELK, W.; BOSSALLER, C.; CLAUS, M.; GRAF, K.; GRÄFE, M.; FLECK, E. Local potentiation of bradykinin-induced vasodilation by convertingenzyme inhibition in isolated coronary arteries. J. Cardiovasc. Pharmacol., v. 20, Suppl. 9, p. S62-67, 1992.

AZIZI, M.; JUNOT, C.; EZAN, E.; MENARD, J. Angiotensin I-converting enzyme and metabolism of the haematological peptide $\mathrm{N}$-acetyl-seryl-aspartyl-lysyl-proline. Clin. Exp. Pharmacol. Physiol., v. 28, n. 12. p. 1066-1069, 2001.

AZIZI, M.; MASSIEN, C.; MICHAUD, A.; CORVOL, P. In vitro and in vivo inhibition of the 2 active sites of ACE by omapatrilat, a vasopeptidase inhibitor. Hypertension., v. 35, n. 6 , p. 1226-1231, 2000.

\footnotetext{
${ }^{1}$ De acordo com: ASSOCIAÇÃO BRASILEIRA DE NORMAS TÉCNICAS. NBR 6023: Informação e documentação: referências: elaboração. Rio de Janeiro, 2002.
} 
AZIZI, M.; ROUSSEAU, A.; EZAN, E.; GUYENE, T.; MICHELET, S.; GROGNET, J. et al. Acute angiotensi-converting enzyme inhibition increases the plasma level of the natural stem cell regulator N-Acetyl-Seryl-Aspartyl-Lysyl-Proline. J. Clin. Invest., v. 97, n. 3, p. 839-844, 1996.

BANEGAS, I.; PRIETO, I.; VIVES, F.; ALBA. F.; DE GASPARO, M.; SEGARRA, A.B.; HERMOSO, F.; DURÁN, R.; RAMÍREZ, M. Brain aminopeptidases and hypertension. J. Renin Angiotensin Aldosterone Syst, v. 7, n. 3, p. 129-134, 2006.

BENTLEY, S.A.; FOIDART, J.M.; KLEINMAN, H.K. Connective tissue elements in rat bone marrow: immunofluorescent visualization of the hematopoietic microenvironment. J. Histochem. Cytochem., v. 32, n. 1, p. 114-116, 1984.

BENTLEY, S.A.; TRALKA, T.S. Fibronectin-mediated attachment of hematopoietic cells to stromal elements in continuous bone marrow culture. Exp. Hematol., v. 11, n. 2, p. 129-138, 1983.

BEYAZIT, Y.; AKSU, S.; HAZNEDAROGLU, I.C.; KEKILLI, M.; MISIRLIOGLU, M.; TUNCER, S.; KARAKAYA, J.; KOCA, E.; BUYUKASIK, Y.; SAYINALP, N.; GOKER, $\mathrm{H}$. Overexpression of the local bone marrow renin-angiotensin system in acute myeloid leukemia. Natl. Med. Assoc., v. 99, n. 1, p.57-63, 2007.

BHOOLA, K.D.; FIGUEROA, C.D.; WORTHY. K. Bioregulation of kinins: kallikreins, kininogens, and kininases. Pharmacol. Rev., v. 44, n.1, p. 1-80, 1992.

BIANCO, P.; RIMINUCCI, M.; GRONTHOS, S.; ROBEY, P.G. Bone marrow stromal stem cells: nature, biology, and potential applications. Stem Cells, v. 19, n. 3, p. 180192, 2001.

BOGDEN, A.E.; CARDE, P.; DE PAILLETTE, E.D.; MOREAU, J.P.; TUBIANA, M.; FRINDEL, E. Amelioration of chemotherapy-induced toxicity by cotreatment with AcSDKP, a tetrapeptide inhibitor of hematopoietic stem cell proliferation. Ann. N. Y. Acad. Sci., v. 628, p. 126-139, 1991.

BONNET, D.; CESAIRE, R.; LEMOINE, F.; AOUDJHANE, M.; NAJMAN, A.; GUIGON, M. The tetrapeptide AcSDKP, an inhibitor of the cell-cycle status for normal human haematopoietic progenitors, has no effect on leukemic cells. Exp. Hematol., v. 20 , n. 2, p. 251-255, 1992.

BRADFORD, M. M. A rapid and sensitive method for the quantitation of microgram quantities of protein utilizing the principle of protein-dye binding. Anal. Biochem., v. 72, p. 248-254, 1976.

BRADLEY, T.R.; METCALF, D. The growth of mouse bone marrow cells in vitro. Aust. J. Exp. Biol. Med. Sci., v. 44, n. 3, 287-299, 1966.

BURCH, R.M.; FARMER, S.G.; STERANKA, L,R. Bradykinin receptor antagonists. Med. Res. Rev., v. 10, n. 2, p. 237-269, 1990, Review. 
CAIRES, A.C.; OLIVEIRA, C.R.; SMITH, M.C.; HEMERLY, J.P.; JULIANO, M.A.; BINCOLETTO, C. Effects of palladacycle complex on hematopoietic progenitor cells proliferation in vivo and in vitro and its relation with the inhibitory properties of this compound on the angiotensin-I converting enzyme activity. Immunopharmacol. Immunotoxicol., v. 26, n. 4, p. 487-500, 2004.

CASATO, M.; PUCILLO, L.P.; LEONI, M.; DI LULLO, L.; GABRIELLI, A.; SANSONNO, D.; DAMMACCO, F.; DANIELI. G.; BONOMO, L. Granulocytopenia after combined therapy with interferon and angiotensin-converting enzyme inhibitors: evidence for a synergistic hematologic toxicity. Am. J. Med., v. 99, n. 4, p.386-391, 1995.

CASHMAN, J.D.; EAVES, A.C.; EAVES, C.J. The tetrapeptide AcSDKP specifically blocks the cycling of primitive normal but not leukemic progenitors in long term culture:evidence for an indirect mechanism. Blood, v. 84, n. 5, p. 1534-1542, 1994.

CAVASIN, M.A.; RHALEB, N.E.; YANG, X.P.; CARRETERO, O.A. Prolyl oligopeptidase is involved in release of the antifibrotic peptide Ac-SDKP. Hypertension, v. 43, n. 5, p. 1140-1145, 2004.

CHARRIER, S.; MICHAUD, A.; BADAOUI, S.; GIROUX, S.; EZAN, E.; SAINTENY, F.; CORVOL, P.; VAINCHENKER, W. Inhibition of angiotensin I-converting enzyme induces radioprotection by preserving murine hematopoietic short-term reconstituting cells. Blood, v. 104, n. 4, p. 978-985, 2004.

CHEN, Z.; DEDDISH, P.A.; MINSHALL, R.D.; BECKER, R.P.; ERDOS, E.G.; TAN, F. Human ACE and bradykinin $B 2$ receptors form a complex at the plasma membrane. FASEB. J., v. 20, n. 13, p. 2261-2270, 2006.

CHISI, J.E.; BRISCOE, C.V.; EZAN, E.; GENET, R.; RICHES, A.C.; WDZIECZAKBAKALA, J. Captopril inhibits in vitro and in vivo the proliferation of primitive haematopoietic cells induced into cell cycle by cytotoxic drug administration or irradiation but has no effect on myeloid leukaemia cell proliferation. Br. J. Haematol., v. 109, n. 3, p. 563-570, 2000.

CHISI, J.E.; WDZIECZAK-BAKALA, J.; THIERRY, J.; BRISCOE, C.V.; RICHES, A.C. Captopril inhibits the proliferation of hematopoietic stem and progenitor cells in murine long-term bone marrow cultures. Stem Cells, v.17, p. 339-44, 1999.

CHISI, J.E.; WDZIECZAK-BAKALA, J.; RICHES, A.C. Inhibitory Action of the Peptide AcSDKP on the Proliferative State of Hematopoietic Stem Cells in the Presence of Captopril but not Lisinopril Stem cells, v. 15, p. 455-460, 1997.

COMTE, L.; LORGEOT, V.; VOLKOV, L.; ALLEGRAUD, J.; ALDIGIER, C.; PRALORAN, V. Effects of the angiotensin-converting enzyme inhibitor enalapril on blood haematopoietic progenitors and Acetyl-N-Ser-Asp-Lys-Pro concentrations. Eur. J. Clin. Invest., v. 27, p.788-790, 1997.

COMTE, L.; LORGEOT, V.; BIGNON, J.; VOLKOV, L.; DUPUIS, F.; WDZIECZAK- 
BAKALA, J. et al. In vivo modifications of AcSDKP metabolism and haematopoiesis in mice treated with 5-fluorouracil and Goralatide. Eur. J. Clin. Invest., v. 28, p.856-63, 1998.

COOPER, R.A. Captopril associated neutropenia. Who is at risk? Arch. Intern. Med., v. 143, p.659-660, 1983.

COULOMBEL, L.; AUFFRAY, I.; GAUGLER, M.H.; ROSEMBLATT, M. Expression and function of integrins on hematopoietic progenitor cells. Acta Haematol., v. 97, n. 1-2, p. 13-21, 1997, Review.

CRISAN, D.; CARR, J. Angiotensin I-converting enzyme: genotype and disease associations. J. Mol. Diagn., v. 2, n. 3, p.105-15, 2000. Review.

DAN-ZHAO, W.; JIAN-XING, Ma; CHAO, L.; CHAO, J. Molecular cloning and sequence analysis of rat bradykinin B2 receptor gene. Bioch. Biophys. Act., v. 1219, p. 171-174, 1994.

DELDAR, A. Drug-induced blood disorders: Review of pathogenic mecanisms and utilisation of bone marrow cell culture technology as an investigative approach. Current. Top. Vet. Res., v.1, p. 83-101, 1994.

DELDAR, A.; HOUSE R.V.; WIERDA, D. Bone Marrow colony-forming assays. Methods Immunotoxicol., v.1, p. 227-250, 1995.

DELDAR, A.; STEVENS, C.E. Development and application of in vitro models of hematopoiesis to drug development. Toxicol. Pathol., v. 21, p. 231-40. 1993.

DENNIS, J.E.; CHARBORD, P. Origin and differentiation of human and murine stroma. Stem Cells, v. 20, p. 205, 2002.

DEXTER, T.M.; ALLEN, T.D.; LAJTHA, L.G. Conditions controlling the proliferation of haemopoietic stem cells in vitro. J. Cell. Physiol., v. 91, p. 335-44, 1977.

DEXTER, T.M.; Haemopoiesis in long-term bone marrow cultures. A review. Acta Haematol., v. 62, p. 299-305,1979. Review.

DORSHKIND, K. Regulation of hemopoieisis by bone marrow stromal cells and their products. Annu. Rev. Immunol, v. 8, p. 111-37, 1990.

DRAY, A., PERKINS, M. Bradykinin and inflammatory pain. Trends Neurosci., v. 16, p. 99-104, 1993. Review.

DRZENIEK, Z.; SIEBERTZ, B.; STOCKER, G.; JUST, U.; OSTERTAG, W.; GREILING, $\mathrm{H}$. et al. Proteoglycan synthesis in haematopoietic cells: isolation and characterization of heparan sulphate proteoglycans expressed by the bone-marrow stromal cell line MS-5. Biochem. J., v. 327, p. 473-80, 1997. 
DUBREUIL, P.; FULCRAND, P.; RODRIGUEZ, M.; FULCRAND, H.; LAUR, J.; MARTINEZ, J. Novel activity of angiotensin-converting enzyme. Hydrolysis of cholecystokinin and gastrin analogues with release of the amidated C-terminal dipeptide. Biochem. J., v. 262, n. 1, p. 125-130, 1989.

EAVES, C.J.; CASHMAN, J.D.; KAY, R.J.; DOUGHERTY, G.J.; OTSUKA, T.; GABOURY, L.A. Mechanisms that regulate the cell cycle status of very primitive hematopoietic cells in long-term human marrow cultures. II. Analysis of positive and negative regulators produced by stromal cells within the adherent layer. Blood, v. 78, p. 110-117, 1991.

EGAMI, K.; MUROHARA, T.; SHIMADA, T.; SASAKI, K.; SHINTANI, S.; SUGAYA, T.; ISHII, M.; AKAGI, T.; IKEDA, H.; MATSUISHI, T.; IMAIZUMI, T. Role of host angiotensin II type 1 receptor in tumor angiogenesis and growth. J. Clin. Invest., v. 112, n. 1, p. 67-75, 2003.

EMANUELI, C.; SALIS, M. B.; STACCA, T.; PINNA, A.; GASPA, L; MADDEDDU, P. Angiotensin AT1 receptor signalling modulates reparative angiogenesis induced by limb ischaemia. Britsh. J. Pharmacol., v. 135, n. 87, p. 92, 2002.

ERDOS, E.G. Angiotensin I converting enzyme and the changes in our concepts through the years. Lewis K. Dahl memorial lecture. Hypertension, v. 16, p. 363-70. Review, 1990.

ERDOS, E.G.; DEDDISH, P.A.; MARCIC, B.M. Potentiation of Bradykinin Actions by ACE Inhibitors. Trends Endocrinol. Metab., v. 10, n. 6, p. 223-229, 1999.

FATHY, D.B.; LEEB, T.; MATHIS, S.A.; LEEB-LUNDBERG, L.M. Spontaneous human B2 bradykinin receptor activity determines the action of partial agonists as agonists or inverse agonists. Effect of basal desensitization. J. Biol. Chem., v. 274, n. 42, p. 29603-29606, 1999.

FAUSSNER, A.; BATHON, J.M.; PROUD, D. Comparison of the responses of B1 and B2 kinin receptors to agonist stimulation. Immunopharmacology, v. 45, n. 1-3, p. 13-20, 1999.

FIBBE, W.E.; VAN DAMME, J.; BILLIAU, A.; GOSELINK, H.M.; VOOGT, P.J.; VAN EEDEN, G. et al. Interleukin 1 induces human marrow stromal cells in long-term culture to produce granulocyte colony-stimulating factor and macrophage colonystimulating factor. Blood, v. 71, p. 430-5, 1988.

FRIEDLAND, J.; SILVERSTEIN, E. A sensitive fluorimetric assay for serum angiotensin-converting enzyme. Am. J. Clin. Pathol., v. 66, n. 2, p. 416-24, 1976.

GALLAGHER, J.T.; LYON, M.; STEWARD, W.P. Structure and function of heparan sulphate proteoglycans. Biochem. J., v. 236, p. 313-25,1986. Review.

GAUDRON, S.; GRILLON, C.; THIERRY, J.; RICHES, A.; WIERENGA P.K.; WDZIECZAK-BAKALA, J. "In vitro" Effect of Acetyl-N-Ser-Asp-Lys- Pro (AcSDKP) 
Analogs Resistant to Angiotensin I-Converting Enzyme on Hematopoietic Stem Cell and Progenitor Cell Proliferation. Stem Cells, v. 17, p. 100-06, 1999.

GÖSELE, C.; GRÜTZNER, F.; PESQUERO, J.B.; SILVA, J.A. JR.; JUNGE, T.; GANTEN, D.; BADER, M.; KNOBLAUCH, M.. Assignment of the kinin receptor B1 and $\mathrm{B} 2$ genes (Bdkrb1 and Bdkrb2) to rat chromosome 6q3.2 by FISH and radiation hybrid mapping. Cytogenet Cell Genet., v. 89, n. 1-2, p. 51-52, 2000.

GRILLON, C.; RIEGER, K.; WDZIECZAK-BAKALA, J.; SCHOTT, D.; MORGAT, J.L.; HANNAPPEL, E.; VOELTER, W.; LENFANT, M. Involvementof thymosin $\beta 4$ and endoproteinase Asp- $\mathrm{N}$ in the biosynthesis of the tetrapeptide Acetyl-N-Ser-Asp-LysPro a regulator of the hematopoietic system. FEBS Letters, v. 274, p. 30-34, 1990.

GROIZAT, H. et al. Abscopal effect of irradiation on haemopoietic stem cells of shielded bone marrow. Role of irradiation. J. Radiat. Biol., v. 30, p. 347, 1976.

GU, Y.; SOROKIN, L.; DURBEEJ, M.; HJALT,T.; JONSSON, J.I.; EKBLOM, M. Characterization of bone marrow laminins and identification of alpha5-containing laminins as adhesive proteins for multipotent hematopoietic FDCP-Mix cells. Blood, v. 93, p. 2533-2542, 1999.

GUEST, I.; UETRECHT, J. Bone marrow stem cell protection from chemotherapy by low--molecular-weight compounds. Exp Hemato., v. 29, p. 123-137, 2001. Review.

GUPTA, P.; OEGEMA, T.R. JR.; BRAZIL, J.J.; DUDEK, A.Z.; SLUNGAARD, A.; VERFAILLIE, C,M. Structurally specific heparan sulfates support primitive human hematopoiesis by formation of a multimolecular stem cell niche. Blood, v. 92, n. 12, p. 4641-4651, 1998.

HALL, J.M. Bradykinin receptors: pharmacological properties and biological roles. Pharmacol. Ther., v. 56, p. 131-190. Review, 1992

HARADA, E.; YOSHIMURA, M.; YASUE, H.; NAKAGAWA, O.; NAKAGAWA, M.; HARADA, M.; et al. Aldosterone induces angiotensin-converting-enzyme gene expression in cultured neonatal rat cardiocytes. Circulation, v. 104, n. 2, p. 137-139, 2001.

HAYAKARI, M.; SATOH, K.; OOKAWA, K.; KANO, H.; MURAKAMI, S.; IKEDA, N.; TSUCHIDA, S. Kinetic evaluation of beta-neoendorphin hydrolysis by the somatic and testicular isozymes of human angiotensin-converting enzyme. Biochim. Biophys. Acta., v. 1339, n. 1, p. 31-38, 1997.

HAZNEDAROGLU, I.C. Haematopoietic effects of ACE inhibitors and local bone marrow renin-angiotensin system: An hypothesis. Nephrol Dial Transplant, v. 11, p. 2373, 1996.

HAZNEDAROGLU I.C.; OZTURK,M.A. Towards the understanding of the local hematopoietic bone marrow renin-angiotensin system. Int. J. Biochem. Cell. Biol., v. 35, p. 867-880, 2003. Review. 
HERMAN, P.; FERRANT, A.; DE BRUYERE, M.; STRAETMANS, N. Stromal factors support the expansion of the whole hemopoietic spectrum from bone marrow CD34+DR- cells and of some hemopoietic subsets from CD34+ and CD34+DR+ cells. Leukemia, v. 12, p. 735-745, 1998.

HECKER, M.; PÖRSTI, I.; BUSSE, R. Mechanisms involved in the angiotensin IIindependent hypotensive action of ACE inhibitors. Braz. J. Med. Biol. Res., v. 27, n. 8, p. 1917-1921, 1994.

HIDALGO, A.; SANZ-RODRÍGUEZ, F.; RODRÍGUEZ-FERNÁNDEZ, J.L.; ALBELLA, B.; BLAYA, C.; WRIGHT, N.; CABAÑAS, C.; PRÓSPER, F.; GUTIERREZ-RAMOS, J.C.; TEIXIDÓ, J. Chemokine stromal cell-derived factor-1alpha modulates VLA-4 integrin-dependent adhesion to fibronectin and VCAM-1 on bone marrow hematopoietic progenitor cells. Exp. Hematol., v. 29, n. 3, p. 345-355, 2001.

HUBERT C, SAVARY K, GASC JM, CORVOL P. The hematopoietic system: a new niche for the renin-angiotensin system. Nat. Clin. Pract. Cardiovasc. Med., v. 3, n. 2, p. $80-85.2006$

HUSS, R. Perspectives on the morphology and biology of CD34-negative stem cells. J. Hematother. Stem Cell Res., v. 9, n. 6, p. 783-793, 2000

HUYGEN, S.; GIET, O.; ARTISIEN, V.; DI STEFANO, I.; BEGUIN, Y.; GOTHOT, A. Adhesion of synchronized human hematopoietic progenitor cells to fibronectin and vascular cell adhesion molecule-1 fluctuates reversibly during cell cycle transit in ex vivo culture. Blood, v. 100, p. 2744-2752, 2002.

ICHIKAWA, Y.; PLUZNIK, D.H.; SACHS, L. In vitro control of the development of macrophage and granulocyte colonies. Proc. Natl. Acad. Sci. U.S.A., v.56, p.488495, 1966.

IGNJATOVIC, T.; TAN, F.; BROVKOVYCH, V.; SKIDGEL, R.A.; ERDOS, E.G. Activation of bradykinin B1 receptor by ACE inhibitors. Int. Immunopharmacol., V. 2, n.13-14, p.1787-93. Review, 2002.

ISRAELI, A., OR ,R., LEITERSDORF, E. Captopril-associated transient aplastic anemia. Acta Haematol., v.73, p.106-107, 1985.

IWAMOTO, N.; XANO, H.J.; YOSHIOKA, T.; SHIRAGA, H.; NITTA, K.; MURAKI, T. et al. Acetyl-seryl-aspartyl-lysyl-proline is a novel natural cell cycle regulator of renal cells. Life Sci., v. 66, p. PL221-6, 2000.

JACKSON, J.D.; OZEROL, E.; YAN, Y.; EWEL, C.; TALMADGE, J.E. Activity of acetyl-Ser-Asp-Lys-Pro (AcSDKP) on human hematopoietic progenitor cells in shortterm and long-term bone marrow cultures. J. Hematother. Stem Cell Res., v.9, p. 489-496, 2000.

JUNOT, C.; NICOLET, L.; EZAN, E.; GONZALES, M.F.; MENARD, J.; AZIZ, M. Effect 
of angiotensin-converting enzyme inhibition on plasma, urine, and tissue concentrations of hemoregulatory peptide acetyl-ser-asp-lys-pro in rats. J Pharmacol Exp. Ther., v. 291, p. 982-87, 1999.

JUNOT, C.; PRUVOST, A.; CREMINON, C.; GROGNET, J.M.; BENECH, H.; EZAN, E. Characterization of immunoreactive acetyl-Ser-Asp-Lys-Pro in human plasma and urine by liquid chromatography-electrospray mass spectrometry. J Chromatogr B Biomed. Sci. Appl., v. 752, p. 69-75, 2001.

JUNOT, C.; THEODORO, F.; THIERRY, J.; CLEMENT, G.; WDZIECZAK-BAKALA, J.; EZAN, E. Development of an enzyme immunoassay for a stable amidated analog of the hemoregulatory peptide acetyl-Ser-Asp-Lys-Pro. J. Immunoassay Immunochem., v. 22, p. 15-31, 2001.

JUNOT, C.; GONZALES, M.F.; EZAN, E.; COTTON, J.; VAZEUX, G.; MICHAUD, A.; AZIZI, M.; VASSILIOU, S.; YIOTAKIS, A.; CORVOL, P.; DIVE, V. RXP 407, a selective inhibitor of the $\mathrm{N}$-domain of angiotensin l-converting enzyme, blocks in vivo the degradation of hemoregulatory peptide acetyl-Ser-Asp-Lys-Pro with no effect on angiotensin I hydrolysis. J. Pharmacol. Exp. Ther., v. 297, n. 2, p. 606-11, 2001.

JUSTO, G.Z.; SILVA, M.R.; QUEIROZ, M.L.S. Effects of the green algae chlorella vulgaris on the response of the host hematopoietic system to intraperitoneal ehrlich ascites tumor transplantation in mice. Immunopharmacol. Immunotoxicol., v. 23, p. 119-32, 2001.

KANG, D.S.; GUSTAFSSON, C.; MÖRGELIN, M.; LEEB-LUNDBERG, L.M. B1 bradykinin receptor homo-oligomers in receptor cell surface expression and signaling: effects of receptor fragments. Mol. Pharmacol., v. 67, n. 1, p. 309-318, 2005.

KANASAKI, K.; KOYA, D.; SUGIMOTO, T.; ISONO, M.; KASHIWAGI, A.; HANEDA, M. N-Acetyl-seryl-aspartyl-lysyl-proline inhibits TGF-beta-mediated plasminogen activator inhibitor-1 expression via inhibition of Smad pathway in human mesangial cells. J. Am. Soc. Nephrol., v. 14, n. 4, p. 863-72, 2003.

KANASAKI, K.; HANEDA, M.; SUGIMOTO, T.; SHIBUYA, K.; ISONO, M.; ISSHIKI, K.; ARAKI, S.; UZU, T.; KASHIWAGI, A.; KOYA, D.; N-acetyl-seryl-aspartyl-lysylproline inhibits DNA synthesis in human mesangial cells via up-regulation of cell cycle modulators. Biochem. Biophys. Res. Commun., v. 342, n. 3, p. 758-65, 2006.

KINASHI, T.; SPRINGER, T.A. Adhesion molecules in hematopoietic cells. Blood Cells, v. 20, p. 25-44, 1994.

KINCADE, P.W. Cell interaction molecules and cytokines which participate in B lymphopoiesis. Baillieres Clin. Haematol., v.5, p.575-598, 1992.

KINTSURASHVILI, E.; DUKA, I.; GAVRAS, I.; JOHNS, C.; FARMAKIOTIS, D.; GAVRAS, $H$. Effects of ANG II on bradykinin receptor gene expression in 
cardiomyocytes and vascular smooth muscle cells. Am. J. Physiol. Heart. Circ. Physiol., v. 281, n. 4, p.1778-1783, 2001.

LEEB-LUNDBERG, L.M.; KANG, D.S.; LAMB, M.E.; FATHY, D.B. The human B1 bradykinin receptor exhibits high ligand-independent, constitutive activity. Roles of residues in the fourth intracellular and third transmembrane domains. J. Biol. Chem., v. 276 , n. 12 , p. $8785-8792,2001$.

LEEB-LUNDBERG, L.M.; MARCEAU, F.; MÜLLER-ESTERL, W.; PETTIBONE, D.J.; ZURAW, B.L. International union of pharmacology. XLV. Classification of the kinin receptor family: from molecular mechanisms to pathophysiological consequences. Pharmacol. Rev., v. 57, n. 1, p. 27-77, 2005, Review.

LENFANT, M.; WDZIECZAK-BAKALA, J.; GUITTET, E.; PROME, J.C.; SOTTY, D. FRINDEL, E. Inhibitor of hematopoietic pluripotent stem cell proliferation: purification and determination of its structure. Proc. Natl. Acad. Sci. U.S.A., v. 86, n. 3, p. 77982, 1989.

LI, J.; VOLKOV, L.; COMTE, L.; HERVÉ, P.; PRALORAN, V.; CHARBORD, P. Production and consumption of the tetrapeptide AcSDKP, a negative regulator of hematopoietic stem cells, by hematopoietic microenvironmental cells. Exp. Hematol., v. 25, p. 140-146, 1997.

LIU, J.M.; LAWRENCE, F.; KOVACEVIC, M.; BIGNON, J.; PAPADIMITRIOU, E.; LALLEMAND, J.Y.; KATSORIS, P.; POTIER, P.; FROMES, Y.; WDZIECZAK-BAKALA, $\mathrm{J}$. The tetrapeptide AcSDKP, an inhibitor of primitive hematopoietic cell proliferation, induces angiogenesis in vitro and in vivo. Blood, v. 101, n. 8, p. 3014-20, 2003.

MACEACHERN, A.E.; SHELTON, E.R.; BHAKTA, S.; OBERNOLTE, R.; BACH, C.; ZUPPAN, P.; et al. Expression cloning of a rat B2 bradykinin receptor. Proc. Natl. Acad. Sci. USA, v.88, n.17, p.7724-8, 1991.

MACNEIL, T.; BIERILO, K.K.; MENKE, J.G.; HESS, J.F. Cloning and pharmacological characterization of a rabbit bradykinin B1 receptor. Biochim. Biophys. Acta, v. 1264, n. 2, p. 223-228, 1995

MARCEAU, F. Kinin B1receptors: a review. Immunopharmacology, v. 30, n. 1, p. 126, 1995

MARCIC, B.; DEDDISH, P.A.; JACKMAN, H.L.; ERDÖS, E.G. Enhancement of bradykinin and resensitization of its $B 2$ receptor. Hypertension, v. 33, n. 3, p. 835843, 1999.

MARCIC. B.; DEDDISH, P.A.; JACKMAN, H.L.; ERDÖS, E.G.; TAN, F. Effects of the $\mathrm{N}$-terminal sequence of ACE on the properties of its C-domain. Hypertension, v. 36, n. 1, p. 116-121, 2000.

MASSÉ, A.; RAMIREZ, L.H.; BINDOULA, G.; GRILLON, C.; WDZIECZAKBAKALA, J.; RADDASSI, K. et al. The tetrapeptide Acetyl-N-Ser-Asp-Lys-Pro 
(Goralatide) protects from doxorubicin-induced toxicity: Improvement in mice survival and protection of bone marrow stem cells and progenitors. Blood, v. 91, p. 441-449, 1998.

MATHIS, S.A.; CRISCIMAGNA, N.L.; LEEB-LUNDBERG, L.M. B1 and B2 kinin receptors mediate distinct patterns of intracellular $\mathrm{Ca} 2+$ signaling in single cultured vascular smooth muscle cells. Mol. Pharmacol., v. 50, n. 1, p. 128-139, 1996.

MCNIECE, I.; BRIDELL, R. Ex vivo expansion of hematopoietic progenitor cells and mature cells. Exp. Hematol., v. 29, p. 3, 2001.

MENKE, J.G.; BORKOWSKI, J.A.; BIERILO, K.K.; MACNEIL, T.; DERRICK, A.W.; SCHNECK, K.A.; RANSOM, R.W.; STRADER, C.D.; LINEMEYER, D.L.; HESS, J.F. Expression cloning of a human B1 bradykinin receptor. J. Biol. Chem., v. 269, n. 34, p. 21583-21586, 1994.

MICHAUD, A.; WILLIAMS, T.A.; CHAUVET, M.T.; CORVOL, P. Substrate dependence of angiotensin I-converting enzyme inhibition: captopril displays a partial selectivity for inhibition of $\mathrm{N}$-acetyl-seryl-aspartyl-lysyl-proline hydrolysis compared with that of angiotensin I. Mol. Pharmacol., v. 51, n. 6, p. 1070-1076, 1997

MICHAUD, A.; CHAUVET, M.T.; CORVOL, P. N-domain selectivity of angiotensin Iconverting enzyme as assessed by structure-function studies of its highly selective substrate, N-acetyl-seryl-aspartyl-lysyl-proline. Biochem. Pharmacol., v. 57, n. 6, p. 611-618, 1999.

MINSHALL, R.D.; TAN, F.; NAKAMURA, F.; RABITO, S.F.; BECKER, R.P.; MARCIC, B.; ERDÖS, E.G. Potentiation of the actions of bradykinin by angiotensin l-converting enzyme inhibitors. The role of expressed human bradykinin B2 receptors and angiotensin I-converting enzyme in $\mathrm{CHO}$ cells. Circ. Res., v. 81 , n. 5, p. 848-856, 1997.

MINSHALL, R.D.; ERDÖS, E.G.; VOGEL, S.M. Angiotensin I-converting enzyme inhibitors potentiate bradykinin's inotropic effects independently of blocking its inactivation. Am. J. Cardiol., v. 80, n. 3A, p. 132A-136A, 1997.

MIYAKE, K.; MEDINA, K.; ISHIHARA, K.; KIMOTO, M.; AUERBACH, R.; KINCADE, P.W. A VCAM-like adhesion molecule on murine bone marrow stromal cells mediates binding of lymphocyte precursors in culture. J. Cell Biol., v. 114, p. 557-565, 1991.

MOORE, R.N.; DUMA, E.M.; BOWERSOCK, T.L. Bradykinin sensitization of colonystimulating factor-1-responsive murine marrow progenitors to prostaglandin E. A property of the amino-terminal tetrapeptide fragment. J. Immunol., v. 144, n. 2, p. 667-670, 1990.

MOREAU, M.E.; GARBACKI, N.; MOLINARO, G.; BROWN, N.J.; MARCEAU, F.; ADAM, A. The Kallikrein-Kinin System: Current and Future Pharmacological Targets. J. Pharmacol. Sci., v. 99, p. 6-38, 2005. 
MRUG, M.; STOPKA, T.; JULIAN, B.A.; PRCHAL., J.F.; PRCHAL., J.T. Angiotensin II stimulates proliferation of normal early erythroid progenitors. J. Clin. Invest., v. 100, n. 9, p. 2310-2314, 1997.

NAIDOO, Y.; SNYMAN, C.; RAIDOO, D.M.; BHOOLA, K.D.; KEMME, M.; MÜLLERESTERL, W. Cellular visualization of tissue prokallikrein in human neutrophils and myelocytes. Br. J. Haematol., v. 105, n. 3, p. 599-612, 1999.

OGAWA, M. Differentiation and proliferation of hematopoietic stem cells. Blood., v. 81, n. 11, p. 2844-53. Review, 1993.

OLIVERIO, M.I.; COFFMAN, T.M. Angiotensin II Receptor Physiology Using Gene Targeting. News Physiol. Sci., v. 15, p. 171-175, 2000.

PARCHMENT, R.E.; HUANG, M., ERICKSON-MILLER, C.L. Roles for in vitro myelotoxicity tests in preclinical drug development and clinical trial planning. Toxicol. Pathol., v. 21, n. 2, p. 241-250, 1993.

PESQUERO, J.B.; LINDSEY, C.J.; ZEH, K.; PAIVA, A.C.; GANTEN, D.; BADER, M. Molecular structure and expression of rat bradykinin B2 receptor gene. Evidence for alternative splicing. J. Biol. Chem., v. 269, p. 26920-26925, 1994.

PESQUERO, J.B.; PESQUERO, J.L.; OLIVEIRA, S.M.; ROSCHER, A.A.; METZGER, R.; GANTEN, D. et al.. Molecular cloning and functional characterization of a mouse bradykinin B1 receptor gene. Biochem. Biophys. Res. Commun., v. 220, p. 219-25, 1996.

PESQUERO, J. B.; ARAÚJO, R. C.; HEPPNTALL, P. A.; TUCKY, C. L.; SILVA, J. A.; WALTHER, T.; OLIVEIRA, S. M.; PESQUERO, J. L.; PAIVA, A. C. M.; CALIXTO, J. B.; LEWIN, G. R.; BADER, M. Hypoalgesia and altered inflammatory responses in mice lacking kinin B1 receptors. Proc. Natl. Acad. Sci., v. 97, n. 15, p. 8140-8145. 2000.

PETERS, C.; O'SHEA, K.S.; CAMPBELL,A.D.; WICHA, M.S.; LONG, M.W. Fetal expression of hemonectin: an extracellular matrix hematopoietic cytoadhesion molecule. Blood, v.75, p.357-64, 1990.

PRADELLES P, FROBERT Y, CREMINON C, LIOZON E, MASSE A, FRINDEL E. Negative regulator of pluripotent hematopoietic stem cell proliferation in human white blood cells and plasma as analysed by enzyme immunoassay. Biochem. Biophys. Res. Commun., v. 170, n. 3, p. 986-93, 1990.

QUITTERER, U.; LOTHER, H.; ABDALLA, S. AT1 receptor heterodimers and angiotensin II responsiveness in preeclampsia. Semin. Nephrol., v. 24, n. 2, p. 115119, 2004, Review.

REGOLI, D.; BARABÉ, J. Pharmacology of bradykinin and related kinins. Pharmacol., v. 32, n. 1, p. 1-46, 1980, Review. 
RHALEB, N.E.; PENG, H.; HARDING, P.; TAYEH, M.; LAPOINTE, M.C., CARRETERO, O.A. Effect of $\mathrm{N}$-acetyl-seryl-aspartyl-lysyl-proline on DNA and collagen synthesis in rat cardiac fibroblasts. Hypertension, v. 37 , n. 3 , p. 827-32, 2001.

RIEGER, K.J.; SAEZ-SERVENT, N.; PAPET, M.P.; WDZIECZAK-BAKALA, J.; MORGAT, J.L.; THIERRY, J.; VOELTER, W.; LENFANT, M. Involvement of human plasma angiotensin I-converting enzyme in the degradation of the haemoregulatory peptide N-acetyl-seryl-aspartyl-lysyl-proline. Biochem. J., v. 296, n. 2, p. 373-378, 1993

RIORDAN, J.F. Angiotensin-l-converting enzyme and its relatives. Genome Biol., v. 4, p. 225, 2003.

RODGERS, K.E.; XIONG, S.; STEER, R.; DIZEREGA, G.S. Effect of Angiotensin II on Hematopoietic Progenitor Cell Proliferation. Stem Cells, v. 18, p. 287-94, 2000.

ROUSSEAU-PLASSE A, LENFANT M, POTIER P. Catabolism of the hemoregulatory peptide N-Acetyl-Ser-Asp-Lys-Pro: a new insight into the physiological role of the angiotensin-1-converting enzyme N-active site. Bioorg. Med. Chem., v. 4, p. 11131119, 1996.

ROUSSEAU-PLASSE, A.; WDZIECZAK-BAKALA, J., LENFANT, M.; EZAN, E.; GENET, R.; ROBINSON, S. et al. Lisinopril, an angiotensin l-converting enzyme inhibitor, prevents entry of murine hematopoietic stem cells into the cell cycle after irradiation in vivo. Exp. Hematol., v. 26, p.1074-1079, 1998.

ROUSSEAU, A.; MICHAUD, A.; CHAUVET, M.T.; LENFANT, M.; CORVOL, P. The hemoregulatory peptide $\mathrm{N}$-acetyl-Ser-Asp-Lys-Pro is a natural and specific substrate of the N-terminal active site of human angiotensin-converting enzyme. J. Biol. Chem., v. 270, n. 8, p. 3656-61, 1995.

SABATINI, R.A. Regulação da atividade da enzima conversora de angiotensina I pelos receptores de cininas. $110 \mathrm{f}$. Tese (Doutorado Ciências Biológicas) - Biologia Molecular, Universidade Federal de São Paulo, São Paulo, 2006.

SALAMA, A.; MUELLER-ECKHARDT, C. Immune-mediated blood cell dyscrasias related to drugs. Semin. Hematol., v. 29, p. 54-63, 1992.

SCHOLKENS, B.A. Kinins in the cardiovascular system. Immunopharmacol., v. 33, p. 209-216. Review, 1996.

SKIDGEL, R.A.; ERDÖS, E.G. Angiotensin converting enzyme (ACE) and neprilysin hydrolyze neuropeptides: a brief history, the beginning and follow-ups to early studies. Peptides, v. 25, n. 3, p. 521-525, 2004, Review.

SKIDGEL, R.A.; ERDÖS, E.G. The broad substrate specificity of human angiotensin I converting enzyme. Clin. Exp. Hypertens. A., v. 9, n. 2-3, p. 243-59, 1987. Review. 
SPOONCER E, BROUARD N, NILSSON SK, WILLIAMS B, LIU MC, UNWIN RD, BLINCO D, JAWORSKA E, SIMMONS PJ, WHETTON AD. Developmental fate determination and marker discovery in hematopoietic stem cell biology using proteomic fingerprinting. Mol. Cell Proteomics, 2007 Dec 14 [Epub ahead of print]

STRAWN WB, RICHMOND RS, ANN TALLANT E, GALLAGHER PE, FERRARIO $\mathrm{CM}$. Renin-angiotensin system expression in rat bone marrow haematopoietic and stromal cells. Br. J. Haematol., v. 126, n. 1, p. 120-126, 2004.

SUGIYAMA, T.; YOSHIMOTO, T.; TSUCHIYA, K.; GOCHOU, N.; HIRONO, Y.; TATENO, T.; FUKAI, N.; SHICHIRI, M.; HIRATA, Y. Aldosterone induces angiotensin converting enzyme gene expression via a JAK2-dependent pathway in rat endothelial cells. Endocrinology, v. 146, n. 9, p. 3900-3906, 2005.

TAICHMAN, R.S.; REILLY, M.J.; MATTHEWS, L.S. Human osteoblast-like cells and osteosarcoma cell lines synthesize macrophage inhibitory protein 1alpha in response to interleukin 1 beta and tumour necrosis factor alpha stimulation in vitro. Br. $\mathbf{J}$. Haematol., v. 108, p. 275-83, 2000.

TAN, Y.; HUTCHISON, F.N.; JAFFA, A.A. Mechanisms of angiotensin Il-induced expression of B2 kinin receptors. Am. J. Physiol. Heart. Circ. Physiol., v. 286, n. 3, p. 926-932, 2004.

TRENTIN, J.J. Influence of hematopoietic organ stroma (hematopoietic inductive microenvironments) on stem cell differentiation. In: Gordon AS, ed. Regulation of Hematopoiesis. New York, NY: Appleton-Century Crofts, 1970. p. 161-170.

TOM, B.; DENDORFER, A.; DE VRIES, R.; SAXENA, P.R.; JAN DANSER, A.H. Bradykinin potentiation by ACE inhibitors: a matter of metabolism. Brit. J. Pharmacol., v. 137, p. 276-284, 2002.

TOM, B.; DENDORFER, A.; DANSER, A.H. Bradykinin, angiotensin-(1-7), and ACE inhibitors: how do they interact? Int. J. Biochem. Cell Biol., v. 35, n. 6, p. 792-801, 2003. Review.

UNGER, T. Blood pressure lowering and renin-angiotensin system blockade. J Hypertens. Suppl., v. 21, Suppl 6, p. S3-7, 2003.

van BRUMMELEN, P.; WILLEMZE, R.; TAN, W.D.; THOMPSON, J. Captoprilassociated agranulocytosis. Lancet, v. 1, n. 8160, p. 150, 1980.

VERFAILLIE, C.M. Adhesion receptors as regulators of the hematopoietic process. Blood, v. 92, p. 2609- 2612, 1998.

VERFAILLIE, C.M. Soluble factor(s) produced by human bone marrow stroma increase cytokine-induced proliferation and maturation of primitive hematopoietic progenitors while preventing their terminal differentiation. Blood, v. 82, p. 2045-2053, 1993. 
VIO, C.P.; JEANNERET, V.A. Local induction of angiotensin-converting enzyme in the kidney as a mechanism of progressive renal diseases. Kidney Int. Suppl., v. 86, p. S57-63, 2003.

WDZIECZAK-BAKALA, J.; FACHE, M.P.; LENFANT, M.; FRINDEL, E. SAINTENY, F. AcSDKP, an inhibitor of CFU-S proliferation, is synthesized in mice under steadystate conditions and secreted by bone marrow in long-term culture. Leukemia, v. 4, n. 3, p. 235-237, 1990.

WEISS, L.; GEDULDIG, U. Barrier cells: stromal regulation of hematopoiesis and blood cell release in normal and stressed murine bone marrow. Blood. v. 78, n. 4, p. 975-990, 1991.

WHETTON, A.D.; SPOONCER, E. Role of cytokines and extracellular matrix in the regulation of haemopoietic stem cells. Curr. Opin. Cell Biol., v. 10, n. 6, p. 721-726, 1998, Review.

ZUCKERMAN, K.S.; WICHA, M.S. Extracellular matrix production by the adherent cells of long-term murine bone marrow cultures. Blood, v. 61, n. 3, p. 540-547, 1983. 
Tabela 1: Número de células não-aderentes (viáveis) obtido na $5^{\mathrm{a}}$ e $6^{\mathrm{a}}$ semanas de cultivo e coletadas do sobrenadante das CLLD obtidas a partir de células da medula óssea de animais WT $(n=5)$. As culturas foram tratadas com AcSDKP $(1 \eta \mathrm{M})$ e captopril $(1 \mu \mathrm{M})$. O meio saturado foi trocado semanalmente contendo os compostos acima e suas respectivas concentrações. $\left({ }^{*}\right)$ Significativo em relação ao controle (salina) $(P<0.05$ - ANOVA; Tukey-Kramer).

\begin{tabular}{|c|c|c|c|}
\hline \multirow{2}{*}{ Semanas } & \multicolumn{3}{|c|}{ Número de células hematopoéticas $\left(\times 10^{5}\right)$} \\
\hline & Controle & AcSDKP & Captopril \\
\hline $5^{\mathbf{a}}$ & $22,7 \pm 2,00$ & $16,8 \pm 2,40^{*}$ & $15,1 \pm 1,64^{*}$ \\
\hline $6^{a}$ & $16,4 \pm 2,58$ & $10,4 \pm 1,81^{*}$ & $8,20 \pm 1,48^{*}$ \\
\hline
\end{tabular}

Tabela 2: Número de células não-aderentes (viáveis) obtido na $5^{\mathrm{a}}$ e $6^{\mathrm{a}}$ semanas de cultivo e coletadas do sobrenadante das CLLD obtidas a partir de células da medula óssea de animais KOB1 $(n=5)$. As culturas foram tratadas com AcSDKP $(1 \eta \mathrm{M})$ e captopril $(1 \mu \mathrm{M})$. O meio saturado foi trocado semanalmente contendo os compostos acima e suas respectivas concentrações. $\left(^{*}\right)$ Significativo em relação ao controle (salina) $(P<0.05$ - ANOVA; Tukey-Kramer).

\begin{tabular}{|c|c|c|c|}
\hline \multirow{2}{*}{ Semanas } & \multicolumn{3}{|c|}{ Número de células hematopoéticas $\left(\times 10^{5}\right)$} \\
\hline & Controle & AcSDKP & Captopril \\
\hline $5^{a}$ & $24,0 \pm 2,08$ & $22,2 \pm 3,56$ & $16,8 \pm 2,28 *$ \\
\hline $6^{a}$ & $18,2 \pm 2,94$ & $11,2 \pm 1,92^{*}$ & $9,40 \pm 1,14^{*}$ \\
\hline
\end{tabular}

Tabela 3. Número de CFU-GM obtido do sobrenadante das culturas líquidas de longa duração de animais WT e tratadas semanalmente com AcSDKP (1nM) e captopril $(1 \mu \mathrm{M})$. Os resultados foram obtidos após a $5^{\mathrm{a}}$ semana. As culturas 
foram repopuladas na $4^{a}$ semana de incubação. ( $\left.{ }^{*}\right)$ Significativo em relação ao controle (salina) $(p<0,05$ - ANOVA; Tukey-Kramer)

\begin{tabular}{lcc}
\hline & \multicolumn{2}{c}{ Número de CFU-GM / Frasco (WT) } \\
\cline { 2 - 3 } & $5^{\text {a }}$ semana & $6^{\text {a }}$ semana \\
\hline Controle & $931 \pm 123$ & $369 \pm 58,6$ \\
AcSDKP & $729 \pm 82,1^{*}$ & $198 \pm 47,5^{*}$ \\
Captopril & $731 \pm 50,1^{*}$ & $214 \pm 33,1^{*}$ \\
\hline
\end{tabular}

Tabela 4. Número de CFU-GM obtido do sobrenadante das culturas líquidas de longa duração de animais KOB1 e tratadas semanalmente com AcSDKP (1nM) e captopril $(1 \mu \mathrm{M})$. Os resultados foram obtidos após a $5^{a}$ semana. As culturas foram repopuladas na $4^{\mathrm{a}}$ semana de incubação. $\left.{ }^{*}\right)$ Significativo em relação ao controle (salina) $(p<0,05$ - ANOVA; Tukey-Kramer).

\begin{tabular}{lcc}
\hline & \multicolumn{2}{c}{ Número de CFU-GM / Frasco (KOB1) } \\
\cline { 2 - 3 } & $5^{\text {a }}$ semana & $6^{\text {a }}$ semana \\
\hline Controle & $904 \pm 66,8$ & $400 \pm 57,2$ \\
AcSDKP & $793 \pm 82,3$ & $270 \pm 50,6^{*}$ \\
Captopril & $818 \pm 83,4$ & $320 \pm 41,8$ \\
\hline
\end{tabular}

Tabela 5: Níveis de AcSDKP no meio condicionado de CLLD tratadas com salina (controle). O tratamento das culturas foi realizado semanalmente juntamente com a troca por meio fresco. O meio condicionado foi coletado na última semana de tratamento. Foi quantificado tanto o AcSDKP extracelular como o intracelular. 
Níveis de AcSDKP - Salina

Animais

Medula óssea - Intracelular Medula óssea - Extracelular (pmol/g proteína)

$(p m o l / m L)$

WT

$0,007 \pm 0,0023$

$0,72 \pm 0,19$

KOB1

$0,006 \pm 0,0020$

$0,80 \pm 0,28$

Tabela 6: Níveis de AcSDKP no meio condicionado de CLLD tratadas com captopril $(1 \mu \mathrm{M})$. $O$ tratamento das CLLD foi realizado semanalmente juntamente com a troca por meio fresco. O meio condicionado foi coletado na última semana de tratamento. Foi quantificado tanto o AcSDKP extracelular como o intracelular. ( $\left.{ }^{*}\right)$ Diferenças significativas em relação ao controle $(P<0.05)$. ANOVA, Tukey-Kramer. (\#) Diferença significativa em relação ao controle e ao WT e KOB2 $(P<0.05)$. ANOVA, Tukey-Kramer.

\begin{tabular}{ccc}
\hline & \multicolumn{2}{c}{ Níveis de AcSDKP - Captopril } \\
\cline { 2 - 3 } Animais & $\begin{array}{c}\text { Medula óssea - Intracelular } \\
(\text { pmol/g proteína })\end{array}$ & $\begin{array}{c}\text { Medula óssea - Extracelular } \\
(p m o l / m L)\end{array}$ \\
\hline WT & $0,014 \pm 0,0050$ & $4,93 \pm 1,46$ \\
KOB1 & $0,011 \pm 0,0061$ & $3,31 \pm 1,56 \#$ * \\
\hline
\end{tabular}

Tabela 7: Lista dos conjuntos de sondas e primers utilizados na reação de RT-PCR em tempo real. 
Recptor B1

Receptor B2

ECA

B-actina sonda 5'-CACAGGAACCCAGACAG-3' sense 5'-CCATACAAAACCCCAGCTGAA-3' anti-sense 5'-CTTTGGTTAGAAGGCTGTAGCTTCA-3'

sonda 5'-CCGCCACTGGAGAAC-3'

sense 5'-CCCTTCCTCTGGGTCCTCTT-3'

anti-sense 5'-GAAGAACACGCTGAGGACAAAGA-3'

sonda 5'- CTCAGCCTGGGACTTCTACAAC-3 ' sense 5'- GGAGACGACTTACAGTGTAGCC- 3' anti-sense 5'- CTCCATGTTCACAGAGGTACACT-3'

sonda 5'- CTGATCCACATCTGCT-3' sense 5'- CTGGCCTCAACTGTCCACCTT-3', anti-sense 5'- CGGACTCATCGTACTCCTGCTT-3', 